Illinois State University

ISU ReD: Research and eData

Theses and Dissertations

$11-2-2013$

\title{
Identifying with the Help: an Examination of Class, Ethnicity and Gender on a post-Colonial French Houselot
}

Erin Nicole Whitson

Illinois State University, enwhitson@yahoo.com

Follow this and additional works at: https://ir.library.illinoisstate.edu/etd

Part of the History of Art, Architecture, and Archaeology Commons

\section{Recommended Citation}

Whitson, Erin Nicole, "Identifying with the Help: an Examination of Class, Ethnicity and Gender on a postColonial French Houselot" (2013). Theses and Dissertations. 62.

https://ir.library.illinoisstate.edu/etd/62

This Thesis is brought to you for free and open access by ISU ReD: Research and eData. It has been accepted for inclusion in Theses and Dissertations by an authorized administrator of ISU ReD: Research and eData. For more information, please contact ISUReD@ilstu.edu. 


\section{IDENTIFYING WITH THE HELP: AN EXAMINATION OF CLASS, ETHNICITY AND GENDER ON A POST-COLONIAL FRENCH HOUSELOT}

Erin N. Whitson

118 Pages

December 2013

The purpose of this study is to attempt to analyze and interpret an outbuilding located in Ste. Genevieve, Missouri, a town established by French settlers in the 1780s. First the functional activities associated with the outbuilding will be determined and examined to best understand where and how the structure fit within the larger property. The activities taking place within/outside the outbuilding-especially those linked to domestic chores - will theoretically paint a clearer picture of who was living and/or working within the structure and who was not. Since little work has been done within the French Mississippi River valley on outbuildings in general, and slaves/servants more specifically, and since much of the existing documentation concerns the main house families, this study will aid in filling some of the gaps in our knowledge about where domestically oriented outbuildings, and their residents, fit within the social structure of communities like Ste. Genevieve, Missouri. Questions focusing on three aspects of identity-class, gender, and ethnicity-will aide in better understanding the social dynamics between the community's residents - for both the owners and the 
"help" living on the Janis-Ziegler houselot. As will be discussed later in this study, the material culture recovered from the outbuilding and the property will show a connection to people other than the property owners and will answer the questions concerning the "help" and the social dynamics of those (both the owners and the owned/hired) living on the Janis-Ziegler property. 
IDENTIFYING WITH THE HELP: AN EXAMINATION OF CLASS, ETHNICITY

AND GENDER ON A POST-COLONIAL FRENCH HOUSELOT

ERIN N. WHITSON

\author{
A Thesis Submitted in Partial \\ Fulfillment of the Requirements \\ for the Degree of \\ MASTER OF SCIENCE \\ Department of Sociology and Anthropology \\ ILLINOIS STATE UNIVERSITY
}

2013 
IDENTIFYING WITH THE HELP: AN EXAMINATION OF CLASS, ETHNICITY AND GENDER ON A POST-COLONIAL FRENCH HOUSELOT

ERIN N. WHITSON

COMMITTEE MEMBERS:

Elizabeth M. Scott, Chair

Kathryn Sampeck 


\section{ACKNOWLEDGEMENTS}

First I would like to thank those on my committee for always being there with suggestions and advice whenever I felt too insecure or unsure of my abilities. Dr. Scott, without you and your uplifting attitude...as well as your one-step-at-a-time approach...I would have been lost long ago...you've been generous in time, energy, and knowledge and I am very glad to have had the chance to work with you. Dr. Sampeck, I more than appreciate the support you've given me...both in the writing of my thesis and in my academic journey...more than that, you've taught me to look beyond the apparent "pristine landscapes" to see deeper connections that aren't always apparent right away. Thank you both for being patient with me and for always being ready to teach me to slay dragons instead of slaying them for me.

I would also like to gratefully thank many other professors from both Illinois State University and Lindenwood University who have helped me along my chosen path (you know who you are). Without the support from these individuals, both in and out of the classroom, I fear that I would have had a much less vibrant experience while working on my Master's degree.

Thirdly, I would like to thank the men and women that had the most to do with keeping me grounded, sane, and laughing maniacally during my time at Illinois State University: my cohort. From day one, my cohort has proved to be full of some of the 
best friends that I have ever known. Be it with tears, laughter, anger, or words of commiseration they have been there to share and laugh along the way. They've always been my critical, though open minded, audience (something I desperately needed at times) and they were instrumental in helping me to become a better-rounded and steady academic and individual. And for those working with me in Dr. Sampeck's labDave Watt, Valerie Hall, and Alison Hodges-I count you in this category as well...you were all life and sanity-savors...thank you greatly!

The last set of thank yous I would like to extend go, of course, to my family. I want to thank them for sitting through long (probably boring and repetitive) ramblings on my part about "interesting aspects" of my classes, work, or thesis. They did so with only slightly glazed looks on their faces and nods to let me know that they still listened.... which I appreciated. Thank you Mom for always understanding and pushing me to leave the nest and seek wider worlds. Special thanks should also go to my brother who's known for simply telling me to "do it" like the only thing holding me back is me. To the rest, also-you have encouraged me, listened to me cry, laughed with me, and kept me humble. Whereas those listed earlier helped to shape me as a student and scholar, my family molded me to become the person I am today. Thank you for that. As the saying goes, it takes a village to raise a child. Though not a child in the traditional sense when I first came to Illinois State University, I was young in my understanding of the world, my field of choice, and myself. Without my "village" of professors, friends, and family I would have not succeeded in getting as far as I have. 
That being said, there were several (most likely) I will have failed to mention. For those not mentioned, I apologize and fully intend for this acknowledgment to extend to you as well.

E.N.W. 


\section{CONTENTS}

\section{Page}

ACKNOWLEDGEMENTS

CONTENTS

TABLES

FIGURES

CHAPTER

I. INTRODUCTION

Questions to be Addressed

Review of the Scholarly Literature

French Colonial Archaeology

The Archaeological Study of Ste. Genevieve

Theoretical Framework

Class

Ethnicity

Summary

The Janis Occupation 
Slavery and African Slaves within the Illinois Country 28

Ste. Genevieve $\quad 34$

The Janis-Ziegler House $\quad 36$

Summary 40

III. METHODOLOGY 41

$\begin{array}{ll}\text { Summary } & 47\end{array}$

$\begin{array}{ll}\text { IV.ANALYSIS } & 48\end{array}$

The Outbuilding Assemblages 49

Comparison with the Main House 65

$\begin{array}{ll}\text { Summary } & 81\end{array}$

V. CONCLUSION AND RECOMMENDATIONS FOR FUTURE RESEARCH 83

$\begin{array}{ll}\text { Recommendations for Future Research } & 87\end{array}$

$\begin{array}{ll}\text { REFERENCES } & 91\end{array}$

APPENDIX: $\quad$ Comprehensive Tables Listing Artifacts 102 
3.1 Data Table 3.1 List of Functional Categories and their Gendered Associations.

4.1 Data Table 4.1 Artifact Quantities and Percentages from the Outbuilding by Occupation.

4.2 Data Table 4.2 Architectural Remains from the Outbuilding by Occupation.

4.3 Data Table 4.3 Artifact Quantities and Percentages from the Outbuilding by Occupation, with Architectural, Animal

4.4 Data Table 4.4 Functional Categories for the Outbuilding without Construction and Maintenance, Animal Remains, Plant Remains, and Unidentified.

4.5 Data Table 4.5 Economic scales associated with Ceramics for the Outbuilding.

4.6 Data Table 4.6 A Comparison in Percentages of Artifact Materials in the Outbuilding.

4.7 Data Table 4.7 Functional Categories with Gendered Associations from the Outbuilding by Occupation, with all Categories concerning Ceramics Represented by Minimum Number of Vessels.

4.8 Data Table 4.8 Gender Representations by Functional Activity Associated Artifacts per Occupation in/around the Outbuilding. 
4.9 Data Table 4.9 Janis and Ziegler Occupations for both the Outbuilding and Main House.

4.10 Data Table 4.10 Functional Categories for the Main House with Construction and Maintenance, Animal Remains, Plant Remains, and Unidentified Removed (categories that Represent Ceramics are tallied as Minimum Number of Vessels).

4.11 Data Table 4.11 Functional Categories for both the Main House and the Outbuilding (Ceramics Represented as Sherd Counts) with Animal Remains, Plant Remains, Construction and Maintenance and Unidentified related Artifacts Removed.

4.12 Data Table 4.12 Economic scales associated with Ceramics Within both the Janis and Ziegler Occupations for both the Outbuilding and Main House.

4.13 Data Table 4.13 Artifact Quantities and Percentages by Occupation for the Main House.

4.14 Data Table 4.14 Functional Categories with Gendered Associations from the Main House by Occupation, with all Categories concerning Ceramics Represented by Minimum Number of Vessels.

4.15 Data Table 4.15 A More Condensed Version of Table 4.14. 


\section{FIGURES}

Figure

1. Janis-Ziegler House, Ste. Genevieve, Missouri.

2. Photograph of the Janis-Ziegler Property c. $1880 \mathrm{~s}$

Illustrating the Concept of an Urban Farmstead. Photo courtesy of the Missouri Historical Society, St. Louis, Missouri.

3. Image of Feature 7 (Post Molds from the Outbuilding).

Photograph taken by Richard Young.

4. Image Illustrating Miller's $3^{\text {rd }}$ Economic Level Based off of Ceramic used by the Janis family. Hand-Painted Pearlware Bowl. Photograph taken by Dr. Elizabeth M. Scott.

5. Image Illustrating Miller's $3^{\text {rd }}$ Economic Level Based off of Ceramic used by the Janis family. Hand-Painted Pearlware Bowl. Photograph taken by Dr. Elizabeth M. Scott. 


\section{CHAPTER I}

\section{INTRODUCTION}

The purpose of this study is to attempt to analyze and interpret an outbuilding located in Ste. Genevieve, Missouri, a town established by French settlers in the 1780s. First the functional activities associated with the outbuilding will be determined and examined to best understand where and how the structure fit within the larger property. The activities taking place within/outside the outbuilding-especially those linked to domestic chores-will theoretically paint a clearer picture of who was living and/or working within the structure and who was not. Since little work has been done within the French Mississippi River valley on outbuildings in general, and slaves/servants more specifically, and since much of the existing documentation concerns the main house families, this study will aid in filling some of the gaps in our knowledge about where domestically oriented outbuildings, and their residents, fit within the social structure of communities like Ste. Genevieve, Missouri. Questions focusing on three aspects of identity - class, gender, and ethnicity - will aide in better understanding the social dynamics between the community's residents - for both the owners and the "help" living on the Janis-Ziegler houselot. As will be discussed later in this study, the material culture recovered from the outbuilding and the property will show a 
connection to people other than the property owners and will answer the questions concerning the "help" and the social dynamics of those (both the owners and the owned/hired) living on the Janis-Ziegler property.

\section{Questions to be Addressed}

The primary questions I would like to address are: what is the occupational sequence and purpose associated with the outbuilding on the Janis-Ziegler property? Who might have been living and/or working in the outbuilding? According to Hawkins (2007), at the time the Zieglers bought the property in 1833 , there were several outbuildings present. Assuming that the outbuilding in question was one of the ones recorded in the bill of sale, did the utilization of the building change with the change in ownership of the property? Is there a change through time in the occupants of the structure that can be correlated with the change in ownership of the property?

Ekberg (1996:432) noted that reports in 1789 have Nicolas Janis and his family bringing up to nineteen slaves with him to Ste. Genevieve. Two years later, according to a census conducted by the Spanish government (Houck 1909:367), the Janis family had ten slaves living on their property. Regardless of numbers, the Janis family owned slaves while they occupied the site from the late 1700 s and early 1800 s. Later when the German Ziegler family moved onto the property, they had Irish, and German immigrants working for them as servants. Can archaeological material recovered from this portion of the stratigraphic layer associated with the Ziegler family help determine class and possibly ethnic differences among the people living on the property at the time? 
It would be particularly interesting, also, to compare the assemblages from the main house on the property and the outbuilding to see what class differences might make themselves apparent between the family in control of the property and those working as slaves or servants.

Each of the groups represented at the site has its own ethnic background, which is made up of such distinctive parts of daily life as architecture, language, religious belief systems, material culture and the mobility they have (or do not have) within the social hierarchy. The material culture associated with these groups may be more difficult to pursue because they exist in a time of a great industrialized production of goods. Greene (2011:70) suggests that archaeologists studying the eighteenth century (and earlier) may have greater ability to identify ethnic markers than those researching sites from nineteenth-century settings because of the consumer's ability later on to buy mass-produced metal, glass, and ceramic wares.

Material culture can be a difficult thing to study, but it can also speak deeply about the identity of those who bought, used, and discarded the things found through archaeological excavations. Not only can it give researchers possible signs pointing to ethnic identities and the interactions therein, but it can also provide glimpses into the ideological shifts taking place within a society (Dethlefsen and Deetz 1966) as well as provide a way to show insights into the capitalistic environment (both on small and large scales) of the times in question (Wolf 1997). "The underlying premise" of material culture, "is that objects made or modified by man reflect, consciously or unconsciously, directly or indirectly, the beliefs of individuals who made, commissioned, purchased, or 
used them, and by extension the beliefs of the larger society to which they belonged" (Prown 2008: 1-2). "When people engage in various activities, their actions reflect individual choice as well as the norms and expectations of the broader society. The set of choices is restricted by the available materials and by the assessed set of options for an individual, which, in turn, is constrained by diverse lines of identity, such as gender, ethnicity/race, class/status, and so on" (White and Beaudry 2009:212).

\section{Review of the Scholarly Literature}

\section{French Colonial Archaeology}

Work on French colonial sites in North America has, according to Waselkov (1997:12) "followed one of three principal tacks: the search for Great Men, a fascination with military sites-i.e., forts and battlefields, and a strong interest in American Indian sites that contained French artifacts. " French colonial domestic sites have met with few investigations. Like Waselkov (1997:12), Mazrim (2010:150) also notes that "most of the excavations conducted on seventeenth- and eighteenth-century sites focused on Native American villages or French fortifications, not single-family dwellings." It should not be a surprise than, that if less archaeological work has been completed on the main family homes, less still has been done on French colonial outbuildings within the bounds of the Illinois Country.

In 2011, Mazrim, one of the few researchers interested in the French colonial phase within the region, published a book discussing a selection of French colonial domestic sites. There is some chronological cross-over between the sites within Mazrim's book (2011) and the one associated with the Janis-Ziegler property, but the 
sites most examined by Mazrim are from earlier periods of French interaction within the region and are all located to the east of the Mississippi River. Though he seldom discusses the outbuildings associated with the domestic sites, other than to note their probable existence, Mazrim, acknowledges that French properties within the region often included, "a main dwelling, and a series of outbuildings, including barns, stables, hen houses, and sometimes slave quarters" (2007:54).

Other researchers to have made a dint in the vastly under-researched study of the French colonial Midwest have investigated a wide variety of topics within the region. These include Creole architecture in upper and lower Louisiana and Saint Domingue (Edwards 2006), protohistoric tribes and their interactions with the French in the Illinois country (Ehrhardt 2010), documents and archaeology in French Illinois (Kimball-Brown 1991), domestic dining at French colonial sites in the American Bottom (Kuehn 2010), colonization at Saline Creek Valley in Missouri (Trimble et al. 1991), faience in French Colonial Illinois (Walthall 1991) and the archaeology completed at French colonial Cahokia in present-day Illinois (Gums 1988).

The Archaeological Study of Ste. Genevieve

Seven archaeological investigations have been made in Ste. Genevieve, Missouri. These include F. Terry Norris's 1991 survey of Vieux (old) Ste. Genevieve next to the Mississippi River. Norris confirmed the site of the earlier settlement (1750s-1780s), through systematic pedestrian survey. Another archaeologist to have made a significant dint into historic Ste. Genevieve was Kit W. Wesler who from 1997 to 1999 examined three sites - the Delassus-Kern house, the Felix Vallé house, and the Benjamin Shaw 
house (Wesler 1999, 2004, 2005) during the transition period (French to Spanish to American). Elizabeth M. Scott conducted Illinois State University field investigations at both the Bequette-Ribault house in 2004 and 2005 and the Janis-Ziegler house, starting in 2006 and continuing to the present time. Meredith Hawkins (2007) and Matthew A. Cox (2009) both completed Master's thesis projects on the Janis-Ziegler site.

\section{Theoretical Framework}

\section{Class}

Marxist perspectives, with their concern for social inequalities, will be of particular assistance in fleshing out answers to disparities in the material culture of those who lived and/or worked in the outbuilding compared to those living and working in the main house. Though Marxist theory will shed less light on what the outbuilding in question was used for, it will aid in answering those questions linked to identity. Marxist theory will be used in this project, not only in gaining a better understanding of the class structure of those living and working at the Janis-Ziegler site, but it will also make clearer how other social factors, such as gender and possibly ethnicity, played a part in the social order of life (Wright 1996) in the early post-colonial Midwest. The JanisZiegler house presents an interesting case study investigating the impacts of the interactions of multiple groups (divisible via class, ethnicity and gender) over multiple generations on the material culture in two distinct areas on the same property.

Within the capitalistic system in place on the North American continent both before and after American ownership, slavery affected those on both sides of the 
ownership lines on many levels. Race is a contributing factor to social placement as

Orser (2007:45) writes:

"The idea that racial categorization has concrete material dimensions - that it relates to access to goods and services - raises the issue of social class. The issue of class may seem to move the discussion away from race and toward economics, but class is an entangled vector of inequality that must be confronted in any consideration of racialization in the United States.

Marxism, as an archaeological social theory, has been examined by a multitude of researchers from many points of view and in many different fashions. Eric R. Wolf is perhaps one of the most comprehensive writers on the rise and influence of capitalism on world history (large scale effects of capitalism). He approaches Marxism from a cultural perspective, showing how the system tends to propagate into new regions and how it can be traced on many different scales. He, like many other prominent researchers (McGuire and Reckner 2002; Orser 1996; Paynter 1988) focuses on how capitalism spread and affected various scales in the mass-production of material goods from the late eighteenth century to the twentieth.

There is some debate, however, in historical archaeology, about whether economic status and race/ethnicity should be linked together in trying to find answers to identity (MacSweeny 2009). Orser contends that the "linkage of race and class is obvious in the United States" (Orser 2007:46), that the two, used together, provide a better understanding of the identities in question. Stephen A. Brighton (2011:31) sums up the situation by writing, "studies of material culture must include the realities of inequality and alienation from the economic, political, and social structure. The varying levels of inequalities are built upon values of difference (real or imaginary) fostering social and 
economic divisions, and one's position in the social hierarchy dictates the degree of advantages or depravations in the quality of life."

African slaves in the French colony in the Illinois Country have received little scholarly attention. They undisputedly fell within a racial and class classification within their social environment and were negatively affected by that. People represent themselves to those around them via material culture and behavior, so theoretically there should be some type of material representation that marks them as unique. The material artifacts often associated with slave contexts include colonowares (also called Afro-Caribbean ware) (Armstrong 1999; Ferguson 1991), beads of all colors, though many draw more significance from blue colored ones (Armstrong 1990; Asher and Fairbanks 1971; Handler et al. 1979; Stine et al. 1996; Yentsch 1994), and hollowwares (Greene 2011).

Since historical archaeologists turned their attention from studying only the elite, white, males and their settings to a broader array of subjects, much work has been undertaken on enslaved Africans in numerous contexts around the world. Researchers working on sites ranging from the Caribbean, the American South, and Latin America prove the geographical diversity inherent in slave archaeology (Armstrong 1999; Delle 2008; Edwards-Ingram 2001; Epperson 1999; Ferguson 1991; Heath 1999b; Kelly 2004; Mrozowski et al. 2008; Orser 1998; Paynter 2001; Stine et al. 1996; Samford 2004; Weik 2004). The research completed in such sites includes, but is not limited to studies dealing in material culture (Deetz 1977; Ferguson 1980, 1991; Handler and Lange 1978; Otto 1984; Stine et al. 1996), landscape (Armstrong 1999; Epperson 1999), gender 
(Samford 2004), class interactions (Deetz 1977; Leone 1984), medicines (EdwardsIngram 2001; Mrozowski et al. 2008), the African Diaspora (Armstrong 1999; Kelly 2004; Orser 1998; Weik 2004) modernity (Delle 2008), and slave quarters (Clites 2009; Ferguson 1991; Young 1999). An interesting aspect to most, if not all of these studies is how these enslaved individuals interact in the areas to which they and their ancestors had been moved, and how they interjected their own agency into their situations. The ethnic interactions that took place on the Janis-Ziegler property will be examined through the lens of material culture and Marxism to provide a better understanding of the relationship, at different times, of the owners of the property and those who involuntarily and voluntarily worked for them.

\section{Ethnicity}

Orser writes (2007:8), "at its most basic, race is a label imposed from the outside by people who classify themselves as nonmembers of a racial group." "Ethnic affiliation," he continues, "is self imposed from the inside" (Orser 2007:8). Ethnicity can depend on a multitude of factors, from a person's age to his/her religious background to the language he/she speaks or the geographic region he/she grew up in. In other words, ethnicity stems from the individual's "willingness to join the group" (Orser 2007:8) whereas a person's race is an external, usually incontestable designation that places them lower in the social stratification than those who placed the designation upon them.

Franklin and Fesler (1999:3) write:

"Instead of searching for the static patterns and correlates of so-called ethnic identity [what early researchers did], we must recognize that ethnicity and ethnic identity served as a dynamic agent of social and cultural negotiation. All peoples and the objects 
through which they manipulate daily life are imbued with ethnic overtones, whether it be in the meals they consume, the clothing they wear, or the spaces they inhabit."

Audrey J. Horning, John Metz and Carl Steen (Horning 1999, Metz 1999, Steen 1999) examine the "role of power in the creation of ethnic groups" because as Horning relays, "ethnic groups, by definition, only exist because of their relationships with other groups" (Horning 1999:121). Barbara Heath (1999a) looks at how people represent their ethnicity to the world around them in their clothing and adornment and she was able to interject aspects of identity such as gender and occupation in her study as well, showing that the three concepts (ethnicity, gender, and class) can be intricately linked and can all be used to better understand the identities of those being studied.

A pattern I found in looking at the scholars above was their refusal to simply lay ethnicity out in terms of identifying ethnic markers. Some of these researchers use ethnic markers as links in ethnic patterns, but they also look at ethnicity through the interrelations and power structures between the people inside the group and those outside the group. Regardless of whether an individual is lumped within a racial or ethnic category, these associations can determine, at least at times, the individual's position within his/her social sphere. Thus, it can be incredibly helpful, in the case of the JanisZiegler outbuilding, to determine the residents' placement within the racial/ethnic categories with which they would have been associated.

Other researchers have examined social organization by trying to understand how a person's identity - how one sees oneself or is seen by others - affects his/her placement within the social stratification of the time (Delle 2001; Edwards-Ingram 2001; 
Epperson 2001; Fesler and Franklin 1999; Franklin 2001; Heath 1999; Horning 1999;

Kern 1999; Matthews 2001; Metz 1999; Mullins 2001; Neiman 1999; Orser 2001;

Paynter 2001; Leone and Fry 2001; Samford 1999; Singleton 2001; Steen 1999; Wilkie

2001). Scott (2001a), for example, has looked at ethnicity through foodways to better understand the relationship between slaves and their masters at Nina plantation on the banks of the Mississippi River.

Through past researchers, we know that the Janis family moved into Ste. Genevieve with slaves of their own in a society where slave ownership was acceptable as well as a viable manner in which to display wealth and social class. The Ziegler family on this property did not own slaves, but employed Irish, and German servants. There may theoretically be some aspects of material culture with which these groups were more inclined to associate. For example, Baumann et al. (2008:77) suggest that lead glazed redwares may be an ethnic marker for Germans in St. Louis in the nineteenth century. Not only is this type of ceramic generally associated with those of German descent, the forms that the vessels take may also show ethnic traditions, practices and foodways. Groover (2003:258) also indicates that redwares tended to be produced and utilized more often by German individuals or those of German descent, but Groover (2003:258), Baumann et al. (2011:77), and Zug (1986:3-26) all warn also, that though the German-based groups seemed to produce more of the ceramic than many others, they were not the sole users or makers of the product.

Another way in which ethnicity and/or race may present a challenge in studying the Janis-Ziegler outbuilding is in the social change and adaptation that the various 
ethnic groups may have made while living on the property. Brighton (2011) indicates that to adapt quicker into the American social sphere and to gain more mobility therein, the Irish often adopted a more American approach to consumerism, and Elliott and Elliott (2000) found similar results with their research with Germans in the Carolinas. In Brighton's example, the Irish began to do as their native-born contemporaries did by acquiring more specialized stemwares and servingwares so they could more seamlessly blend in with their Victorian American neighbors who were also making a similar adjustment.

Gender

"If gender is culturally constructed," writes Voss (2006), "then it also has a history, and the history of gender roles, symbols, and identities is central to understanding the social and political organization of any society." Gender, though very much an integral part of understanding how and where people fit into their own societies, has not been a prominent-if seen at all-part of archaeological theory until relatively recently. Voss (2006:108) writes that the "emergence of gender studies in archaeology is widely attributed to the publication of "Archaeology and the Study of Gender"'" by Conkey and Spector in 1984. "By the late 1980s, workshops and conferences brought together researchers interested in integrating archaeology, feminist theory, women's studies, and the interpretation of a gendered past" (Voss 2006:108). Despite being a fairly new interest within the field of archaeology, the archaeology of gender has broached wide ranging and diverse aspects of the human experience around the globe. From prehistoric to historic contexts, gender has aided in 
understanding the dynamics between men/women (culturally defined) and male/female (biologically defined) figures. Spector (1993) used gender in her research of the Wahpeton Dakota in Little Rapids, Minnesota by using a task differentiation framework. This framework "uses historical evidence to develop models of which artifacts, structures, and facilities are likely to have been associated with men or women in a given culture" (Voss 2006:109). She used this framework to study change-instigated by the nineteenth-century fur trade-over time. Spector also used an "empathetic" interpretation technique meant to place the reader/researcher in the proverbial shoes of the (in this case) women using the tools recovered from archaeological excavation. She illustrates with an awl how archaeological interpretation can enrich the simplest of tools into vehicles or symbols of social position within that society. Voss (2006:111) writes that within engendered archaeology, there are "four key topics where studies of gender have become central to research in historical archaeology: research on colonization, Victorian America, the African diaspora, and institutions."

Kathleen Deagan (1983) illustrates how gendered archaeology can illuminate aspects of indigenous traditions being employed in colonial settings through her excavations at the María de la Cruz site, where she found the women-in this case almost solely Indian women - were able to preserve at least a portion of their traditional ways of life through the preparation and use of traditional cooking wares and foods. A few of the researchers interested in gender who have examined gender in colonial settings include: Jackson (1994), Starbuck (1994) and Scott (1991, 2001b) among many others. 
Diana Wall (1994) studied the nineteenth-century New York City domestic sphere to see if life in the home was changing to reflect changing gender roles within contemporary society. She found that ceramics used to serve food became less about food service and consumption and more about the women of the home using food and ceramics as a means of projecting the family image and reinforcing and/or bettering the family standing within local networks. "Women," Wall (1994:149) writes, "must be regarded as active agents in the redefinition of gender."

The third manner in which gender is often represented within historical archaeology is in studies of the African diaspora. Maria Franklin (2001) explores "soul food' as an expression of African-Virginian culture and identity."

Wilkie (2000) uses archaeological explorations of gender to examine medicine on the Oakley Plantation in Louisiana and its shift from "homemade teas and tinctures to commercially available patent medicines. The patent medicines chosen by Oakley's residents were compatible with traditional healing practices, suggesting a substitution in materials but a continuation of traditional cosmology" (Voss 2006:115).

The study of institutions and gender dynamics has been used to illustrate resistance. Casella (2000), in her investigation of female factories (prisons) in Australia, concluded "that the doctrines of femininity and reform espoused through the Factory's architecture were subverted by social and sexual networks among the convict women" (quoted in Voss 2006:117).

Census records as well as past investigations of the site have shown the presence of both men and women in both the main structure and within the work force living on 
the property. We know that men and women spent time in and around both structures (the main house and the outbuilding) through the activities taking place in the immediate vicinity of both, as seen through the material culture recovered (See Appendix). Using gender to examine change over time will help present a better understanding of how roles between genders fluctuate or stay the same between the French and the German/American occupations. The artifact concentrations outside the outbuilding and the main house will also indicate activity areas as well as possibly specific gendered and class based uses of space. Gibb and King (1991) illustrates how gender plays a part in the formation of activity areas on sites in New England by examining gender-specific roles that seventeenth-century Anglo society dictated of men and women. Gibb and King point out, that while men and women do not always fulfill their socially defined roles that "nonetheless, the majority of women and men engaged in activities prescribed by tradition" (Gibb and King 1991:109). They explain the necessity of searching for gendered activity areas, saying that doing so provides a better understanding of "how English gender relations developed on the frontier and how those relations influenced the development of the colonial economy and the character of [English] European colonialism" (Gibb and King 1991:129). A similar search for deeper meanings in activity areas outside the Janis-Ziegler home will answer similar questions of how these relations between men and women as well as between social classes influenced the formation of social hierarchies within Ste. Genevieve. 


\section{Summary}

The Janis Occupation

Part of this study includes trying to better understand the enslaved individuals living and/or working within the outbuilding on the Janis property. Though there are similar studies (e.g., Samford 1999; Steen 1999; Stewart-Abernathy 2007; Armstrong et al. 2008) that investigate the living spaces of enslaved Africans and African Americans, very little work has so far been undertaken to understand slavery in the North American French interior. As Armstrong points out, there is nothing monolithic or unchanging in the study of slaves (1999:175) and Young (1999) shows that even within a similar region slave situations can differ greatly. In analyzing the French slave period, I hope to better understand the dynamic social conditions found on the Janis property during their occupation of the site.

The Ziegler Occupation

During the Ziegler occupation of the site, the family spent a portion of their financial resources in hiring servants. The ethnic background of the servants included other Germans, Irish, and Americans. It will be interesting to see whether or not the ethnic differences of these individuals, with all the diversity in their backgrounds and upbringing, will affect the material culture that was recovered through archaeological excavations. The introduction of servants into the Ziegler household during a time and place where slavery was an acceptable means of conspicuous consumption may also shed more light onto ethnic differences between French and German settlers. 
This study will attempt to examine an outbuilding within a predominantly French community. More importantly, it works to include the "other" groups who are often left out of the more popular narratives concerning the elite families. Through questions concerning the occupational sequence, the function of the site, who was working/living within/outside the structure, and whether or not the use of the structure changed over time, this study hopes to reveal a more diverse Mississippi River valley. 
CHAPTER II

HISTORICAL BACKGROUND

\author{
La Louisiane
}

The middle-Mississippi River valley has always been an important region for trade, agriculture, and culture contact. Walthall and Emerson (1991) give the French interaction within this region three periods: the Exploration period that would last roughly from 1634 to 1717 (1991:5-8), the Colonization period stretching from 1717 to 1765 (1991:8-10), and the Creole period from 1765 to 1803 (1991:10-11).

On June 14, 1671 a gathering of fourteen tribes, Jesuit missionaries, and French officials assembled at Sault Ste. Marie (in what is today Michigan), a place that "unites the territory stretching from Lake Superior to the mysterious region of Lake Winnipeg with the territory around Lake Michigan and the Mississippi valley, and connects both with the waters flowing into the St. Lawrence" (Alvord 1920:61). Alvord writes that it was at this place that, "a solemn ceremony, half religious, half civil..." was held and "the country and all adjacent regions were declared to be in the possession of King Louis XIV" (1920:62). "The ceremony marked the auspicious opening of a great era of discovery. The immediate incentive to explore arose from the Indians' accounts of a great western 
river which they called the "Great Water," or "Missipi," as it was first transcribed by Father Allouez" (Alvord 1920:62).

The Exploration period (1634-1717) had officially begun with the landing in and the exploration of what was then considered a part of Canada, when Frenchman Jean Nicollet landed in Green Bay. "Within," as Walthall and Emerson (1991) state, "the next half-century, expeditions, most notably those of Marquette and Jolliet (1673) and La Salle (1679), entered the Illinois Country and explored southward to the mouth of the Mississippi River" (1991:5).

Louis Jolliet, one of the first great European/Canadian explorers of the region below the Great Lakes, was initially chosen by Jean Talon, the Intendant (a regional Governor) of Quebec (Chapais 1914:21), and then later by the Comte de Frontenac, who became the new Governor in 1762 (Alvord 1920:63), to lead the first state sanctioned expedition to explore the Mississippi River in hopes of finding a northwest passage connecting the middle Mississippi River to the Pacific Ocean. “On May 17, 1673, with five men, they [Jolliet and Jesuit Priest, Father Jacque Marquette] embarked in two canoes for the long voyage into the unknown" (Alvord 1920:63).

With the opening of the Jolliet-Marquette expedition, the French Illinois country became a place of exploration. Little actual settlement took place in the region during the earlier years. "Before the eighteenth century it is unlikely that any Frenchmen (and very probably no French woman) considered the area home. It was simply a place of business, whether commercial or spiritual" (Mazrim 2011:7). While colonists did not settle (mostly) until after this period within the region, European trade goods quickly 
made their way into the hands of the indigenous peoples, allowing the French, in at least this portion of the New World, to gain allies and trade partners within the region. Before widespread settlements grew within the territory, the French seeded the area with Jesuit missionaries, to convert local Natives to Catholicism and to trade and garner further alliances with local indigenous groups. In the later portion of this period, the French had mostly settled around their more populated and more easily reached centers in the Gulf Coast. Those areas in French owned lands north of the Gulf of Mexico that saw French-indigenous interaction were mostly those accessible via waterways and the populations therein remained few in number until later periods (Scott 2010:1).

The settlements that did emerge during this time (such as the villages of Cahokia and Kaskaskia, both in modern-day Illinois) "looked primarily like Native American ones, occupied by missions, a few priests, and a few French traders" (Mazrim 2011:9). Though little total commitment, it could be argued, was being made by large groups of French settlers in the region, those who did live within the Illinois Country tended to marry into local communities and populations, creating many different versions of Creolized "Frenchness" within the region, while also making it more comfortable for larger concentrations of French settlers to migrate into the area. "Although we may view" writes Gitlin (2010:10), "cross-cultural partners and métis men and women as inhabitants of a literal middle ground, French and Indian places remained distinct. But they were connected by a variety of bridges - primarily economic and linguistic, but also religious and social." These bridges, then, to borrow Gitlin's term, more so than for both the British and the Americans in the east, made it possible for the French to live and 
work side-by-side with Native peoples in places like St. Louis, Ste. Genevieve, Kaskaskia, Cahokia, and Peoria.

The second period of French interaction within Louisiane was the Colonization period (1717-1765) which lasted only a few generations. Alvord writes that, "France stood on the verge of bankruptcy; the government was making use of the worst financial expedients; commerce and industry had lost all activity; agriculture was at a standstill; economic stagnation was everywhere" and "Law offered an escape" (1920:150). To counteract the economic woes of France, King Louis XV's granted a charter, allowing John Law-the "central figure" in the French government's "get-richquick scheme"(Alvord 1920:149)_and his Compagnie des Indes "economic monopoly over the colony of Louisiane" (Walthall and Emerson 1991:8). The charter, granted in August 1717, would be valid for twenty-five years and would give Law's

"company a complete trade monopoly of Louisiana even including the buying of beaver; free disposal overall all forts, ports, depots, and the garrisons of the province; ownership of all mines opened up by the company; free importation of French goods into Louisiana and a reduction of the duty of goods imported into France; freedom to issue orders regulating the interior conditions of Louisiana as regards commerce and the relations with the Indians; and the right of appointment of all officials, including judges. The charter imposed upon the company the obligation of recognizing as law the coutume de Paris and of importing into the territory 6,000 white persons and 3,000 Negros" (Alvord 1920:150-151).

The charter's aim, and its importance to this period of French settlement within the Illinois Country, rested on its ability to boost economic productivity and exchange between the motherland-France-and the colony, create increased immigration to lands owned by the French in France's little inhabited (by French citizens at least) 
territory, as well as stem the flow of English activity in the west. This caused increased activity within the Mississippi valley. As people settled and French agriculture emerged, trade shipments began in annual convoys to travel the Mississippi River reaching out to touch places and people near and far away. "In addition to the fur trade related profit and mineral discoveries it hoped to gain, the company also intended to establish Illinois as a granary for the lower colony, thus reducing food-related expenses" (Mazrim 2011:9).

The charter, though it would only last until 1731, would aid in producing some of the methods needed to reduce the national debt, but to capitalize on all of the charter's advantages would also require increased settlement within the French colonies on the continent of North America. To make immigration seem more pleasant, Alvord writes that, "newspapers and pamphlets with lurid accounts of Louisiana's wealth were widely distributed: mountains there teemed with the precious metals, savages were eager to trade gold and silver for European merchandise; Natchez squaws were manufacturing silk. Former Governor Cadillac loudly proclaimed such descriptions lies, and was thrown into the Bastille by the government" (1920:151).

Though wildly creative, the grandiose accounts of France's new world holdings were not as wholeheartedly successful as they could have wanted. Many people were "drafted" into the colonies. Many were bribed with the guarantee of large plots of land for farming, and some new "immigrants" were even compelled to leave, in a similar manner to the colonization of Australia by the British - prisons were emptied, "vagabonds from the streets" were seized, and those without families were strongly encouraged to make the voyage (Alvord 1920:152). By 1720, citizens of France had speculated wildly on the 
results of Law's charter and its failure in the same year shook the French economic structure. Though he fled to Belgium (Mazrim 2011:9), Law and his charter had ultimately brought France 1,600,000 livres and he had "taught the nation how to use credit, he had stimulated trade, and had reduced the national debt" (Alvord 1920:151).

As mentioned above, although agricultural pursuits, and to an extent mining, were some of the biggest economic endeavors found within the Illinois Country, there were other trades that made an impact within the region. The most influential economic venture within the bounds of the upper Louisiane grew on the bodies of small fur bearing animals. "During this period French officials used the fur trade as a diplomatic tool to maintain Indian alliances and to cement new ones" (Walthall and Emerson 1991:10). However, it was not foolproof and by the later part of this period, the intertribal competition for trade goods led to increased violence (inter-tribal as well as between the indigenous groups and the French) within the region. On top of the hostilities stirring among local groups in the Mississippi valley at the end of the second period, the French in the north-east were also at war with the British. The Seven-Year's War, also known as the French and Indian War, marked the end of French political control in the region. In 1765, two years after the end of the French and Indian War, the British marched their way into the region and formally took over leadership.

The last of periods to be almost wholly French can be termed the Creole Period (1765-1803) and actually saw the territory slip into Spanish hands. The era saw, at its beginning, the end of the French and Indian War, resulting in the division of once French lands into British and Spanish territory, with the English on the east side of the 
Mississippi and the Spanish to the west. When the French lands on the eastern shore of the Mississippi River came into British hands, many French settlers living in towns like Kaskaskia and Cahokia immigrated quickly across the river into similarly Catholic Spanish territory (Alvord 1920:346; Keene 2002:56; Mazrim 2011:11; Schroeder 2002:83). This caused much depopulation in the French villages to the east of the Mississippi River and a period of growth in ones to the west such as Ste. Genevieve (established around 1750) and St. Louis (established in 1764).

The similarities between the French and Spanish systems and cultures made the transition from French territory to Spanish territory relatively easy. The "basic cultures, when viewed from the process of settling land in eighteenth-century America, were similar in types of agriculture, the form of settlements, community structure and land law. Spanish and French agricultural and settlement systems had more in common with each other than either had with English, American, or any of the indigenous Indian systems" (Schroeder 2002:83). There were differences existing in slave systems, but they were few and far between and less of an issue or a concern for those living within the territory.

The French under the Spanish regime saw no sudden shifts in control. It may have been a Spanish territory in name and on maps, but the region was still very much culturally French, and would happily remain so during the entire Spanish period. "Realizing that they did not have the manpower or expertise in local Indian affairs to do otherwise, the Spanish were content to let French Creoles run their own show in their own language" (Gitlin 2010:49). The spoken language remained primarily French, and 
the French retained the on-the-ground control of the region with the Spanish blessing. "The superficial overlay of Spanish law upon French custom in Upper Louisiana, in regards to settlement, was exemplified by the Spanish choice of local officers. Men of basic French culture administered the local districts" (Schroeder 2002:83).

"For the Spanish, settlement of distant Upper Louisiana was always of secondary concern to their presence at New Orleans and Lower Louisiana" (Schroder 2002:89), but the Spanish began to actively seek out immigrants, as the French had, to halt British and American advances west into Spanish territory. Spanish imperial administrators, who governed the colony from 1762 until 1800, when it was returned to France, became increasingly fearful of peoples who arrived in Louisiana from the United States, France, and St. Domingue [Haiti] with an open disrespect for royalists" (Vernet 2008:495). "Hopes to attract Spanish Catholics were never much more than that. Spain tried to induce the settlement of the Acadians, and then of Irish, German, and French Catholics, but few of the Europeans came"(Schroeder 2002:88). The Spanish next tried to entice Americans from a Catholic background into the territory, promising land. Kaskaskians and people from other French villages continued to trickle into Spanish lands, "as a result of the imposition of new U.S. laws, especially the prohibition of slavery in the newly organized Northwest Territory" (Schroeder 2002:91). "Among the new arrivals," Schroeder writes, "were some of the wealthiest Kaskaskia families, such as the Janis, Ste. Gemme Beauvais, and Caillot dit Lachance families" (2002:91).

On December 1, 1788, policy changed and the Spanish began allowing Protestant Americans into the territory, as long as they took an oath swearing that they would a) 
raise their children to be Catholics b) refrain from public worship and preaching, and c) swear allegiance to the Spanish king. However, nothing much came of the new allowances (no sudden hikes in the American segments of the population)-the Americans in the east were still too consumed with settling and exploring Kentucky and Tennessee and recovering from the American Revolution. The Spanish would continue to struggle to find people to fill up the empty spaces within their territories. They tried offering more land to those with higher numbers of slaves; they actively sought out French, German, Dutch, and Flemish Catholics, as well as those of the ancien régime who were fleeing revolutionary France (Schroeder 2002:94-95).

The Treaty of San Lorenzo del Escorial, or Pinckney's Treaty (October 27, 1795), would change the name of the game between the Americans and Spanish territory. Major allowances were: the crossing of the Mississippi River duty-free by Americans and it gave Americans "the right of deposit (to unload and load) at Spanish New Orleans" (Schroeder 2002:96). From this point on, "Spain forever abandoned thought of eventual incorporation of Louisiana as an integral part of its empire and began entertaining notions of using the non-Hispanic province as a pawn in international diplomacy" (Schroeder 2002:96). Schroeder (2002:112) sums up the total impact of the Spanish on the Illinois Country: "thus, the Spanish administration in Upper Louisiana ended without leaving much of an imprint on its settlement...Spanish policy was successful by impeding American settlement until 1795, but after then Americans forced Spain to let them enter with their own settlement practices" (Schroeder 2002:112). 


\section{American Transition and Growth}

In 1803 the United States government under President Thomas Jefferson bought the land west of the Mississippi River. Theoretically, the lands belonging to the inhabitants of the land were to stay in their hands, but according to Schroeder (2002:114-115):

The French had a paternalistic institutional system whereby a commandant or cleric oversaw the individual's welfare. The village settlement system, made cohesive through kinship ties and close spatial contact, promoted group solidarity and looked to tradition as the way to do things. The commandant arbitrated differences. The public and legal institutions of the Americans, in which responsibility lay with the individual and his initiative, were difficult to understand for these French. Consequently, many failed to present themselves before American authority and apply for titles to their lands, even though they held concessions to them....in addition, a certain complement of the French had never bothered to get a concession, because their commandants had told them that the "ax and the plow' are the best proofs of landownership."

From the point of American ownership of the west side of the Mississippi River, immigrants flooded over, spread out, settled, and created communities, but because of the bureaucratic mess, in part due to the difference in land acquisition prior to the American period, few could legally gain title to the land (Schroeder 2002:117).

Despite being under American rule, French communities along the Mississippi River retained much of their traditions and ways of life, and indeed, the power of many of the French merchants living in St. Louis and Ste. Genevieve expanded during the early stages of the American period. Gitlin (2010:56) writes that the French were often "pictured as infantilized and backward peasants and fur traders, quite literally the children of the empire." "The French," Gitlin (2010:56) continues, "have appeared in many a historical novel as passive spectators to the noble exploits of Anglo-American liberators such as George Rogers Clark and Andrew Jackson." Gitlin (2010) emphasizes, 
however, that "American politicians quickly learned that it was not correct. Any perceived American attempt to deprive the French of their political voice or their property drew an immediate response" (Gitlin 2010:56). Many American businessmen and traders complained loudly and often of French trading monopolies with local tribes. Despite an intense contempt for the other, the French learned to live with American rule, as the Americans learned to live with, as well as often marry into, the French elite in the river cities of the Mississippi.

Slavery and African Slaves within the Illinois Country

The study of slavery within a society may act as a means of understanding the social order and culture of the time-for all groups - the elite and the poor, the owners and the owned, the marginal groups and the principal players. French slavery in the Mississippi River valley was unlike the British and American models that dominate historical and archaeological studies of U.S. slavery. It was not better or worse than the British or American models-slavery was still slavery, people were still owned as property, and families were still broken up-but it arose and became popular due to important occurrences taking place within the region and abroad at the time.

Regardless, slaves, as individuals as well as workers, played a very important role in the formation of the region.

"French colonies in the New World were chronically short of labor" (Ekberg 1996:196). A part of the history of the Illinois Country often left out are the marginalized groups within French colonial society-Native American and African slaves. Slavery (in this case Indian slavery) in French colonial contexts could be seen on the continent of 
North America as early as the 1670 s, but Indian slavery was impractical on a large scale because of high rates of population decline due to disease and the slaves' ability to easily return to his/her original home after escape (Denevan 1992). It was trade with French islands in the Caribbean - the so-called "Sugar Islands"-Martinique, Guadeloupe, and Saint-Dominque-that spurred the institution of slavery within the Illinois Country (Ekberg 1996:196). "Black Africans," Ekberg writes, "better withstood European diseases and had become accustomed to the institution of slavery within Africa" (1996:196).

"The heat and insects of the Gulf Coast were punishing for men accustomed to the temperate climate of France, and orphans, convicts and vagabonds sent as laborers to Louisiana died in droves" (Ekberg 1996:197). The French desired the African slaves working in plantations on the sugar islands because they offered a means to supplementing work that they were not at all times fully capable of doing themselves, in climates that they were unused to (at least initially)(Ekberg 1996:197). Slaves could be found in lower Louisiana, even if it was in small numbers (at first), as early as 1712.

French-Canadian missionaries and settlers had seen Indian slaves prior to coming into the middle-Mississippi River valley, but they had no direct access to African slaves. The slaves who would eventually find themselves imported into the region then necessarily came from the south-from the lower Mississippi River valley (Ekberg 1996:197). “By 1719, shortly after New Orleans was founded, several shiploads of blacks arrived in Louisiana" (Ekberg 1996:197) and by default the Illinois Country (though most likely in small numbers earlier on). Ekberg (1996:197) writes that it seems "likely that 
Jesuit missionaries were the first owners of black slaves in the Illinois Country" and that the "Jesuits with their substantial financial resources and powerful political connections were in the best position to purchase slaves and have them shipped up the Mississippi."

Though slavery is justifiably looked down upon in modern society-French slavery within the Illinois country was a different kettle of fish compared to that of the sugar islands or even that of the lower Mississippi River valley where large plantations were common and large labor forces necessary. Ekberg characterizes this, writing: "life for slaves was certainly less harsh in the Illinois Country than on the Caribbean Islands; if blacks were not reproducing rapidly in Illinois during the 1730 s they at least were not dying like flies as they did on the notorious sugar plantations in the West Indies" (Ekberg 1996:199).

Slavery within the French system was controlled by a system of regulations designed to increase production and morale (in the philosophy that a happy slave was a productive slave) called Code Noir (or Black Code). Under the French rule (it existed in similar form under the Spanish crown-which will be discussed later) slaves were legally defined under the Black Code as: "chattels that could be bought and sold like other personal property. Yet the code also clearly recognized slaves as human beings" (Ekberg 1996:204). Ekberg writes that under the French system, the "Black Code is a dispassionate and tightly reasoned document-reasoned to serve not the slaves, nor even their masters, but rather the interests of the absolute French state" (1996:204). Under the French Black Code, the following points are made (Ekberg 1996:204-295): "slaves had to be properly clothed, and fed; slave children could not be sold away from their parents until they had arrived at puberty; masters could whip and bind their slaves, 
but the slaves could not be imprisoned, mutilated, or put to death without due process of law; slaves could not be worked before sunrise or after sunset; old and infirm slaves had to be cared for; slave women were not to be sexually exploited; slaves were to be baptized and instructed in the Christian (i.e. Roman Catholic) faith; slaves could not carry firearms, or even "large sticks"; slaves were to be encouraged to marry with their masters' consent but could not be compelled to marry against their will; interracial marriage and cohabitation were forbidden; masters could not manumit slaves without government permission. Finally, the code provided slaves with the right to take their masters to court at no cost if they felt their masters were abusing them in violation of other articles."

The French system, then within the Illinois Country, though still an institution of forced labor perpetuated upon a group of individuals solely because of skin color, was significantly better, and perhaps more relaxed, than found to the east of the Mississippi River. The issue of intermarriage was one of more concern elsewhere than found among the populations inhabiting the west bank of the Mississippi River. The realities were that manumission and marriage could potentially mean a lessening of labor within the region. Less labor (slave or otherwise) meant less money in the pocket of the French government.

Though the French Black Code set up a cookie-cutter approach to slavery, local, on-the-ground realities often differed from the expectations of the state. Ekberg (1996:209) gives a potent example of how those on the community level at times resisted state proclamations in part or in whole by describing a series of complaints and correspondence which took place within Ste. Genevieve in 1786 between town commandant Antonio de Oro and the lieutenant governor in St. Louis and the governor general in New Orleans about the Vallé brothers-François II and Jean-Baptiste- who "were allowing their slaves to carry firearms" "in clear violation of Article XII of the Louisiana Black Code." Their response was, "that their slaves were obliged to carry 
firearms in order to defend themselves against hostile Indians and wild beasts, including "tigres" (apparently cougars)" (quoted in Ekberg 1996:209). The Vallé brothers won their case and "henceforth the Valle slaves carried firearms in open violation of the Black Code. The Vallé brothers had political clout, and they also apparently had great faith in the loyalty of their black slaves" (Ekberg 1996:209).

When the Spanish took possession of the region west of the Mississippi River, the regulations concerning black slaves within the territory became even laxer. Under the French period miscegenation was frowned upon, not so much for the racial reasons that commonly caused racial violence and/or tension within later American contexts, but because of the effects it had on business-people in relationships with slaves often wanted to free slaves or free the mixed children, resulting in less labor to send resources back to France. "The French code proscribed miscegenation, which had never much bothered the Spaniards, and also discouraged slaves from purchasing their own freedom, which Spanish laws specifically condoned" (Ekberg 1996:207). Different cultural views of miscegenation almost certainly caused tension. And these relationships apparently occurred fairly regularly (Ekberg 1996:225-226). One example involved Antoine Janis, one of the sons of Nicolas Janis who was raised on the site being analyzed here. In 1796, Janis, a member of the French elite within the community, ruffled feathers because he had an affair with a mulatto slave owned by his brother-inlaw. It was not the affair itself that sent the community into a tizzy, but Janis' response to her owner sending the slave thirty leagues (or about 75 miles) upriver (this was done so that he could get over her). Antoine Janis followed Marie-Louise (the mulatto slave 
and his "concubine") and the community was aghast when he sent friends with large amounts of money to buy her freedom (see Ekberg 1996:225-228 for a more complete version of the story).

The natural environment and local occupations that sprang up in the French Illinois Country also had an impact on the social dynamics between slaves and their masters. Unlike situations in the lower Mississippi River valley where warm weather persisted year round and large plantations were more common, work was much more seasonal in nature in the Illinois country. Crops needed to be planted in the spring and harvested in the fall. Farm work between those seasons might have been relatively light and quickly accomplished. Because of the smaller number of slaves within most communities in the Illinois Country, the likelihood also exists (because most individuals within the Illinois Country owned very few slaves) that the French settlers within the region most likely worked side-by-side with slaves in the fields and mines during the busier parts of the year and had more to lose if slaves were mistreated or harmed (again slaves were expensive and valuable commodities). Henry Brackenridge, who lived in the area as a boy, wrote: "their agricultural labors commence in the month of April, when the inhabitants, with their slaves, are seen going and returning, each morning and evening,...with their ploughs, carts, horses, etc." (quoted in Ekberg 1996:210).

African slaves within the Illinois Country were most commonly quartered in structures separate from the main house. "One thing, however stands out: black slaves, including domestic servants, usually were quartered in freestanding slave quarters independent of the master's residence. The residences of which there are descriptions 
simply were not commodious enough to house live-in servants, free or slave. There is no record [at least in Ste. Genevieve] of a residence in which space was allocated for servants' quarters" (Ekberg 1996:212). The town lots, as will also be described later, were examples of urban farmsteads (Stewart-Abernathy 2007:56)-meaning there were structures or features on the property that paralleled similar structures and features usually found in rural or agricultural settings (i.e., barns, stables, orchards, etc.).

Though the French and even the Spanish system of slavery seemingly represented an easier or kinder way of life for slaves than the British system, it does not mean that the life of a French/Spanish slave within the Illinois Country was necessarily easy or without pain. The Black Code did allow for whippings and episodes of extreme violence did occur (e.g., Ekberg 1996:238). And the slaves were still slaves-forced to work for others without just compensation or a say in it. At least within the FrancoSpanish Code Noir system slaves had a set list of rights. It was not the best of situations, but it was certainly not the worst. The Janis outbuilding, it is hoped, will provide a glimpse of what was normal for well-to-do families/slave owners within French families living within the middle Mississippi River Valley. As part of the examination of questions concerning identity and function, this study will also investigate the conditions African slaves lived with within the confines of the outbuilding on the Janis-Ziegler property.

Ste. Genevieve

The French settled into the first Ste. Genevieve around 1750 (Ekberg 1985:25) in what was primarily an agriculturally based community. Though other trades existed within the town —including salt making, fur trading and lead mining — the most 
successful economic pursuit in the earlier years was that of farming. Keene (2003) illustrates the impact this agricultural activity had within the French colonial system at the time, writing, "In effect, the Illinois Country became the bread basket for the lower Mississippi River valley and the Caribbean. Those settlements, receiving food from Illinois, could concentrate on other pursuits such as defense and trade in Louisiana and sugar production in the West Indies" (Keene 2000:34).

Farmers were very much self-sufficient in the Illinois Country and soon the population began to increase as new settlers moved into the area and in reaction to the territorial ownership change that occurred after the end of the French and Indian War. The French living within the British lands poured across the Mississippi River, and as Keene put it, "if the French colonists of the Illinois Country could not be ruled by a French Catholic, Bourbon Monarch they would prefer a Spanish Catholic, Bourbon monarch to a Protestant British one" (Keene 2000:69). With population increase the village of Ste. Genevieve grew and the economic endeavors within the community grew more complex (Schroeder 2002).

The city's proximity to the Mississippi River (see Figure 1) was in many ways a benefit to the growing community, but in 1785 , the town found itself severely flooded in waters twelve to fifteen feet deep (Hawkins 2007:27) in what was "probably the record flood on the middle Mississippi River" (Cox 2009:3; Ekberg 1985:421). The townsfolk of what was later designated Vieux (old) Ste. Genevieve relocated to higher ground on a "colluvial deposit at an elevation approximately 6.5 meters ( 21.3 feet) above the ground surface of the original site" (Norris 1991:134). 
From the time that the Americans bought the region in what is today famously referred to as the Louisiana Purchase, the community of Ste. Genevieve became more "other" and less French. The Americans streamed into the region in search of better business opportunities and new lands to settle. Other groups, including a large influx of Germans in the mid-nineteenth century, also made up a large proportion of the city. Today the city still functions, but it sees less capital in agricultural production and more in tourist activity thanks to its claim to the largest concentration of French colonial homes in the United States.

The Janis-Ziegler House

The Janis-Ziegler house is located on St. Mary's road in Ste. Genevieve, Missouri, south of Gabouri Creek. It was built in 1790 by Nicolas Janis (father of Antoine mentioned earlier) of a vernacular timber frame construct called poteaux sur solle, otherwise known as post on sill construction (Edwards 2006:23) (see Figure 1). Dendrochronology marks the house as the oldest standing building in the state of Missouri (Evans 2001:57) and architectural historians have dubbed the home as a house in "transition" because of its mixing of "French and Anglo building methods" (Cox 2009:11). For the Janis family, this property included several outbuildings, a stable, barn, as well as a garden and orchard (Hawkins 2007). 


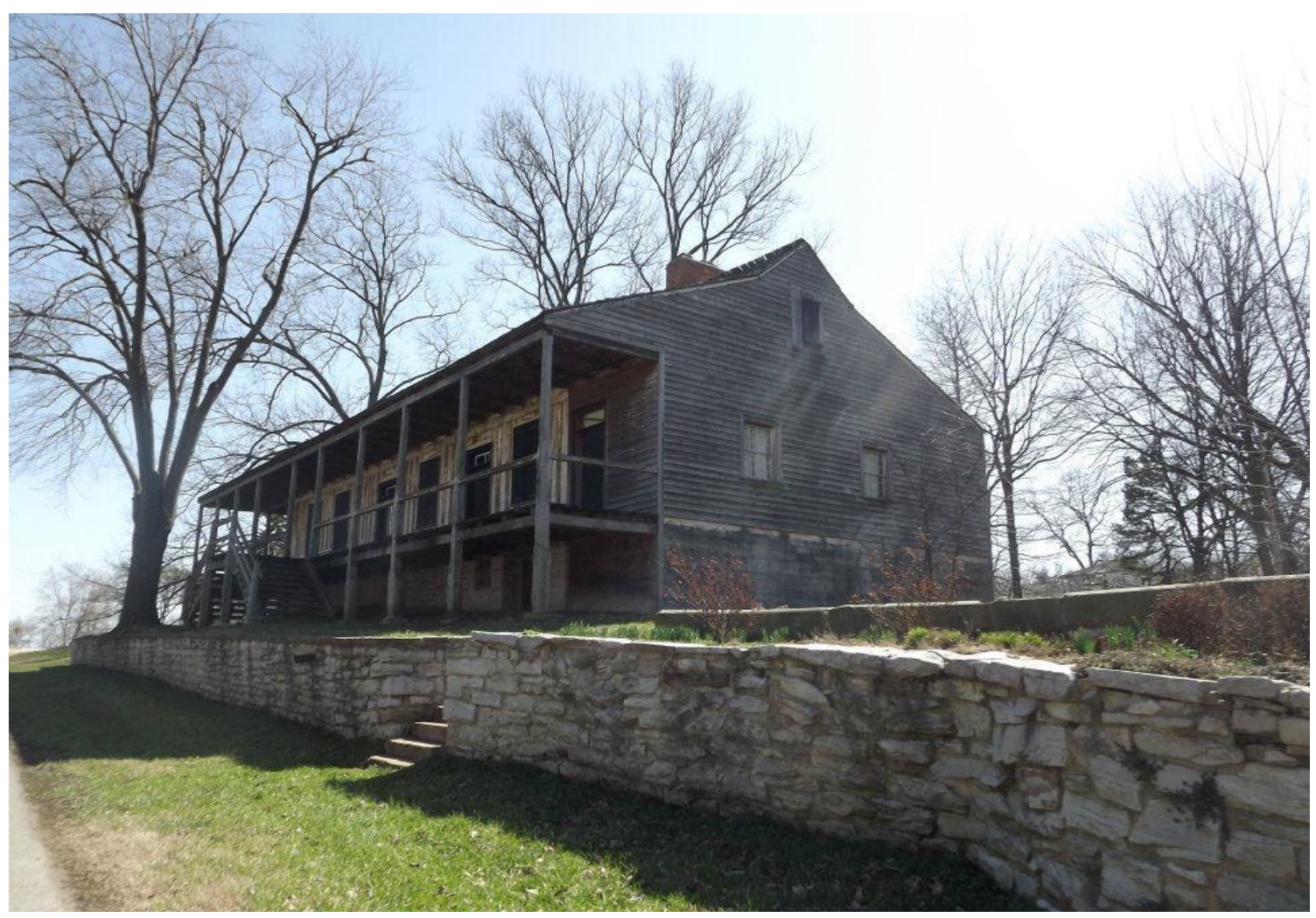

Figure 1. Janis-Ziegler House, Ste. Genevieve, Missouri.

The first owner, Nicolas Janis came first from Quebec, Canada to Kaskaskia, Illinois. In 1751 he married Marie-Louise Lasource (Hawkins 2007:31). From Kaskaskia he fully and officially moved to Ste. Genevieve between 1789 and 1790 (he had owned land prior to his move to the area within what was called le grand champ [or the Big Field] ([Ekberg1998:34]). Nicolas Janis was wealthy, owning nineteen slaves (Ekberg 1996:432) in 1789. Two years later, according to a census conducted by the Spanish government (Houck 1909:367), the Janis family had ten slaves living on their property. Regardless of numbers, the Janis family owned slaves while they occupied the site-and slaves were a visible and very public sign of wealth and status. He was also well connected to many prominent families in the area through the marriage of his children. 
François, Nicolas' son, raised his family in the house/tavern and continued to engage in farming as well; at his death, he owned seven slaves (Ste. Genevieve County Deeds 1833). Thus far, no documents have been found that mention where the slaves lived, but it is likely that they lived in a separate structure on the Janis town lot (Ekberg 1996:12-13). Therefore, the archaeological evidence from outbuildings such as the one analyzed here becomes a possible way to make visible the daily lives of enslaved men and women. François Janis died in 1832 without a will and because his children already owned their own homes and properties and they expressed no interest in owning their father's property, it was sold to the Ziegler family in 1833.

Mathias and Barbara Ziegler moved to Ste. Genevieve from Baden in the Kingdom of Bavaria in what is today Germany (Hawkins 2007:34; Ste. Genevieve County Archives 1827). When Mathias bought the Janis' home in 1833 he used the building as both a residence and a tobacco wholesale shop" (Cox 2009:12; Franzwa 1998:137). Mathias Ziegler died rather unexpectedly in 1835 and his wife, Barbara, inherited the house, property, business and Mathias's debts (some $\$ 3,600$ worth). Barbara and her sons continued the tobacco business for several decades after Mathias's death, but in 1851 Barbara Ziegler, because of her husband's debts, was forced to sell the house and property on the steps of the courthouse; one of her sons, Francis, purchased the house and property for $\$ 1,750$. Barbara Ziegler would continue to live in the house until her death in 1862.

Francis Ziegler discontinued the tobacco business and was listed as an Assistant Marshall in the United States census of 1850 (US Bureau of Census 1850). He was listed 
as a clerk ten years later, along with his wife and family in the 1860 census (US Bureau of Census 1860). Francis Ziegler was also most likely the one, around 1860, to update the house in a more Victorian style, taking the estimated worth of the house from $\$ 800$ in 1850 to $\$ 1,200$ in 1860 (Cox 2009:13). As noted earlier, neither generation of Zieglers who lived in the house owned slaves; they did employ servants of Irish, German, and American heritage. Thus far, no documentation has been found that notes where the servants lived, so the archaeological record of the outbuildingf5 could provide important evidence of their daily lives. Francis Ziegler died in 1900, leaving the home to his son and four daughters (Beckerman 1984:38). His son Joseph had, by this time, married and moved out of the home, but his daughters, Barbara, Blanche, Isabelle, and Corrine remained single and continued to live in the house. In 1938 the last two daughters, Barbara and Corrine, sold the home to their nieces who, in turn, sold the house to the Moranville family (Ste. Genevieve County Archives 1938).

The house was sold twice more and in 1976 was bought by Norbert and Frankye Donze (Franzwa 1996:138) who restored it and opened it to the public as a house museum until 1992 (Cox 2009:14; Evan 2001:58; Franzwa 1996:138). Like many of the other historic homes along the Mississippi River, the Janis-Ziegler home found itself sitting mostly (more than eight feet) underwater in the 1993 flood for two months (Cox 2009: 14; Hawkins 2007:37), leaving much damage. In 1996, Hilliard and Bonnie Goldman purchased and began the intensive renovations of the house that continue today. 


\section{Summary}

Much of the little of what the general public knows of the French interactions in the Mississippi River valley is closely associated with New Orleans and the lower Mississippi River valley. The diversity found in the lower region-French settlers, African slaves, mulattos, Native Americans, Métis, and immigrants from around the world-also emerges in the middle Mississippi River valley. The number of times in which the territory switched hands - from French to Spanish to American-and all the interactions therein as part of colonial and post-colonial efforts-have left a permanent and colorful stamp across the region's people, traditions, architecture, and the relationships that took place across the social landscape therein. These interactions also directly impacted the domestic sphere in communities like Ste. Genevieve, Missouri. They shaped what goods could be easily and cheaply obtained, and who used such items. They shaped what was acceptable behavior and interaction between peoples of different class, ethnicity, and gender. These connections also directly impacted the course of development within the region. Many of the French ways of doing things-for example the long lots in farming as well as the ability of women to own property-remained in practice within the community even after the French lost control of the area. It is important to know the chronology of the area, how and with whom various groups of people interacted because these things impact even the smallest aspects of life, including small outbuildings that remained unlabeled on maps and in deeds. 
CHAPTER III

\section{METHODOLOGY}

The first systematic archaeological investigation completed on the Janis-Ziegler property took place in 2006. It was conducted as a field school through Illinois State University under the direction of Dr. Elizabeth M. Scott and Dr. Donald P. Heldman and included six students and a volunteer (Hawkins 2007:42) over a period of six weeks. The units of excavation were organized in $5^{\prime} \times 5^{\prime}$ units and the property was "divided into a grid of $10^{\prime}$ squares on which the $5^{\prime} \times 5^{\prime}$ excavation units (quadrants) were placed" (Hawkins 2007:42). The units associated with the outbuilding (110R0 Qu. 1, 110R0 Qu. 3, and $110 \mathrm{~L} 10 \mathrm{Qu} .2$ ) were located on the southwestern portion of the property (Hawkins 2007:42) and were excavated in 2006-2009. The unit associated with the main structure (110R30 Qu. 2) was located on the western side of the building in the back yard, within sweeping distance of the porch and was excavated in 2006 (Hawkins 2007:42) (see

Figure 3). Excavation units were completed by hand using trowels and layers were removed in both arbitrary and natural levels as warranted.

In my analysis of the artifacts associated with the outbuilding at the Janis-Ziegler site, my first goal was to identify the occupational sequence revealed in the excavation units. To do this, I examined the artifacts associated with each level and then used them 
to aid in dating the corresponding levels. Using mostly ceramic and glass artifacts, I was able to align corresponding depths from three adjacent units (110R0 Qu. 1, 110R0 Qu. 3, and $110 \mathrm{~L} 10 \mathrm{Qu} .2$ ) to form a clear idea of which deposits could be tied to a Janis (1790 to 1833 ) or Ziegler (1833 to 1900) period of association. The Janis and Ziegler occupations will be listed in this portion as both levels and depth measurements because of the differences in excavation increments between unit $110 \mathrm{~L} 10$ and the other units in 110R0. The depths below datum that are represented for each of the undisturbed deposits are:

110R0 Qu. 1: Ziegler Occupation (1833-1900) - Levels 5 \& 6 [0.65' to 1.05'] Janis Occupation (1790-1833) - Levels $7 \& 8$ [1.05' to $\left.1.45^{\prime}\right]$

110R0 Qu. 3 Ziegler Occupation (1833-1900) - Levels 5 \& 6 [0.65' to 1.05'] Janis Occupation (1790-1833) - Levels 7, 8, 9, 10 [1.05' to 1.74']

110L10 Qu. 2 Ziegler Occupation (1833-1900) - Levels 5, 6, 7, 8 [0.65 to 1.05'] Janis Occupation (1790-1833) - Levels 9, 10, 11, 12, 13 [1.05' to 1.59']

After determining the outbuilding's occupational sequence the next most important step was to establish the function of the structure. I needed to first establish the minimum number of vessels (MNV) per occupation and I needed to form functional categories for activities associated with the artifacts recovered in/around the outbuilding. The MNV was identified by, as the name implies, figuring the minimum number of vessels represented by the sherds in each occupational sequence (Miller 1980). I used sherd decoration to determine which vessels could be distinguished individually. Those sherds not distinct enough to be conclusively placed within a unique vessel (usually the small plain fragments or the fragments associated with wares that 
seldom have as much decoration as the refined white earthenwares-creamwares, yellowwares, stoneware and coarse red earthenwares for the most part) were associated with the ceramics that appeared strikingly similar to each other in texture, color, thickness, glaze, and form. Through this system, it was determined that the Janis occupation at the outbuilding had a minimum number of 12 vessels while the Ziegler occupation had a minimum of 29 (see Appendix).

After establishing the minimum number of vessels associated with each occupation, I placed the vessels into four basic functional categories-food preparation, serving and consumption, food storage, and unidentified. After removing the unidentified pieces from the equation - they contributed little to the understanding of what activities might have been taking place around the structure-patterns for both occupations began to emerge, especially when the same processes were applied to the functional ceramic categories associated with the main house.

I placed the other artifacts in the assemblages into functional categories and soon had a much more diverse idea of the functional activities that were taking place in/around the outbuilding. I categorized the artifacts associated with both the outbuilding and the main house into functional categories by first looking at what activities were represented by each artifact present within the assemblages. The functional categories used for the analysis of artifacts include: construction and maintenance (nails, brick fragments, lime mortar/plaster, window glass, bousillage, staples, and slate), animal shoeing (small L-shaped nail), furnishings (tack, screw, curtain hook), health/sanitation (pharmaceutical bottle, chamber pot), fuel (clinker/cinder, coal, 
charcoal), food remains (bone, eggshell, shell), plant remains, domestic fowl production (gastroliths), hunting/weaponry (gun flint, lead shot), lead shot production (lead trailer), trade (catlinite), tool (knife, whetstone, wire), sewing (straight pin), clothing (shoe eyelet, hook and eye, button, snap), serving and consumption (bowls, saucers, cups, medium hollowware, medium-large bowl, platter, glass vessel, small bowl, straight sided bowl), preparation (large bowl), storage (ovoid crock/butter jar, barrel band, clear bottle, dark amber vessel glass, paneled bottle, and other (unidentified metal fragments, sheet metal, unidentified spherical worked stone)(see Appendix for a more detailed listing of artifacts within the functional categories).

The ceramics recovered at the outbuilding, as well as those recovered and discussed by Hawkins (2007) at the main house, were also used to determine differences in the class and/or economic status between those living in the outbuilding and the main structure. Under Miller's (1980) system, ceramics can be placed within four categories or price ranges. The first level (the lowest level on the scale) usually includes undecorated or plain ceramics. The second level includes "minimal decoration" created by “minimally skilled operatives" (Miller 1980:3), such as "shell-edged, sponge decorated, banded, mocha, and "common cable" (finger trailed slip). The second level "encompasses the cheapest ceramics available with decoration" (Miller 1980:4). The third level is "made up of painted wares with motifs such as flowers, leaves, stylized Chinese landscapes or geometric patterns; in this group "the painters needed to have enough skill to duplicate patterns so that sets of matched plates could be assembled" (Miller 1980:4). The fourth and final level includes the most expensive of decorated 
wares on Miller's list: the transfer prints. "In the 1790s, transfer printed vessels were three to five times more expensive than undecorated CC vessels [cream-colored vessels], but the price differential of printed and $\mathrm{CC}$ vessels decreased to between one and a half to two times the cost of CC by mid-19 $9^{\text {th }}$ century" (Miller 1980:4). I then used Miller's categories to gauge the economic position of each structure during each occupation.

After separating out the functional categories and the class based differences between the main structure and the outbuilding, I searched for gendered differences between the assemblages. I placed within each of the gendered categories (men, women, and undetermined) the functional categories most likely to have been associated with them using Gibb and King (1991:113). The functional categories associated with gender include (to see a more detailed version of Table 3.1 see Appendix): 


\begin{tabular}{|l|r|}
\hline \multicolumn{2}{|l|}{ Data Table 3.1 List of Functional Categories and their } \\
Gendered Associations. \\
\hline Functional Activity & Gendered Association \\
\hline Animal Shoeing & Men \\
Construction and Maintenance & Undetermined \\
Domestic Fowl Production & Women \\
Food Remains & Undetermined \\
Health/Sanitation & Men \\
Hunting/weaponry & Women \\
Interior Design and Decoration & Women \\
Food Serving and Consumption & Women \\
Food Storage & Women \\
Food Preparation & Men \\
Tool & Undetermined \\
Clothing & Men \\
Lead Shot Production & Men \\
Sewing & Undetermined \\
Trade &
\end{tabular}

Another aspect of identity examined in this study was race/ethnicity. I attempted to find artifacts that may have had characteristics or associations generally connected to the ethnic groups that were present on the property in both occupations, based on the findings of previous archaeologists and discussed earlier (Zug 1986; Groover 2003;

Baumann 2008, Brighton 2011). I also attempted to find ethnic affiliations through other means, including the examination of the on-the-ground realities of slavery on the property and through the architectural remains left after the demolition of the outbuilding.

I then turned to the question of change over time. Was there noticeable change between the Janis and Ziegler occupations at the site? Were there sudden shifts within 
the use of the outbuilding? I used several data sets to examine the question of change over time: the percentages of artifacts found, change in function over time within the outbuilding, the economic position of those living in the main house and those living in the outbuilding, and the gender of those associated with the space in question. I also used a chi square analysis to determine if there was significant difference between one occupation and the other and if it was solely due to chance.

Summary

I approached the analysis of the artifacts from the outbuilding in the same order chronology by examining the datable artifacts present in the assemblage. Next was the investigation of the functional activities - I looked at each artifact and placed it within a functional activity in search of the purpose of the outbuilding. I then looked at the social class associated with each ceramic type in search of who was working/living within the outbuilding and main structure. I then compared the assemblages of the outbuilding and the main house in order to see if there was noticeable differences and compared the two occupations to see if there were changes taking place over time within the social dynamics of those living and working on the property. Lastly, I compared the data connected to the outbuilding to that of the main house to better grasp an understanding of what differences in living/working conditions might appear and what that might tell about the property's social dynamics over time. 
CHAPTER IV

ANALYSIS

Stewart-Abernathy (2004:56) defines an "Urban Farmstead" as a house lot "that contained the house itself and necessary spaces and structures to support the household in a time when city services were minimal." "Urban households," StewartAbernathy continues, “incorporated into their residential spaces certain 'alien' elements such as chicken houses and gardens that stand today associated mostly with rural living" (Stewart-Abernathy 2004:56). In other words, the "urban farmstead," in this case the property belonging first to the Janis family, and later to the Ziegler family, was semi-selfsufficient, able to provide for some of the needs of the family and individuals living at the home. For the Janis family, this included several outbuildings, a stable, barn, as well as a garden and orchard (Hawkins 2007). The continued presence of gastroliths or "gizzard stones" from fowl shows the Zieglers probably continued using such structures as chicken/geese coops after buying the property. A large barn (see Figure 2) can be seen to the south of the house inside the fenced lot in an 1880 photograph (Hawkins 2007:59), suggesting a continuation of semi-self-sufficiency by the Zieglers. However, the nature of the historical documentation that exists describing the Janis-Ziegler 
property, and its lack of detail, makes it necessary to depend on archaeological investigation to help narrow down the possibilities for interpreting the outbuilding.

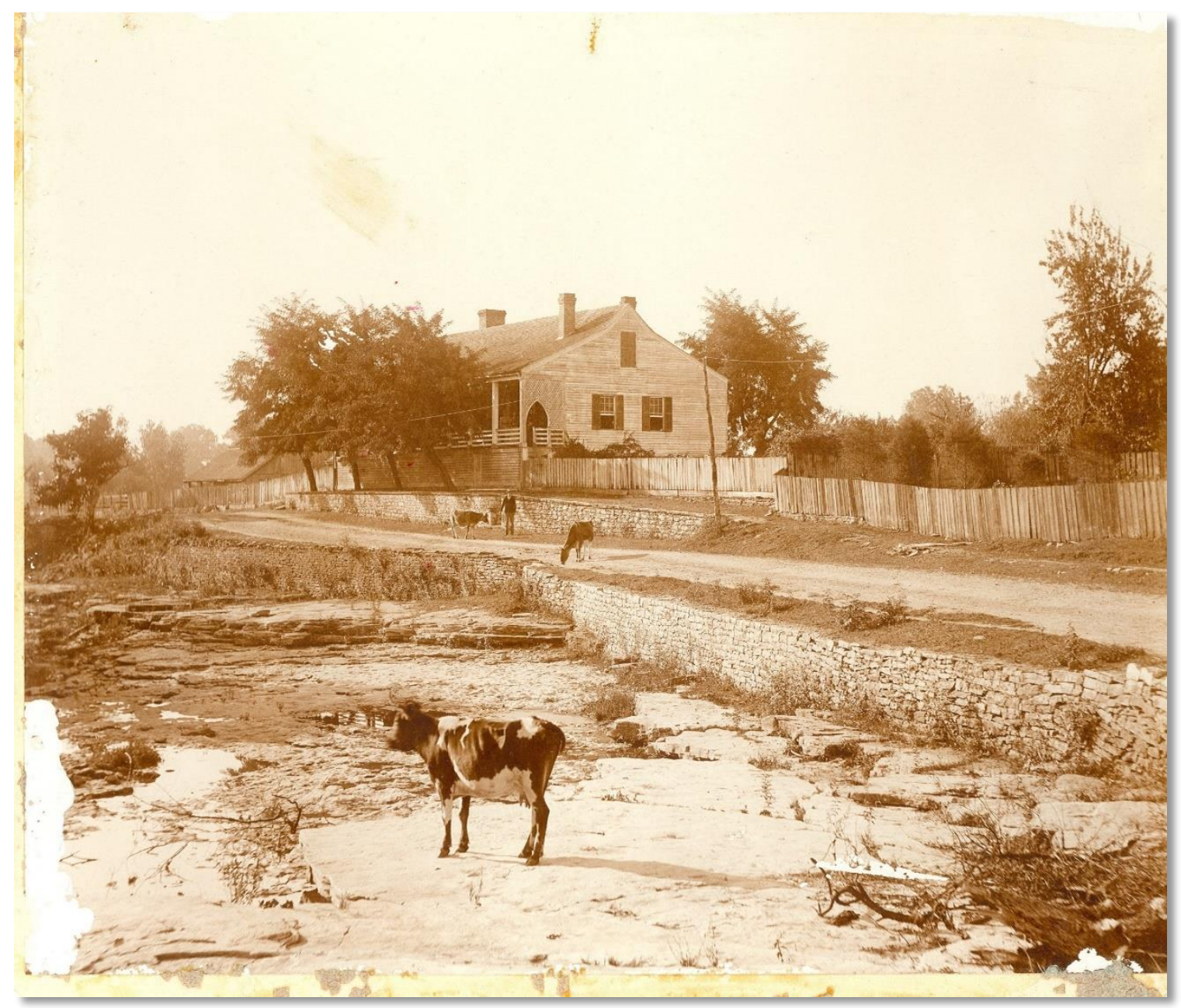

Figure 2. Photograph of the Janis-Ziegler Property c. 1880s Illustrating the Concept of an Urban Farmstead. Photo courtesy of the Missouri Historical Society, St. Louis, Missouri.

The Outbuilding Assemblages

Since no record exists that connects this outbuilding with a particular function it became necessary to narrow down our possibilities based on the material culture 
recovered from the site. The material culture located through excavation includes several material types, which can be seen in Table 4.1:

\begin{tabular}{|l|rr|rr|}
\hline \multicolumn{6}{|l|}{ Data Table 4.1 Artifact Quantities and Percentages from the Outbuilding by } \\
Occupation. \\
\hline \multirow{2}{*}{ Artifact Type } & \multicolumn{2}{|c|}{ Janis } & \multicolumn{2}{|c|}{ Ziegler } \\
\cline { 2 - 5 } & $\#$ & $2.1 \%$ & 73 & $6.8 \%$ \\
\hline Ceramic & 18 & $0.6 \%$ & 10 & $0.9 \%$ \\
Glass & 5 & $10.0 \%$ & 113 & $10.5 \%$ \\
Metal & 86 & $41.5 \%$ & 370 & $34.2 \%$ \\
Architecture & 357 & $9.2 \%$ & 35 & $3.2 \%$ \\
Plant Remains & 79 & $35.8 \%$ & 465 & $43.0 \%$ \\
Animal Remains & 308 & $0.2 \%$ & 5 & $0.5 \%$ \\
Gun parts & 2 & $0.1 \%$ & 0 & $0.0 \%$ \\
Whetstone & 1 & $0.6 \%$ & 10 & $0.9 \%$ \\
Gastrolith & 5 & $100.0 \%$ & 1082 & $100.0 \%$ \\
\hline Total & 861 & &
\end{tabular}

As seen from the chart above, the total assemblage is made up of a variety of objects, from architecturally oriented remains, which can be attributed to the construction, maintenance, and demolition of the building, to ceramics and food remains which presumably represent more of the day-to-day presence of those working or living within the building.

One of the highest proportions within the recovered materials are animal remains: bone, eggshell, and shell. The presence of these animal remains-at least some of which were related to food remains - as well as the ceramics within both the Janis and Ziegler contexts indicates a more domestic setting than might be expected by a barn or stable. While at least some of the animal remains themselves could be analyzed 
as things people in the past ate, they might also provide some insight into what types of food related activities might have taken place in/around the structure's confines. For example, the high occurrence of eggshell (see Appendix) within each occupation most likely indicates a high occurrence of food preparation taking place around the outbuilding. The presence of plant remains also made up a large proportion of the materials recovered from the outbuilding, possibly indicating more food remains.

While animal and plant remains make up some of the largest percentages of both the Janis and Ziegler occupations, the architectural remains also represent a large proportion of the artifacts found within the assemblage (see Table 4.2).

\begin{tabular}{|l|rr|rr|}
\hline \multicolumn{3}{|l|}{ Data Table 4.2 Architectural Remains from the } \\
Outbuilding by Occupation. \\
\hline \multirow{3}{*}{ Artifacts } & \multicolumn{2}{|c|}{ Janis } & \multicolumn{2}{c|}{ Ziegler } \\
\cline { 2 - 5 } Brick & $\#$ & $\% *$ & $\#$ & $* \%$ \\
Lime Mortar/Plaster & 106 & $29.7 \%$ & 143 & $38.5 \%$ \\
Window Glass & 4 & $65.0 \%$ & 125 & $33.7 \%$ \\
Cut Nail & 10 & $2.8 \%$ & 84 & $22.6 \%$ \\
Bousillage & 5 & $1.4 \%$ & 1 & $0.3 \%$ \\
Slate & 0 & $0.0 \%$ & 3 & $0.8 \%$ \\
Staple & 0 & $0.0 \%$ & 1 & $0.3 \%$ \\
Wire Nail (possible) & 0 & $0.0 \%$ & 4 & $1.1 \%$ \\
\hline Total: & 357 & $100.0 \%$ & 371 & $100.0 \%$ \\
\hline
\end{tabular}

*Percentage of each occupation's total architectural material

The architectural remains found at the outbuilding during both the Janis period and the Ziegler period have the potential to explain much about the intentions of the owners who built the structure. First the presence of brick fragments-all smaller in 
size - in both occupations is a probable indication, as seen in the still standing main house, of the presence of a chimney. Window glass indicates the need for light for activities taking place within the building coupled with the need to have the space within the structure protected from outside forces (weather, small wildlife, etc.).

Also within the architectural remains recovered, the Ziegler period shows an increased use of cut nails in the outbuilding. Though not an overwhelming amount of nails, the 84 nails ( $23 \%$ of the architectural artifacts found within this occupation) found from the Ziegler period far outnumber the 10 nails (or $3 \%$ of the total architectural artifacts from this period) recovered from the Janis period. This difference is enough to suggest that construction or maintenance on the outbuilding increased during the Ziegler occupation (Edwards 2006).

The few nails present before the Janis occupation may be explained in the construction of the overall building. Feature 7 within 110R0 Qu. 1 and 110L10 Qu. 2 shows closely spaced post molds that signify a poteaux-en-terre (post-in-ground) style of construction (see Figure 3), thought of most commonly as a vertical log cabin (White 2012:41). This particular style of architecture, unlike the poteaux-sur-solle (post-on-sill) construction of the main house, tended to be much more organic and easily destroyed. The in-ground wooden supports, because of the region's hot humid summers and cold humid winters (as well as problems with periodic flooding) would have required more upkeep and maintenance to ensure that the wood did not rot over time, especially when compared to structures, like the main house, that were built upon sills (Edwards 2006). Despite long term costs that might have added up over an extended period of 
time, the construction of the outbuilding in this fashion would have been more immediately cost effective-less gathering and/or quarrying rock from nearby sources to build the sills that are seen in poteaux-sur-solle architecturally styled buildings.

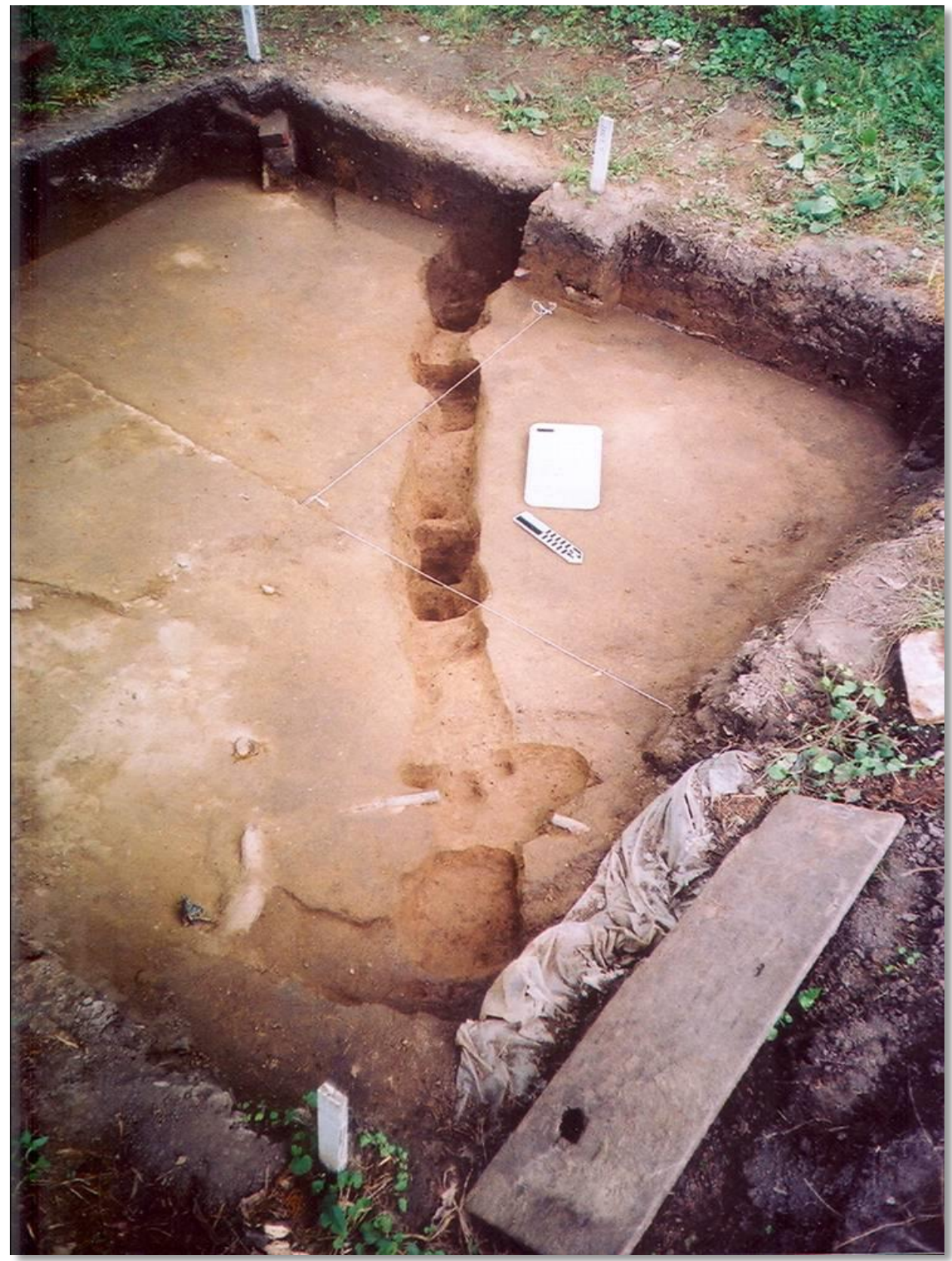

Figure 3. Image of Feature 7 (Post Molds from the Outbuilding). Photograph taken by Richard Young. 
The increase in cut nails within the Ziegler occupation may show change in the 1living/working conditions of the building itself. Though impossible to prove conclusively, the relative small number of nails in the Ziegler occupation, despite the increase in the percentage shown, most likely rules out any large construction or remodeling projects after the Zieglers took over the property. It seems most likely that some small work was done to the building, such as the installation of a floor or clapboards on one or more sides of the exterior.

With the presence of a fireplace, glass windows and possibly a wooden floor or weather-proof clapboards, the architectural remains indicate the space was used by people who spent much of their daily time within the structure. The Janis family records indicate that slaves came with them from Kaskaskia; they probably lived on the owner's property (Ekberg 1996:212-213). The records that exist for the Zieglers also show the presence of outside help in the form of servants living and working on the property alongside their employers.

The main houses of within the town of Ste. Genevieve were for the main families (those who owned the property) of Ste. Genevieve. Others working on the property or in the agricultural fields belonging to property owners stayed in smaller dwellings, usually also on the property owner's houselot in town. This makes it more likely that the outbuilding analyzed in this study was associated with African slaves owned by the French family, and later a diverse group of servants working for the German Ziegler family. 
Having somewhat established that the outbuilding in question, because of the food remains, chimneys, glass windows, and the general lack of agricultural hardware (see Table 4.3), was not a barn or a stable, what then do the non-architectural or food related artifacts tell about the building's function or purpose?

\begin{tabular}{|c|c|c|c|c|}
\hline \multicolumn{5}{|c|}{$\begin{array}{l}\text { Data Table } 4.3 \text { Artifact Quantities and Percentages } \\
\text { from the Outbuilding by Occupation, with } \\
\text { Architectural, Animal Remains, and Plant Remains } \\
\text { Removed. }\end{array}$} \\
\hline \multirow{2}{*}{ Artifact Type } & \multicolumn{2}{|r|}{ Janis } & \multicolumn{2}{|r|}{ Ziegler } \\
\hline & $\#$ & $\%$ & $\#$ & $\%$ \\
\hline Ceramic & 18 & $15.4 \%$ & 73 & $34.6 \%$ \\
\hline Glass & 5 & $4.3 \%$ & 10 & $4.7 \%$ \\
\hline Metal & 86 & $73.5 \%$ & 113 & $53.6 \%$ \\
\hline Gun parts & 2 & $1.7 \%$ & 5 & $2.4 \%$ \\
\hline Whetstone & 1 & $0.9 \%$ & 0 & $0.0 \%$ \\
\hline Gastrolith & 5 & $4.3 \%$ & 10 & $4.7 \%$ \\
\hline Total & 117 & $100.0 \%$ & 210 & $100.0 \%$ \\
\hline
\end{tabular}

The artifacts make up seventeen functional categories which represent a wide array of different activities that took place during both occupations. The functional categories and their associated items can be located in Appendix. The nature of the activities - from lead shot production and hunting/weaponry to food storage and food serving and consumption-are wide-ranging and diverse. Table 4.4 shows an abbreviated functional comparison between the occupations with the architectural, animal remains, plant remains, and unidentified materials removed for a clearer idea of what activities (apart from those already discussed) were taking place around the structure. 


\begin{tabular}{|c|c|c|c|c|}
\hline \multicolumn{5}{|c|}{$\begin{array}{l}\text { Data Table } 4.4 \text { Functional Categories for the Outbuilding } \\
\text { without Construction and Maintenance, Animal Remains, Plant } \\
\text { Remains, and Unidentified. }\end{array}$} \\
\hline \multirow{2}{*}{ Functional Categories } & \multicolumn{2}{|c|}{ Janis } & \multicolumn{2}{|c|}{ Ziegler } \\
\hline & $\#$ & $\%$ & $\#$ & $\%$ \\
\hline Animal Related Hardware & 0 & $0.0 \%$ & 1 & $1.7 \%$ \\
\hline Domestic Fowl Production & 4 & $16.7 \%$ & 10 & $16.7 \%$ \\
\hline Health/Sanitation & 0 & $0.0 \%$ & 5 & $8.3 \%$ \\
\hline Hunting/weaponry & 1 & $4.2 \%$ & 5 & $8.3 \%$ \\
\hline Furnishings & 1 & $4.2 \%$ & 1 & $1.7 \%$ \\
\hline Food Serving and Consumption* & 8 & $33.3 \%$ & 21 & $35.0 \%$ \\
\hline Food Storage* & 0 & $0.0 \%$ & 1 & $1.7 \%$ \\
\hline Food Preparation* & 4 & $16.7 \%$ & 7 & $11.7 \%$ \\
\hline Tool & 2 & $8.3 \%$ & 4 & $6.7 \%$ \\
\hline Clothing & 0 & $0.0 \%$ & 5 & $8.3 \%$ \\
\hline Lead Shot Production & 1 & $4.2 \%$ & 0 & $0.0 \%$ \\
\hline Sewing & 1 & $4.2 \%$ & 0 & $0.0 \%$ \\
\hline Trade & 1 & $4.2 \%$ & 0 & $0.0 \%$ \\
\hline Other & 1 & $4.2 \%$ & 0 & $0.0 \%$ \\
\hline Total & 24 & $100.0 \%$ & 80 & $100.0 \%$ \\
\hline
\end{tabular}

*Represent minimum number of vessels

The highest number of artifacts within an area represents an activity or function most frequently practiced within the vicinity. Though the highest percentages in both the Janis and Ziegler occupations are objects related to food serving and consumption (small to medium bowls, saucers, cups, platters, and glass vessels) and other kitchen or food related activities (food preparation, seen through large bowls, and food storage, characterized by crocks, barrel bands, bottles, etc.), there are other functional groups that create the need to speculate further about the purpose of the building. The presence of artifacts related to possible animal hardware (L-shaped nail), 
hunting/weaponry (gunflint and lead shot), lead-shot production and the occasional trade good (catlinite fragment) all indicate a more diverse environment than is normally conceived of when discussing a kitchen. These functional categories could represent activities taking place on either the outside or the inside of the structure and could potentially help determine the primary (if there was a primary function) of the building itself.

Unfortunately, the collected materials could realistically fall under assemblages belonging to either a detached kitchen or slave quarter. The non-kitchen related activities (i.e., sewing, the clothing related objects, gastroliths, and/or hunting/weaponry categories) could be explained by the individuals in the structure doing other chores that needed to be accomplished over the space of a day. The whole assemblage might also represent what those individuals who were possibly living in the structure were doing in preparation for their own meals and in the evenings on their own time.

Finding the economic indicators that give a better idea of where, on the social and economic scale, those associated with the outbuilding could have been placed, will also aid, more concretely, in determining just who was living and/or working inside the structure. In this case, the best chance of finding such economic indicators is with the ceramic component of the assemblage. Though ceramics make up only a small part of the overall items recovered, they speak loudly-through type, decoration, and context-about the likely economic positions of those living within the outbuilding. Using Miller's (1980) economic level system to establish the economic range in which 
the ceramic pieces were located, the overall patterns of the individuals' ability to acquire goods start to emerge (see Table 4.5).

Within Miller's (1980) economic level system the $1^{\text {st }}$ level of ceramics represent the least expensive wares. Included in this category are undecorated refined white earthenwares, coarse red earthenwares, undecorated yellowwares, and stonewares. Most common among these after the 1820 s (the time period in which Miller focuses the most), "tend to be chamber pots, plates, bowls, and forms related to kitchen use" (Miller 1980:3).

The $2^{\text {nd }}$ level ceramics within Miller's economic levels are minimally decorated ceramics made "by minimally skilled operatives" (1980:3). "Types in this group include shell edge, sponge decorated, banded, mocha, and "common cable" (finger trailed slip). In all of these types, there is a fairly wide range in the decoration on one vessel compared to another of the same size and form. For example, two mocha bowls are never exactly alike" (Miller 1980:4). Because of the decorative effects, the ceramics within this level cost more than those within the $1^{\text {st }}$ level, but the array in differences of the decorations, even among matched sets, meant that the ceramics that fall into this category were still relatively cheap.

The $3^{\text {rd }}$ level is made up of wares that were hand painted with "motifs such as flowers, leaves, stylized Chinese landscapes or geometric patterns. With this group the painters needed to have enough skill to duplicate patterns so that sets of matched pieces could be assembled" (Miller 1980:4). The painted decorative effects are valued below only transfer printed wares and wares such as iron stone. 
The $4^{\text {th }}$ and last level within Miller's economic system is the most expensive. This level represents transfer printed ceramics. "With transfer printing it was possible to have intricately decorated and exactly matching pieces at a cost far below similarly hand painted pieces" (Miller 1980:4).

\begin{tabular}{|c|c|c|c|c|}
\hline \multicolumn{5}{|c|}{$\begin{array}{l}\text { Data Table } 4.5 \text { Economic scales associated with Ceramics for } \\
\text { the Outbuilding. }\end{array}$} \\
\hline \multirow{2}{*}{ Miller's Economic Levels } & \multicolumn{2}{|c|}{ Janis Vessel } & \multicolumn{2}{|c|}{ Ziegler Vessel } \\
\hline & $\#$ & $\%$ & $\#$ & $\%$ \\
\hline 1st Level & 9 & $75.0 \%$ & 16 & $55.2 \%$ \\
\hline 2nd Level & 1 & $8.3 \%$ & 6 & $20.7 \%$ \\
\hline 3rd Level & 1 & $8.3 \%$ & 2 & $6.9 \%$ \\
\hline 4th Level & 0 & $0.0 \%$ & 3 & $10.3 \%$ \\
\hline Unidentified & 1 & $8.3 \%$ & 2 & $6.9 \%$ \\
\hline Total & 12 & $100.0 \%$ & 29 & $100.0 \%$ \\
\hline
\end{tabular}

In the chart above (Table 4.5), we see, using Miller's levels of ceramic economic association based on decorative effects (1980), that unsurprisingly the $1^{\text {st }}$ level (or least expensive) on the scale has the highest proportion by far of the ceramics that were able to be determined. This means that most of the ceramics found within the outbuilding (mostly plain refined earthenwares - plain creamwares, whitewares, pearlwares-and coarse earthenwares such as stoneware and coarse red earthenware) were on the lower end of the economic scales. In fact, the only vessels within the Ziegler occupation that fall under the $4^{\text {th }}$ level (the most expensive ceramics) are transfer-printed or ironstone vessels that belong to functional categories linked to activities such as serving and consumption. These items may represent ceramics that were present because of the 
nature of the activities going on within the building (if it was a detached kitchen), they may have belonged to servants who saved money to obtain the more expensive ceramics, or they may be dishes that had been handed down to those living within the building as those living in the main house obtained newer sets. The ceramics also represent, as will be discussed, a means of seeing slaves vs. servants within the archaeological record-the more expensive ceramics were not present within the assemblage of the Janis occupation in the outbuilding, and, though they are still not seen in large numbers within the Ziegler occupation, they are present.

I also was interested in whether or not the trends seen in the Janis period would change as the new family settled in after 1833 . Groover (2003) found that the utilization of the homes and yard space around the Gibb farmstead in Knox County, Tennessee, changed as the cycles of the family changed. Furthermore, each new generation sought to make the property their own by changing aspects of the property integrated by previous owners. Though some modifications to the property would be expected as it changed from French hands into German (and morphed later into "American") hands, it appears, based on Table 4.6, as if no radical changes took place in and around the outbuilding from the time the Zieglers bought the property in 1833 to 1900. 


\begin{tabular}{|l|ll|ll|}
\hline \multicolumn{5}{|l|}{ Data Table 4.6 A Comparison in Percentages of } \\
Artifact Materials in the Outbuilding. \\
\hline \multirow{2}{*}{ Artifact type } & \multicolumn{3}{|l|}{ Janis } & \multicolumn{3}{l|}{ Ziegler } \\
\cline { 2 - 5 } & $\#$ & $\%$ & $\#$ & $\%$ \\
\hline Ceramic & 18 & $2.1 \%$ & 73 & $6.8 \%$ \\
Glass & 5 & $0.6 \%$ & 10 & $0.9 \%$ \\
Metal & 86 & $10.0 \%$ & 113 & $10.5 \%$ \\
Architectural & 357 & $41.5 \%$ & 370 & $34.2 \%$ \\
Plant Remains & 9 & $9.2 \%$ & 35 & $3.2 \%$ \\
Animal Remains & 308 & $35.8 \%$ & 465 & $43.0 \%$ \\
Gun parts & 2 & $0.2 \%$ & 5 & $0.5 \%$ \\
Gastrolith & 5 & $0.6 \%$ & 10 & $0.9 \%$ \\
\hline Total & 791 & $100 \%$ & 1081 & $100 \%$ \\
\hline
\end{tabular}

By looking at the artifacts associated with each occupational sequence, and searching for variations in percentages, changes in the activity around and inside the structure should have left a visible fingerprint in the material culture deposited after the Ziegler family bought the property. A chi square analysis indicates that the artifact distributions between occupations were significantly different from the Janis occupation to the Ziegler occupation and that the differences between the occupations were not due to chance alone (the degree of significance or $p$-value was 1.5e-7). The differences present between the occupations may reflect the shift in social conditions on the property when the Ziegler family made the choice to change the "help" for the property, moving from slaves to servants in 1833.

Another way to seek changes over time on the property is to look for identifiable change in who was working in which places within the confines of the building/property. One would expect, if a function of a particular place were to change over time that the ratios between artifacts associated with men, women and undetermined genders would 
also fluctuate. Tables 4.7 and 4.8 show the differences between the Zeigler occupation and the Janis occupation in artifacts associated with women, men, or undetermined genders.

\begin{tabular}{|c|c|c|c|c|c|}
\hline \multirow{2}{*}{ Functional Categories } & \multicolumn{2}{|c|}{ Janis } & \multicolumn{2}{|c|}{ Ziegler } & \multirow{2}{*}{ Gender } \\
\hline & $\#$ & $\%$ & \# & $\%$ & \\
\hline Animal Shoeing & 0 & $0.0 \%$ & 1 & $0.1 \%$ & Men \\
\hline $\begin{array}{l}\text { Construction and } \\
\text { Maintenance }\end{array}$ & 357 & $41.9 \%$ & 370 & $35.7 \%$ & Men \\
\hline Hunting/Weaponry & 1 & $0.1 \%$ & 5 & $0.5 \%$ & Men \\
\hline Tool & 2 & $0.2 \%$ & 4 & $0.4 \%$ & Men \\
\hline Lead Shot Production & 1 & $0.1 \%$ & 0 & $0.0 \%$ & Men \\
\hline Trade & 1 & $0.1 \%$ & 0 & $0.0 \%$ & Men \\
\hline Animal Remains & 308 & $36.2 \%$ & 465 & $44.8 \%$ & Women \\
\hline $\begin{array}{l}\text { Interior Design and } \\
\text { Decoration }\end{array}$ & 1 & $0.1 \%$ & 2 & $0.2 \%$ & Women \\
\hline $\begin{array}{l}\text { Serving and } \\
\text { Consumption }\end{array}$ & 2 & $0.2 \%$ & 19 & $1.8 \%$ & Women \\
\hline Storage & 4 & $0.5 \%$ & 11 & $1.1 \%$ & Women \\
\hline Preparation & 3 & $0.4 \%$ & 7 & $0.7 \%$ & Women \\
\hline Sewing & 0 & $0.0 \%$ & 1 & $0.1 \%$ & Women \\
\hline Unidentified & 87 & $10.2 \%$ & 101 & $9.7 \%$ & Undetermined \\
\hline $\begin{array}{l}\text { Domestic Fowl } \\
\text { Production }\end{array}$ & 5 & $0.6 \%$ & 10 & $1.0 \%$ & Undetermined \\
\hline Plant Remains & 79 & $9.3 \%$ & 35 & $3.4 \%$ & Undetermined \\
\hline Health/Sanitation & 0 & $0.0 \%$ & 2 & $0.2 \%$ & Undetermined \\
\hline Clothing & 1 & $0.1 \%$ & 4 & $0.4 \%$ & Undetermined \\
\hline Total & 852 & $100.0 \%$ & 1037 & $100.0 \%$ & \\
\hline
\end{tabular}




\begin{tabular}{|c|c|c|c|c|}
\hline \multicolumn{5}{|c|}{$\begin{array}{l}\text { Data Table } 4.8 \text { Gender Representations by Functional } \\
\text { Activity Associated Artifacts per Occupation } \\
\text { in/around the Outbuilding. }\end{array}$} \\
\hline \multirow{2}{*}{$\begin{array}{l}\text { Gender } \\
\text { Association }\end{array}$} & \multicolumn{2}{|c|}{ Janis } & \multicolumn{2}{|c|}{ Ziegler } \\
\hline & $\#$ & $\%$ & \# & $\%$ \\
\hline Women & 318 & $37.3 \%$ & 505 & $48.7 \%$ \\
\hline Men & 362 & $42.5 \%$ & 380 & $36.6 \%$ \\
\hline Undetermined & 172 & $20.2 \%$ & 152 & $14.7 \%$ \\
\hline Total & 852 & $100.0 \%$ & 1037 & $100.0 \%$ \\
\hline
\end{tabular}

As visible in the Table 4.8, the gender ratios between the Janis and Ziegler occupations at the outbuilding do not appear to differ much between occupations, but again, through chi square analysis, it became apparent that the proportion of women's items does increase over time (the degree of significance or $p$-value was 0.00000195 ). This by no means takes away from the typical rule of thumb that most archaeologists see consistently with German ethnicity within American contexts: that German immigrants do their best to quickly blend in with the people around them (Elliot and Elliot 2000), making no big splashes along the way. It may, however, show that while quiet and quick to fall in line publically, German immigrants may have, at least at times, quietly changed conditions at home to meet with key values concerning slavery. Support for this idea comes from the past in the way Mathias Ziegler, and later his son Francis Ziegler, discontinued and continued to discontinue the slave tradition that had been in place on the property before their purchase of it in 1833 . Whatever the reason, the facts remain: the patterns associated with the outbuilding-its use, its maintenance, its activities - stay consistent, with the exception of the "help," between owners. The 
changes, material culture wise, that take place in the outbuilding are small, and would have, most likely, remained changes made behind the scenes-not public demonstrations or representations of their "German" (or Bavarian) roots. The increase in female oriented objects may reflect the status quo of the genders working and/or living in the outbuilding. Census records for the periods in which the Ziegler family owned the property show a general increase of women living on the property after 1850. While at least some of the women within the census records from 1850 reflect members of the Ziegler family (at least six Ziegler women resided on the property at the time), there were an additional four women who were not Zieglers living on the property. There were also three Ziegler men and one non-Ziegler man also on the property in 1850 (US Census 1850). Likewise, in 1860, the US census shows the presence of one Ziegler man (no non-Ziegler men) and four Ziegler women (and five non-Ziegler women and girls)(US Census 1860). The census records that follow (up to the turn of the century) show similar results-with women outnumbering the men in the main house and on the property (US Census 1870 and 1880).

Through the food remains, functional categories and architectural materials located through archaeological investigations, we have determined the outbuilding present during the Janis-Ziegler occupations (from 1790 to 1900) to have been a structure built to house individuals and/or to cook in. I have discovered no significant change in the use or structure of the building from the Janis to the Ziegler inhabitation. It seems, in both occupations, that women are the ones most associated with the building, but men seem to have some type of presence within the structure as well. It 
appears, in the materials recovered, as though men had the majority of the artifacts because of the inclusion of "Construction and Maintenance." While men were likely responsible for building and maintaining the structure, most of that particular type of activity happened at once, when it was built. The artifacts related to day to day activities in the structure are those that suggest women are the ones most associated with the building. Ethnically speaking, the chances are good, based on economic considerations discovered through Miller's levels of ceramic economic association (1980) and through remaining historic documentation, that the inhabitants of the outbuilding were first slaves under the French occupation, then servants working for the German Ziegler family. Though the function of the building was a key goal in this study, the fact that the building could be a detached kitchen and/or slave or servant's quarters (or both) does not radically hurt how the assemblage might broaden our understanding of the people working or living within its confines. In either case, it was likely first that African slaves lived or worked in and around the building, followed, it seems, closely by the German family's servants (German and Irish).

\section{Comparison with the Main House}

Another critical aspect in this analysis is how the outbuilding fits within the bigger picture-how it compares with the Janis-Ziegler main household. Using data obtained by Hawkins (2007), it was fairly simple to come up with a general list of categories that describe, roughly, what type of materials are present within each of the occupation levels. To establish that the building was indeed used to house the main 
family, I looked at what types of artifacts were emerging from unit 110R30 Qu. 2. The remains of all the artifacts recovered from this particular unit can be seen below:

\begin{tabular}{|l|ll|ll|}
\hline \multicolumn{5}{|c|}{$\begin{array}{l}\text { Data Table 4.9 Janis and Ziegler Occupations for } \\
\text { both the Outbuilding and Main House. }\end{array}$} \\
\cline { 2 - 6 } Artifact Type & \multicolumn{3}{|c|}{ Janis } & \multicolumn{2}{c|}{ Ziegler } \\
\cline { 2 - 5 } Ceramic* & 38 & $16.7 \%$ & 41 & $\%$ \\
Glass & 8 & $3.5 \%$ & 12 & $5.4 \%$ \\
Metal & 13 & $5.7 \%$ & 32 & $14.5 \%$ \\
Architecture & 124 & $54.6 \%$ & 82 & $37.1 \%$ \\
Plant Remains & 20 & $8.8 \%$ & 7 & $3.2 \%$ \\
Animal Remains & 21 & $9.3 \%$ & 36 & $16.3 \%$ \\
Gun parts & 2 & $0.9 \%$ & 5 & $2.3 \%$ \\
Gastrolith & 1 & $0.4 \%$ & 6 & $2.7 \%$ \\
\hline Total & 227 & $100.0 \%$ & 221 & $100.0 \%$ \\
\hline \multicolumn{4}{|c}{$*$ Ceramic Sherd Count } \\
\hline
\end{tabular}

The animal remains associated with the outbuilding represented an assortment of different remains-eggshell, shell, and bone. The main house shows a more limited grouping of materials - with only bone present. The eggshell that represented a good proportion of the animal remains for the outbuilding in both the Janis (42\%) and Ziegler (47\%) periods was not represented at all within the artifacts associated with the main house. The presence of large mammal bones was noted more frequently for the main house deposits than for the outbuilding deposits, but more specific information must await the faunal analysis.

The importance of the main house is seen in its permanence. The main house was constructed in the French poteaux sur solle (post on sill) style, where the vertical 
wooden posts are placed into wooden sill beams that rest on limestone walls; this protects the wooden supports from subterranean elements that tend to induce rot quicker. As discussed above, this manner of construction-poteaux sur solle-tends to lengthen the time between the building of the structure and the need for upkeep and maintenance. This also makes the structure a more permanent part of the landscape, and thus more apt to remain standing for longer periods of time. Economically the main structure, though more immediately expensive, would have been more cost effective over longer periods of time because continual upkeep would be less imperative for the more prominent structure.

The functional categories associated with the main house also represent a plethora of activities (see Table 4.10): 


\begin{tabular}{|c|c|c|c|c|}
\hline \multicolumn{5}{|c|}{$\begin{array}{l}\text { Data Table } 4.10 \text { Functional Categories for the Main House with } \\
\text { Construction and Maintenance, Animal Remains, Plant Remains, } \\
\text { and Unidentified Removed (categories that Represent Ceramics are } \\
\text { tallied as Minimum Number of Vessels). }\end{array}$} \\
\hline \multirow{2}{*}{ Functional Categories } & \multicolumn{2}{|c|}{ Janis } & \multicolumn{2}{|c|}{ Ziegler } \\
\hline & $\#$ & $\%$ & $\#$ & $\%$ \\
\hline Domestic Fowl Production & 1 & $3.1 \%$ & 6 & $14.6 \%$ \\
\hline Health/Sanitation & 2 & $6.3 \%$ & 0 & $0.0 \%$ \\
\hline Hunting/weaponry & 2 & $6.3 \%$ & 5 & $12.2 \%$ \\
\hline Serving and Consumption & 21 & $65.6 \%$ & 24 & $58.5 \%$ \\
\hline Preparation & 1 & $3.1 \%$ & 1 & $2.4 \%$ \\
\hline Tool & 0 & $0.0 \%$ & 0 & $0.0 \%$ \\
\hline Clothing & 2 & $6.3 \%$ & 0 & $0.0 \%$ \\
\hline Sewing & 2 & $6.3 \%$ & 0 & $0.0 \%$ \\
\hline Interior Design & 0 & $0.0 \%$ & 1 & $2.4 \%$ \\
\hline Lead Shot Production & 0 & $0.0 \%$ & 1 & $2.4 \%$ \\
\hline Personal & 1 & $2.0 \%$ & 1 & $2.4 \%$ \\
\hline Trade & 0 & $0.0 \%$ & 2 & $4.9 \%$ \\
\hline Total & 50 & $100.0 \%$ & 41 & $100.0 \%$ \\
\hline
\end{tabular}

The functional categories with the highest proportions of artifacts in the main house assemblage, for both the Janis and Ziegler occupations are Serving and Consumption remains (Janis with $65.6 \%$ and Ziegler with 58.5\%) (Table 4.10). I found it interest ing that although there was a high proportion of goods associated with Food Serving and Consumption (small-medium bowls, saucers, cups, platters, glass vessels; mostly represented by refined ware types such as creamwares, pearlwares, and whitewares), there were no items whatsoever linked with Food Preparation for the Ziegler occupation and one Food Preparation associated artifact found within the Janis occupation around the main house. The lack of food preparation related artifacts around the main house suggests a lack in that particular activity in/around this location. 
Though the presence of other functional activities are minimal, the fact that they exist suggests that they also had a place within the realm of the main house and may reflect some of the less frequent activities (Table 4.11) that may have occurred nearby/inside from time to time.

\begin{tabular}{|c|c|c|c|c|c|c|c|c|}
\hline \multirow{2}{*}{\multicolumn{5}{|c|}{$\begin{array}{l}\begin{array}{l}\text { Data Table 4.11 Functional Categories for } \\
\text { (Ceramics Represented as Sherd Counts) } \\
\text { Construction and Maintenance and Unide }\end{array} \\
\end{array}$}} & & $\begin{array}{l}\text { Pla } \\
\text { cts }\end{array}$ & & unts \\
\hline & & & & & \multicolumn{4}{|c|}{ Ziegler } \\
\hline \multirow{2}{*}{$\begin{array}{l}\text { Functional } \\
\text { Categories }\end{array}$} & \multicolumn{2}{|c|}{ Outbuilding } & \multicolumn{2}{|c|}{ Main House } & \multicolumn{2}{|c|}{ Outbuilding } & \multicolumn{2}{|c|}{ Main House } \\
\hline & $\#$ & $\%$ & $\#$ & $\%$ & $\#$ & $\%$ & $\#$ & $\%$ \\
\hline Animal Shoeing & $\overline{0}$ & $0.0 \%$ & 0 & $0.0 \%$ & 1 & $1.3 \%$ & 0 & $0.0 \%$ \\
\hline $\begin{array}{l}\text { Domestic } \\
\text { Fowl Production }\end{array}$ & 4 & $19.0 \%$ & 1 & $2.9 \%$ & 10 & $12.7 \%$ & 6 & $8.2 \%$ \\
\hline Health/Sanitation & 0 & $0.0 \%$ & 2 & $5.7 \%$ & 5 & $6.3 \%$ & 0 & $0.0 \%$ \\
\hline Hunting/weaponry & 1 & $4.8 \%$ & 2 & $5.7 \%$ & 5 & $6.3 \%$ & 5 & $6.8 \%$ \\
\hline $\begin{array}{l}\text { Interior Design } \\
\text { and Decoration }\end{array}$ & 1 & $4.8 \%$ & 0 & $0.0 \%$ & 1 & $1.3 \%$ & 1 & $1.4 \%$ \\
\hline $\begin{array}{l}\text { Serving } \\
\text { and Consumption }\end{array}$ & 7 & $33.3 \%$ & 21 & $60.0 \%$ & 31 & $39.2 \%$ & 24 & $32.9 \%$ \\
\hline Storage & 1 & $4.8 \%$ & 0 & $0.0 \%$ & 17 & $21.5 \%$ & 0 & $0.0 \%$ \\
\hline Preparation & 1 & $4.8 \%$ & 1 & $2.9 \%$ & 0 & $0.0 \%$ & 1 & $1.4 \%$ \\
\hline Tool & 2 & $9.5 \%$ & 0 & $0.0 \%$ & 4 & $5.1 \%$ & 0 & $0.0 \%$ \\
\hline Clothing & 0 & $0.0 \%$ & 2 & $5.7 \%$ & 5 & $6.3 \%$ & 0 & $0.0 \%$ \\
\hline $\begin{array}{l}\text { Lead } \\
\text { Production }\end{array}$ & 1 & $4.8 \%$ & 0 & $0.0 \%$ & 0 & $0.0 \%$ & 1 & $1.4 \%$ \\
\hline Sewing & 1 & $4.8 \%$ & 2 & $5.7 \%$ & 0 & $0.0 \%$ & 0 & $0.0 \%$ \\
\hline Trade & 1 & $4.8 \%$ & 0 & $0.0 \%$ & 0 & $0.0 \%$ & 2 & $2.7 \%$ \\
\hline Personal & 0 & $0.0 \%$ & 1 & $2.9 \%$ & 0 & $0.0 \%$ & 1 & $1.4 \%$ \\
\hline Other & 1 & $4.8 \%$ & 3 & $8.6 \%$ & 0 & $0.0 \%$ & 32 & $43.8 \%$ \\
\hline Total & 21 & $100.0 \%$ & 35 & $100.0 \%$ & 79 & $100.0 \%$ & 73 & $100.0 \%$ \\
\hline
\end{tabular}

Table 4.11, without artifacts associated with Animal Remains, Plant Remains, Construction and Maintenance, provides for a better idea about the other, less well 
represented activities occurring around both buildings. Another curious difference between the outbuilding and the main house during the Janis period are the diversity of functions represented by the Janis outbuilding versus those represented by the main house. The assemblage from the main house had a majority (62.9\%) of its artifacts represented by functions connected to serving and consumption and preparation, while the activities associated with the outbuilding were more evenly divided (the same categories represented only $43 \%$ of the total) among other activities.

Another difference between the outbuilding and the main house during the Janis period was the higher percentages of artifacts connected to domestic fowl production. This indicates the outbuilding saw more activity dealing with geese and/or chickens than did the main structure. The higher percentages of gastroliths (the artifacts that made up the domestic fowl production category) may have occurred at the outbuilding due to the nature of the structure-if the structure was utilized as a detached kitchen/slave quarters (or both) and it was the slaves/servants preparing food and/or doing the fowl domestic work, then it would be expected that more evidence of this activity would be present in the outbuilding. Supporting this, the higher proportions of eggshell and higher proportions of food preparation ceramics found within the outbuilding compared to the main house indicate the building might have been utilized as a place to prepare meals for both the people living in the outbuilding, and those living in the main structure. 
Another way to search for differences that occur between the two structures over time is through the ceramics which provide a reliable economic indicator to judge who had access to higher quality, and thus more expensive, ceramics.

\begin{tabular}{|c|c|c|c|c|c|c|c|c|}
\hline \multirow{3}{*}{$\begin{array}{l}\text { Miller's } \\
\text { Economic } \\
\text { Levels }\end{array}$} & \multicolumn{4}{|c|}{ Janis MNV } & \multicolumn{4}{|c|}{ Ziegler MNV } \\
\hline & \multicolumn{2}{|c|}{ Outbuilding } & \multicolumn{2}{|c|}{ Main House } & \multicolumn{2}{|c|}{ Outbuilding } & \multicolumn{2}{|c|}{ Main House } \\
\hline & $\#$ & $\%$ & \# & $\%$ & \# & $\%$ & \# & $\%$ \\
\hline 1st Level & 9 & $75.0 \%$ & 10 & $55.6 \%$ & 16 & $55.2 \%$ & 5 & $26.3 \%$ \\
\hline 2nd Level & 1 & $8.3 \%$ & 3 & $16.7 \%$ & 6 & $20.7 \%$ & 2 & $10.5 \%$ \\
\hline 3rd Level & 1 & $8.3 \%$ & 1 & $5.6 \%$ & 2 & $6.9 \%$ & 3 & $15.8 \%$ \\
\hline 4th Level & 0 & $0.0 \%$ & 2 & $11.1 \%$ & 3 & $10.3 \%$ & 9 & $47.4 \%$ \\
\hline Unidentified & 1 & $8.3 \%$ & 2 & $11.1 \%$ & 2 & $6.9 \%$ & 0 & $0.0 \%$ \\
\hline Total & 12 & $100.0 \%$ & 18 & $100.0 \%$ & 29 & $100.0 \%$ & 19 & $100.0 \%$ \\
\hline
\end{tabular}

*Ceramics represented as minimum number of vessels

While looking at the economic levels associated with the ceramics found at each structure (Table 4.12) was helpful, it was in the comparison between the two structures that a definitive pattern emerged. It was clear through Table 4.12 based on the number of ceramics within each economic level in each occupation, that the residents living within the outbuilding during the Janis period had less ability to buy the most expensive wares (there were no representations of $4^{\text {th }}$ level-the most expensive-ceramics found within the outbuilding during the Janis occupation). For the Janis occupation of the main house, $11.1 \%$ of ceramics were in the $4^{\text {th }}$ level ceramics of Miller's (1980) economic scaling (still not a large presence of $4^{\text {th }}$ level wares, but this may represent François Janis' reluctance to buy new, fancy ceramics at the end of his lifetime, more than his 
ability to do so). Figures 4 and 5 depict one of the vessels recovered through archaeological excavation of the outbuilding. The vessels recovered, though found in the builder's trench of the outbuilding, most likely represent some of the expensive ceramics owned by the Janis family and disposed of during the process of building the outbuilding. A similar pattern emerged within the ceramic economic scales of the Ziegler occupation of the Main House. The higher economic index present during the Ziegler period may represent the owner's willingness to purchase ceramics on a more constant basis than the Janis family had been willing to do. Though the Ziegler family had money concerns, they may have been willing to spend money on ceramics in order to show their place within the social world of Ste. Genevieve, Missouri. Part of this may have also have been because of the presence of four adult single women living within the household as compared to the lone François Janis. 


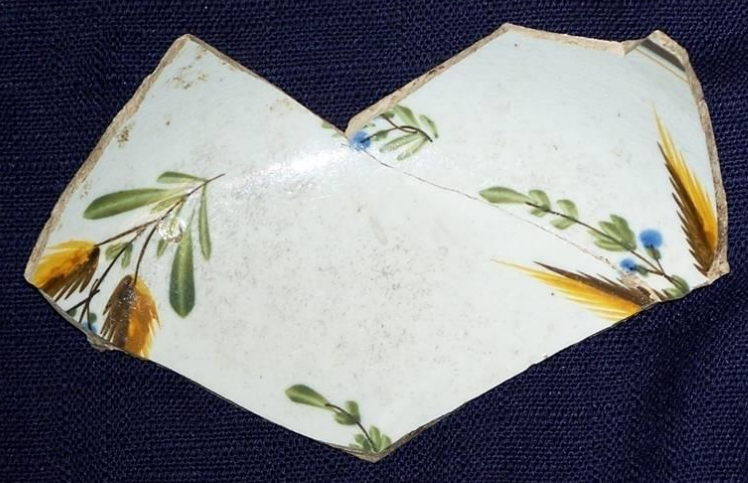

Figure 4. Image Illustrating Miller's $3^{\text {rd }}$ Economic Level Based off of Ceramic used by the Janis family. Hand-Painted Pearlware Bowl. Photograph taken by Dr. Elizabeth M. Scott.

Another possible explanation for the same results may come from conditions that the slaves/ servants found themselves working and/or living under. It is conceivable that the outbuilding under the Ziegler occupation revealed higher amounts of the more expensive ceramics because the servants living/working associated with the outbuilding were earning more money than the slaves living/working there when the Janis family lived on the property. 


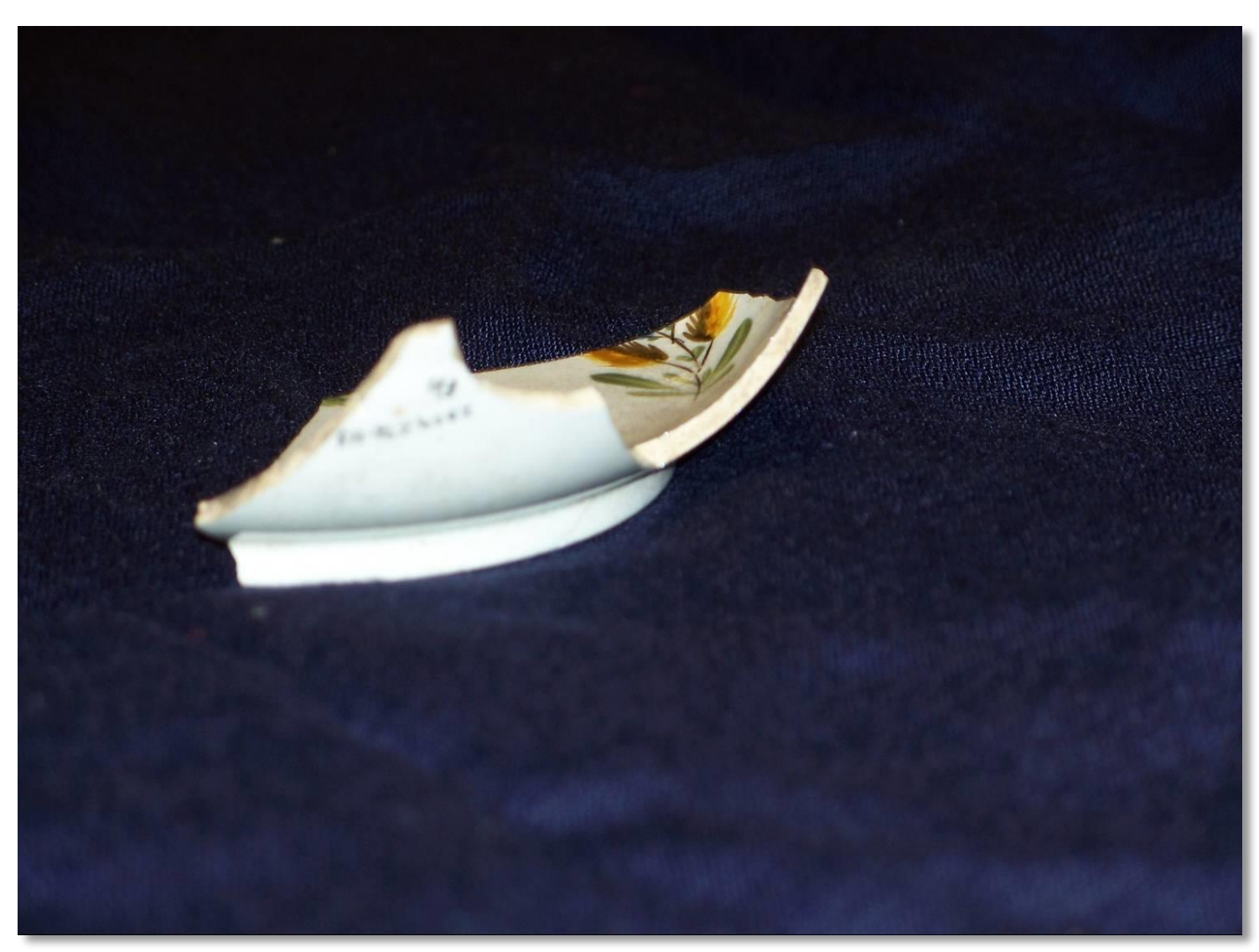

Figure 5. Image Illustrating Miller's $3^{\text {rd }}$ Economic Level Based off of Ceramic used by the Janis family. Hand-Painted Pearlware Bowl. Photograph taken by Dr. Elizabeth M. Scott.

Economically, the architectural remains also show the priorities of the owners. It may be stating the obvious, but the main house was more important to the Janis family as they were building it than the outbuilding was. The food remains were much more diverse from the assemblage that came from in/around the outbuilding than those recovered from the main house, which suggests that some form of food preparation was taking place within the outbuilding. The ceramics collected from both the outbuilding and the main house show a unique economic patterning that correlates with Janis/Ziegler ownership and the presence of slaves and later servants. This shows that 
those living within the main house consistently had the better and more expensive ceramics, while those living within the outbuilding used the cheaper wares. In comparing the main house with the outbuilding, in architecture, food remains, and ceramics, the economic picture becomes clearer, stating what was assumed-that the families living within the main home were of a higher social status than those living/working within the outbuilding-much more eloquently than mere words could have.

As with the outbuilding, it is important to understand the shifts in artifact use within the two occupational sequences at the main house (see Table 4.13).

\begin{tabular}{l}
\hline $\begin{array}{l}\text { Data Table 4.13 Artifact Quantities and Percentages by Occupation for the } \\
\text { Main House. }\end{array}$ \\
\cline { 2 - 5 } Artifact Type
\end{tabular}

*Ceramic Sherd Count

Glass, gun parts, and gastroliths remain similar through time, but ceramic and metal artifacts change rather dramatically between the two occupations. The presence of ceramics around the main house decreases in percentage between the Janis family occupation and that of the Ziegler family. One possibility for this may be found in the 
history of the families living within the home. The Janis family seems to have been financially stable for the time that they lived within the house. They moved to the area already established within the community (and had, in fact, been farming the Big Field in Ste. Genevieve during the time they had lived in Kaskaskia before actually moving across the Mississippi River). The Zieglers, however, had a pivotal change take place within the family not too long after they bought the property in 1833-the head of the household, Mathias Ziegler, died, leaving everything, including his debt, to his wife, Barbara and children. The smaller percentage of ceramics within the confines of the main house compared to those found within the Janis period may be the result of the Zieglers' lower ability to buy more goods. Another possibility may be visible in the wider amounts of goods recovered from the Ziegler occupation - the family may have chosen to tie available funds into other types of material culture.

The activity going on around the Janis-Ziegler home may have been fairly varied, but the gender associations connected to the functional activities, and whether these change over time-will also tell us a great deal about who was doing what types of things within these particular areas. Though the artifacts recovered from the one unit located near the main house may show bias in favor of activities carried out by women because of its location outside the domestic portion of the structure, the presence of domestically oriented goods (i.e., ceramics, animal remains, plant remains, sewing implements, etc.), suggests that it was also the location where domestic activities took place during both occupations. A comparison between the two occupational sequences should still reveal differences in gendered activities (Table 4.14). 


\begin{tabular}{|c|c|c|c|c|c|}
\hline \multirow[b]{2}{*}{ Functional Categories } & \multicolumn{2}{|c|}{ Janis } & \multicolumn{2}{|c|}{ Ziegler } & \multirow[b]{2}{*}{ Gender } \\
\hline & $\#$ & $\%$ & \# & $\%$ & \\
\hline $\begin{array}{l}\text { Construction } \\
\text { and Maintenance }\end{array}$ & 129 & $63.9 \%$ & 83 & $41.7 \%$ & Men \\
\hline Hunting/weaponry & 2 & $1.0 \%$ & 5 & $2.5 \%$ & Men \\
\hline Tool & 0 & $0.0 \%$ & 0 & $0.0 \%$ & Men \\
\hline Trade & 0 & $0.0 \%$ & 2 & $1.0 \%$ & Men \\
\hline Lead Shot Production & 0 & $0.0 \%$ & 1 & $0.5 \%$ & Men \\
\hline Animal Remains & 20 & $9.9 \%$ & 36 & $18.1 \%$ & Women \\
\hline $\begin{array}{l}\text { Serving and } \\
\text { Consumption* }\end{array}$ & 21 & $10.4 \%$ & 24 & $12.1 \%$ & Women \\
\hline Storage* & 0 & $0.0 \%$ & 0 & $0.0 \%$ & Women \\
\hline Preparation* & 1 & $0.5 \%$ & 1 & $0.5 \%$ & Women \\
\hline Sewing & 2 & $1.0 \%$ & 0 & $0.0 \%$ & Women \\
\hline $\begin{array}{l}\text { Interior Design } \\
\text { and Decoration }\end{array}$ & 0 & $0.0 \%$ & 1 & $0.5 \%$ & Women \\
\hline $\begin{array}{l}\text { Domestic Fowl } \\
\text { Production }\end{array}$ & 1 & $0.5 \%$ & 6 & $3.0 \%$ & Undetermined \\
\hline Plant Remains & 19 & $9.4 \%$ & 7 & $3.5 \%$ & Undetermined \\
\hline Clothing & 2 & $1.0 \%$ & 0 & $0.0 \%$ & Undetermined \\
\hline Health/Sanitation & 2 & $1.0 \%$ & 0 & $0.0 \%$ & Undetermined \\
\hline Other & 3 & $1.5 \%$ & 33 & $16.6 \%$ & Undetermined \\
\hline Total & 202 & $100.0 \%$ & 199 & $100.0 \%$ & \\
\hline
\end{tabular}

* Includes non-ceramic artifacts

\begin{tabular}{|l|rr|rr|rr|rr|}
\hline \multirow{2}{*}{ Data Table 4.15 A More Condensed Version of Table 4.14. } \\
\hline \multirow{3}{*}{ Gender } & \multicolumn{3}{|c|}{ Outbuilding } & \multicolumn{3}{c|}{ Main House } \\
\cline { 2 - 10 } Association & \multicolumn{2}{|c|}{ Janis } & \multicolumn{2}{|c|}{ Ziegler } & \multicolumn{2}{c|}{ Janis } & \multicolumn{2}{c|}{ Ziegler } \\
\cline { 2 - 10 } & $\#$ & $\%$ & $\#$ & $\%$ & $\#$ & $\%$ & $\#$ & $\%$ \\
Women & 409 & $46.6 \%$ & 549 & $52.0 \%$ & 44 & $21.8 \%$ & 62 & $31.2 \%$ \\
Men & 369 & $42.1 \%$ & 383 & $36.3 \%$ & 131 & $64.9 \%$ & 91 & $45.7 \%$ \\
Undet.* & 99 & $11.3 \%$ & 124 & $11.7 \%$ & 27 & $13.4 \%$ & 46 & $23.1 \%$ \\
\hline Total & 877 & $100.0 \%$ & 1056 & $100.0 \%$ & 202 & $100.0 \%$ & 199 & $100.0 \%$ \\
\hline
\end{tabular}

*Undet.. = Undetermined 
As seen in the Table 4.15, the gender associations through functional categories reveals a consistent range of gender-related artifacts found in the outbuilding between the Janis and Ziegler occupations. The gendered relations found at the main house, however, show some prominent changes over time. The changes that occur between the assemblages at the main house, between the two men's categories, is due to the largest amount of artifacts belonging to it-construction and maintenance. As discussed above, the construction style of the main house-poteaux-sur-sol (or post on sill)means more immediate work at the time of construction but requires less manual upkeep over longer periods of time. The reason that men are less visible within the archaeological record for the main house during the Ziegler period is because the architectural materials that showed their presence in the Janis period were less necessary during the Ziegler occupation. Other male activities are minimally represented within the assemblage for the main house, but they too exist (the next largest functional category relates to hunting/weaponry and may also be part of the processing of game for food).

The data associated with the main Janis-Ziegler home complements the data linked to the outbuilding inhabited most likely by slaves and servants. The fluctuation in function and economic status shows the variances between the owners and the workers interacting on the property. The examination of the gendered activities taking place in both the main house and the outbuilding during both periods has shown us how activities changed or remained the same between the occupations, and illustrates class through living space-the bigger and more permanent space sheltered the owners, 
while the space that needed continued upkeep housed those working for the family. The functional categories - the building blocks for many of the aspects of this studyhave helped to show who might have been working more (or less) within the areas in question - the main house and the outbuilding - and so provide a limited glimpse into the daily lives and interactions taking place within and around both the outbuilding and the main house and how the two structures might relate to the other in terms of work and status.

Though the artifacts from both the main house and the outbuilding may have had ethnic significance to the consumers buying and/or using them, the material culture presented no conclusive evidence that might show specific tendencies to buy objects that represented the buyer/user's origins. Ethnicity can be a tricky, and often impossible thing to track down within an assemblage. The most noticeable and prominent ethnically French aspect found at the property, through excavation and observation, is the structure that stands today. Though it may be a creolized French structure, it still is distinctly French enough to fit in well with the other French structures in Ste. Genevieve. Gunflints are also representative of French connections felt in the middle-Mississippi River valley, since those found at the site are all of French brown or honey-colored flint. They, along with the architecture, are some of the few remains left that explicitly shout "THE FRENCH WERE HERE!" The rest of the artifacts, though somewhat helpful in identifying other aspects of life during this period in Ste. Genevieve were mostly British in origin (purchased because they were relatively cheaper than French wares at the time) and so say little about the ethnic "French" living within the region. 
German immigrants have traditionally, in different regions, in different times, and in different contexts, been extremely difficult for archaeologists to pin down ethnically. They appear to move into a place, and blend as quickly as possible with those around them (Elliot and Elliot 2002). By looking at the material culture within the Ziegler occupations I have been able to determine that no objects recovered, at least from these units, show the presence of German ethnicity. It is in the proportions of objects, in comparison with other objects or contexts, in this case ceramics, where we see at least the main (Ziegler) family preferences at the site.

This is not to say that no change took place on the property between the Janis and the Ziegler periods, or that no indications exist that show the difference between the ethnically French and the ethnically German living within the region. We know through the records left to us, as well as through a small amount of material remains recovered through excavation, that change occurred. Small material changes here and there help determine familial preferences at the site. The installation of a floor or clapboards in the outbuilding (visible through the small, yet definite increase in nails found at the site during the Ziegler occupation), the difference in economic factors between the people working/living within the outbuilding during the Janis and Ziegler period, and the shift from slaves to servants within the outbuilding (represented in ceramics, architectural elements, the wider array of activities taking place within/around the outbuilding), and in the written materials. We know through documentation that the Zieglers discontinued the slave tradition on the property in 
1833 , and this may be the biggest indicator of ethnicity, short of the main structure itself, found to have occurred on the property.

\section{Summary}

The majority of the artifacts not related to food or architecture seem to be domestic in nature, significantly narrowing down the possibilities of the outbuilding's function. The chances are good, given the high proportion of domestic refuse, animal remains, and architectural remains, that the structure most likely represents a detached kitchen or living quarters, or even a multi-function building containing both a kitchen and quarters (to see other examples and discussion of detached kitchens also serving as slave or servant quarters see Stewart-Abernathy 2004).

The first way in which I sought change (or stability) in the use of the building was by looking at the artifacts themselves. I tried to keep the categories as general as possible, using material types (i.e., ceramic, glass, metal, food remains, etc.), rather than function to determine shifts in use of the structure. The general trends between the two periods were consistent, not changing much, and in all cases, represent less than a $10 \%$ shift between one occupation and the other.

The next way I tried to determine change between the occupations was through gender. I sought to see if there was a shift in objects oriented toward men vs. those generally associated with women and found, again, little remarkable difference between the two occupations. This tendency towards a similar use of the outbuilding also appeared in close parallels within the main house-the artifacts present were closely mirrored between the Janis and Ziegler occupation. The gender associations 
within the main house also represented little change between Janis ownership and that of the Ziegler family. 


\section{CHAPTER V}

\section{CONCLUSION AND RECOMMENDATIONS FOR FUTURE RESEARCH}

This study attempted to examine the function of the outbuilding as well as class, gender, and ethnic distinctions between the men and women living in the main JanisZiegler home and those living in the small outbuilding behind (to the west of) the main house during both the Janis and Ziegler occupations. Written documentation indicates that from 1790 to 1833 , slaves owned by the French Janis family occupied and labored at the site. Additionally, from 1833 to c. 1860, a combination of Americans, Irish, and Germans worked as servants to the succeeding German Ziegler family. This study also attempted to gain a better understanding of the dynamics between those living in the main house and those living in the outbuilding. This study hopes to have provided not only a better understanding of the social interactions of those living within the colonial and post-colonial Illinois country, but it should also act as a more generalized demonstration of the importance of material culture in understanding questions pertaining to identity and choice.

Overall, the artifacts indicated a somewhat wider variety of activities taking place in/around the outbuilding than around the main house for each of the corresponding periods of time. Though some bias might exist, due to the investigation 
of more physical space around the outbuilding than investigated around the main structure, the variety of functional activities associated with the outbuilding suggested, along with circumstantial evidence connected to architectural, food, and a wide selection of domestic remains (sewing goods, ceramics, clothing remains, etc.), that the outbuilding's original purpose and function was connected to kitchen or living space rather than activities associated with agricultural production.

The interpretation of the questions concerning class helped to provide one of the main ways of seeing slaves, and later, servants, in a semi-urban setting where almost all goods were coming from the same, or similar places-the British and later Americans on the east side of the Mississippi River. The residents of Ste. Genevieve, Missouri in the late eighteenth and nineteenth centuries had easier access to British made goods than those from France. They were closer, cheaper, and easier (and quicker) to obtain than those goods originating from France or other French hubs like Quebec or New Orleans. Because of this it is almost impossible to find anything that might represent French ethnicity within the assemblages examined within this study. This could represent a lack of good preservation of the material culture with ethnic associations, or it could show that residents within the community were less inclined to represent their heritage through durable items. Meals, as well as most articles of clothing, and many other pieces of culture (both long-lasting objects as well as nonpermanent aspects, such as language, religion, etc.) are often ways in which people describe (consciously or unconsciously) who they are and where they come from to the world around them; yet these are often the items/aspects of life that deteriorate first. 
Twiss (2007:2) writes: "food is an unusually powerful symbol of identity because foodways involve both the performance of culturally expressive behaviors and the literal incorporation of a material symbol." Sophie White also demonstrates the importance of less permanent articles of material culture, writing, "the clothed body-and the spatial context in which the act of dressing took place-played a specially nuanced role, for clothing itself was deployed both to signal and to construct identity" (White 2013:3).

Those actually living/working within the outbuilding were unidentifiable for the same reasons as mentioned above-they too were using the materials obtained primarily from British and American sources. However, the property owners-the Janis and the Zieglers - may be seen through the physical layout and changes made over time. The Janis family's French origins are represented through the French architectural design used in the construction of the structure. Despite the Janis family not living within the outbuilding, the style is still undeniably French-poteaux-en-terre. They built the structures found on the property in the ways that made sense to them-in the French manner with little to no input of the individuals who were associated most with the structure.

German settlers are notoriously difficult to spot in the archaeological record, blending in with other groups, it seems, as quickly as possible (Elliot and Elliot 2000). But in this instance the Ziegler's German ethnicity may be visible in a less direct manner. The choice between slaves and servants may have been out of necessity, since slaves were expensive, but it might also represent a tendency of German immigrants to avoid slavery. Though less of a public statement than clothing or personal items from 
Germany, the change from slaves to servants within a region where slavery was not only accepted, but also a means of representing a family's social position, shows that ethnicity can be seen in more nuanced ways. In addition, the small physical adaptations (the possible clapboards/new floor) made to the outbuilding and the documentation showing a change from a slave-based system to servants, can perhaps be interpreted with ethnicity in mind.

The economic scaling of the ceramics found within the Janis occupation show a difference between the main house and the outbuilding. The Janis family had nicer wares than those living/working within the outbuilding. They also inhabited and worked within the larger structure, while those living/working within the outbuilding had a less permanent, and less comfortable, space to use on a daily basis. The Ziegler occupation ceramics also demonstrated that the people living/working within the outbuilding had better access (financially) to some (not much) of the nicer wares such as transfer printed pearlwares and whitewares. There is still a noticeable difference in the hierarchical placement of individuals in the main house and the outbuilding - the Ziegler family had a much higher percentage of transfer printed objects within the assemblage recovered than those living/working within the outbuilding. Those living/working within the outbuilding also continued the Janis pattern of the "help" living/working in the outbuilding while the main family occupied the main house. It seems, as an overall trend, however, as if the balance between the main family and the workers on the property moved as time progresses, at least in part, a little closer to the fulcrum.

Overall, I hope to have provided a means of seeing into the past of Ste. Genevieve, Missouri, through the examination of a particular houselot from the late 1790 s to the late 
1800s. This study has attempted to provide not only a glimpse of the main structure or family-which, though fascinating in their own right, tells little of the relationships taking place on the property. It attempts to show the dynamics between peoples of difference classes, ethnicities, and genders in a continuously changing and evolving community.

\section{Recommendations for Future Research}

Lots of work has been accomplished in the world of archaeology and though I may be a humble Master's student, I will dare to make five suggestions for future research within my chosen field for future generations of humble students to come. These suggestions (and they are just that...suggestions), it is hoped, will help fill in a few of the gaps in our understanding of the world, the United States, and it's very diverse "people". The suggestions will start off broad and will narrow in scope as I progress. They include: 1.) more historical archaeological research within the Midwest; 2.) a more intensive look into the French presence in the Middle Mississippi River Valley; 3.) a more extensive examination of outbuildings within the region-especially outbuildings with domestically oriented purposes; 4.) A more comprehensive study of the Janis-Ziegler house, especially around the outbuilding discussed within this study. Finally, 5.) A faunal analysis should be completed to better understand how each occupation's diet fluctuated in relation to ethnicity and class.

1. More historical archaeological research within the Midwest.

This is the first (and broadest) of my recommendations for future research. The processes that shaped our modern world-contact, colonialism and post-colonial 
interaction-developed differently within different regions of North America and each region deserves to be studied more completely to gain a more complete understanding of how these periods in North American history have effected and are still effecting American culture, government policies, and our interactions with the rest of the world. It has always been a place of contact, congregation, trade and settlement-it was (and remains today) a cross roads connecting the east and the west, the north and the south. It is vital to the understanding of both the region and the country that more archaeological research be completed within the Midwest to fill in the many gaps existing in our understanding of our and our country's past. I am not suggesting work be done in a vacuum of nothingness. There has been archaeological investigations within the region that have contributed greatly to archaeological research as a whole. I am suggesting more work be done to better understand how singular sites fit into the whole narrative.

2. A more intensive look into the French presence in the Middle Mississippi River Valley.

Though some archaeological work has been completed (as discussed earlier in the study) on French inhabitants within the Middle Mississippi River valley, more research has been undertaken in the Lower and Upper Mississippi River valleys. Of the few French sites that have been investigated within the Middle Mississippi River Valley, most were located east of the Mississippi River. The French world west of the river was a massively different place than the one to the east. At least it was after 1765 (when the British officially took over the eastern portion of the Illinois country). Towns on the 
western banks of the Mississippi River, such as St. Louis, St. Girardeau, and Ste.

Genevieve, have a lot, still, to offer investigators interested in French North America.

The fact that these communities remain active communities today shows that their populations found ways to adapt and/or negotiate cultural identities as the dynamics of the populations shifted around them. Investigations therein may provide insights into how diverse populations build and shape the character of a community. In investigating those French settlements that did not survive the rigors of time (i.e. New Bourbon, etc.) we may discover the life (and death) cycles of such villages and how they compare to similar cycles within the Anglo-American atmosphere. Regardless of what questions are chosen, more investigation should take place to better understand the players in the story of North American colonialism.

3. More work of outbuildings within the region during the French and the transitional periods.

As with the previous recommendation, outbuildings within the region have seen little archaeological research focused primarily on them. While ultimately it would be great to see more archaeological investigation of French outbuildings, more investigations period of outbuildings needs to take place within the Midwest to better understand how the use of outbuildings differ between separate ethnicities and in different periods of time. More data in this direction may present a clearer pattern for the differentiation of detached kitchens and/or slave/servants quarters. The study of outbuildings within archaeological study may reveal a great variety in research questions and may focus on the outbuilding's placement (town vs. farmstead, etc.), any 
number of combinations of ethnicity and relationships between slaves and owners, and may provide a more detailed understanding of the roles that men and women (both the property owners and the "help") had outside of the main household.

4. More excavation of the Janis-Ziegler property (esp. by the outbuilding)

Of all of my recommendations I would like to see this particular one pursued the most. The outbuilding discussed in this study has only partially been explored in previous archaeological excavations. Further excavation of the site may furnish more information that may lead to a more detailed idea of the functional activities taking place in/around the outbuilding, a better vision of those living/working within the structure, and more of an idea of the structure's dimensions in relation to the house and the property.

\section{Faunal analysis}

Food and its presentation has always been a noticeable (though not always permanent) means of representing ethnicity, class and gender. Finally, the faunal remains found associated with the Janis-Ziegler outbuilding should be analyzed to more completely understand the dynamics of those living/working within the outbuilding to those residing in the main structure. 


\section{REFERENCES}

Armstrong, Douglas V.

1990 The Old Village and the Great House: An Archaeological and Historical

Examination of Drax Hall Plantation, St. Ann's Bay, Jamaica. University of Ilinois

Press, Chicago.

1999 Archaeology and Ethnohistory of the Caribbean Plantation. In I, Too, Am

America: Archaeological Studies of African-American Life, edited by Theresa

Singleton, pp. 173- 192. University of Virginia Press, Charlottesville.

Armstrong, Douglas V., Mark Hauser, David W. Knight and Stephan Lenik

2009 Interpreting the Late Eighteenth-Century Cultural Landscape of St. John, Danish

West Indies Using an Archaeological GIS. International Journal of Historical

Archaeology 13:94-1111.

Ascher, Robert, and Charles H. Fairbanks

1971 Excavations of a Slave Cabin: Georgia, U.S.A. Historical Archaeology 5:3-17.

Alvord, Clarence Walworth

1920 The Illinois Country 1673-1818. Illinois Centennial Commission, Springfield, Illinois.

Baumann, Timothy, Andrew Hurley, and Lori Allen

2008 Economic Stability and Social Identity: Historic Preservation in Old North St. Louis. Historical Archaeology 42(1)70-87.

Brighton, Stephen A.

2011 Middle Class Ideologies and American Respectability: Archaeology and the Irish Immigrant Experience. International Journal of Historical Archaeology 15:30-50.

Casella, Eleanor Conlin

2000 Bulldaggers and Gentle Ladies: Archaeological Approaches to Female Homosexuality in Convict Era Australia. In Archaeologies of Sexuality, edged by Robert A. Schmidt and Barbara L. Voss, pp. 143-159. Routledge, London, England. 
Chapais, Thomas

1914 The Great Intendant: A Chronicle of Jean Talon in Canada 1665-1672. Glasgow, Brook \& Company, Toronto.

Clites, Elizabeth

2009 Quarters in Comparison: The Fairfield Quarter in a Temporal and Geographical Context. African Diaspora Archaeology March Newsletter.

Cox, Matthew A.

2009 Living Beyond Their Means: An Archaeological Investigation of Consumption

Patterns at the Janis-Ziegler Site (23SG272). Master's thesis, Department of

Sociology \& Anthropology, Illinois State University, Normal.

Deagan, Kathleen

1983 The Mestizo Minority: Archaeological Patterns of Intermarriage. In Spanish St. Augustine: The Archaeology of a Colonial Creole Community, edited by Kathleen Deagan, pp. 99-124. Academic Press, New York.

Deetz, James

1977 In Small Things Forgotten. Doubleday, Garden City.

Delle, James A.

2001 Race, Missionaries, and the Struggle to Free Jamaica. In Race and the

Archaeology of Identity, edited by Charles E. Orser Jr., pp. 177-207. University of Utah Press, Salt Lake City.

2008 An Archaeology of Modernity in Colonial Jamaica. Archaeologies: Journal of the World Archaeological Congress 4(1):87-109.

Denevan, William M.

1992 The Pristine Myth: The Landscape of the Americas in 1492. Annals of the Association of American Geographers 82(3):369- 385.

Dethlefsen, Edwin and James Deetz

1966 Death's Heads, Cherubs, and Willow Trees: Experimental Archaeology in Colonial Cemeteries. American Antiquity 31(4):502-510.

Edwards, Jay D.

2006 Creole Architecture: A Comparative Analysis of Upper and Lower Louisiana and Saint Domingue. International Journal of Historical Archaeology 10(3):241-271.

Edwards-Ingram, Ywone

2001 African American Medicine and the Social Relations of Slavery. In Race and the Archaeology of Identity, edited by Charles E. Orser, Jr., pp. 34-53. University of Utah Press, Salt Lake City. 


\section{Ehrhardt, Kathleen L.}

2010 Problems and Progress in Protohistoric Period Archaeology in the Illinois

Country since Calumet and Fleur-de-lys. Illinois Archaeology 22(1):256-287.

Ekberg, Carl J.

1996 Colonial Ste. Genevieve: An Adventure on the Mississippi Frontier. The Practice Press, Tucson, Arizona.

1998 Colonial Ste. Genevieve: An Adventure on the Mississippi Frontier, second edition. The Practice Press, Tucson.

Elliott, Rita F., and D. T. Elliott

2000 Guten Tag Bubba: Germans in the Colonial South. In Colonial Adaptations to the New World: A View from Georgia and the Carolinas, edited by J. Joseph, III, and M. Zierden, pp. 79-92. University of Alabama Press, Tuscaloosa.

Epperson, Terence W.

1999 Constructing Difference: The Social and Spatial Order of the Chesapeake Plantation. In I, Too, Am America: Archaeological Studies of African-American Life, edited by Theresa Singleton, pp. 159- 172. University of Virginia Press, Charlottesville.

Evans, Mark L.

2001 The Commandant's Last Ride. Ten-Digit Press, Cape Girardeau.

Ferguson, Leland

1980 Looking for the "Afro" in Colono-Indian Pottery." In Archaeological Perspectives on Ethnicity in America, edited by Robert L. Schuyler, pp. 14-28. Baywood, Farmingdale, New York.

1991 Struggling with Pots in Colonial South Carolina. In The Archaeology of Inequality, edited by R. H. McGuire and R. Paynter, pp. 28-39. Oxford Press, Blackwell.

Franklin, Maria

2001 The Archaeological Dimensions of Soul Food: Interpreting Race, Culture, and Afro-Virginian Identity. In Race and the Archaeology of Identity, edited by Charles E. Orser Jr., pp. 88-107. University of Utah Press, Salt Lake City.

Franklin, Maria and Garrett Fesler

1999 The Exploration of Ethnicity and the Historical Archaeological Record. In Historical Archaeology, Identity Formation, and the Interpretation of Ethnicity, edited by Maria Franklin and Garrett Fesler, pp. 1-10. Colonial Williamsburg Research Publications, Williamsburg.

2001 The Archaeological Dimensions of Soul Food: Interpreting Race, Culture, and Afro-Virginian Identity. In Race and the Archaeology of Identity, edited by Charles E. Orser Jr., pp. 88-107. University of Utah Press, Salt Lake City. 
Franzwa, Gregory M.

1998 The Story of Old Ste. Genevieve: An Account of an Old French Town in Upper Louisiana; its People and their Homes, sixth edition. Patrice Press Inc., Tucson, Arizona.

Gibb, James G. and Julia A. King

1991 Gender, Activity Areas, and Homelots in the 17th-Century Chesapeake Region. Historical Archaeology 25(4):109-131.

Gitlin, Jay

2010 The Bourgeois Frontier: French Towns, French Traders, and American Expansion. Yale University Press, New Haven.

Green, Lance K.

2011 Ethnicity and Material Culture in Antebellum North Carolina. Southeastern Archaeology 30(1):64-78.

Groover, Mark D.

2003 An Archaeological Study of Rural Capitalism and Material Life: The Gibbs Farmstead in Southern Appalachia, 1790-1920. Kluwer Academic, New York.

Gums, Bonnie

1988 Archaeology at French Colonial Cahokia. Illinois Historic Preservation Agency, Springfield.

Handler, Jerome S., Frederick W. Lange, and Charles E. Orser, Jr.

1979 Carnelian Beads in Necklaces from a Slave Cemetery in Barbados, West Indies.

Ornament 4(2):15-18.

Hawkins, Meredith

2007 The Janis-Ziegler Site (23SG272): The Archaeological Investigation of a Houselot in a French Colonial Village. Master's thesis, Department of Sociology \& Anthropology, Illinois State University, Normal.

Heath, Barbara J.

1999a Buttons, Beads, and Buckles: Contextualizing Adornment Within the Bounds of Slavery. In Historical Archaeology, Identity Formation, and the Interpretation of Ethnicity, edited by Maria Franklin and Garrett Fesler, pp. 47-69. Colonial Williamsburg Research Publications, Williamsburg.

1999b "Your Humble Servant": Free Artisans in the Monticello Community. In I, Too, Am America: Archaeological Studies of African-American Life, edited by Theresa Singleton, pp. 192- 217. University of Virginia Press, Charlottesville. 
Horning, Audrey J.

1999 In Search of a "Hollow Ethnicity": Archaeological Explorations of Rural Mountain Settlement. In Historical Archaeology, Identity Formation, and the Interpretation of Ethnicity, edited by Maria Franklin and Garrett Fesler, pp. 121-138. Colonial Williamsburg Research Publications, Williamsburg.

Houck, Louis (editor)

1909 The Spanish Regime in Missouri, vol. 2. R.R. Donnelley, Chicago.

Keene, David J.

2002 Beyond Fur Trade: The Eighteenth Century Colonial Economy of French North America As Seen From Fort De Chartres in the Illinois Country. Ph.D. dissertation, University of Wisconsin-Madison, Madison, department of Anthropology, Wisconsin. ProQuest.

Kelly, Kenneth G.

2004 The African Diaspora Starts Here: Historical Archaeology of Coastal West Africa. In African Historical Archaeologies, edited by Andrew M. Reid and Paul J. Lane pp. 219-241. Kluwer Academic/Plenum Publishers, New York.

Kern, Susan A.

1999 Where did the Indians Sleep?: An Archaeological and Ethnohistorical Study of Mid-Eighteenth-Century Piedmont Virginia. In Historical Archaeology, Identity Formation, and the Interpretation of Ethnicity, edited by Maria Franklin and Garrett Fesler, pp. 31-46. Colonial Williamsburg Research Publications, Williamsburg, Virginia.

Kimball-Brown, Margaret

1991 Documents and Archaeology in French Illinois. In French Colonial Archaeology: The Illinois Country and the Western Great Lakes, edited by John A. Walthall, pp. 78-84. University of Illinois Press, Urbana.

Kuehn, Steven R.

2010 Domestic Dining at French Colonial Sites in the American Bottom: Evidence from the Trotier (11S861) and Jarrot Nordique (11S1741) sites in French Cahokia. Illinois Archaeology 22(1): 227-239.

Jackson, Thomas L.

1994 Pounding Acorn: Women's Production as Social and Economic Focus. In Engendering Archaeology, edited by Joan M. Gero and Margaret W. Conkey, pp. 301-325. Basil Blackwell, Oxford.

Leone, Mark P. 
1984 "Interpreting Ideology in Historical Archaeology: The William Paca Garden in Annapolis, Maryland". In Ideology, Power and Prehistory, edited by Daniel Miller and Christopher Tilley. Cambridge University Press, Cambridge.

Leone, Mark P. and Gladys-Marie Fry with assistance from Timothy Ruppel

2001 Spirit Management among Americans of African Descent. In Race and the Archaeology of Identity, edited by Charles E. Orser Jr., pp. 143-157. University of Utah Press, Salt Lake City.

Mac Sweeney, Naoíse

2009 Beyond Ethnicity: The Overlooked Diversity of Group Identities. Journal of Mediterranean Archaeology 22(1):101-126.

Matthews, Christopher N.

2001 Political Economy and Race: Comparative Archaeologies of Annapolis and New Orleans in the Eighteenth Century. In Race and the Archaeology of Identity, edited by Charles E. Orser Jr., pp. 71-87. University of Utah Press.

Mazrim, Robert

2007 The Sangamon Frontier: History \& Archaeology in the Shadow of Lincoln. University of Chicago Press, Chicago.

2010 A Brief Summary of French Domestic Site Archaeology in Illinois, 1730-1800. Illinois Archaeology 22(1):148-165.

2011 At Home in the Illinois Country: French Colonial Domestic Site Archaeology in the Midwest 1730-1800. Illinois State Archaeological Survey, Champaign.

McGuire, Randall H. and Paul Reckner 2002 The Unromantic West: Labor, Capital and Struggle. Historical Archaeology 36(3): 44-58.

Metz, John

1999 Industrial Transition and the Rise of a "Creole" Society in the Chesapeake, 16601725. In Historical Archaeology, Identity Formation, and the Interpretation of Ethnicity, edited by Maria Franklin and Garrett Fesler, pp. 11- 30. Colonial Williamsburg Research Publications, Williamsburg.

Miller, George L.

1980 Classification and Economic Scaling of $19^{\text {th }}$ Century Ceramics. Historical Archaeology 14(1):1-40.

Mrozowski, Stephen A., Maria Franklin, and Leslie Hunt 2008 Archaeobotanical Analysis and Interpretations of Enslaved Virginian Plant Use at Rich Neck Plantation (44WB52). American Antiquity 73(4)699-728. 
Mullins, Paul R.

2001 Racializing the Parlor: Race and Victorian Brick-a-Brack Consumptuion. In Race and the Archaeology of Identity, edited by Charles E. Orser Jr., pp. 158-176. University of Utah Press, Salt Lake City.

Neiman, Fraser D.

1999 Dimensions of Ethnicity. In Historical Archaeology, Identity Formation, and the Interpretation of Ethnicity, edited by Maria Franklin and Garrett Fesler, pp. 139149. Colonial Williamsburg Research Publications, Williamsburg.

Norris, F. Terry

1991 Ste. Genevieve, a French Colonial Village in the Illinois Country. In French Colonial Archaeology: The Illinois Country and the Western Great Lakes, edited by John A. Walthall, pp. 133-148. University of Illinois Press, Urbana.

Orser, Charles E., Jr.

1996 A Historical Archaeology of the Modern World. Springer, New York.

1998 The Archaeology of the African Diaspora. Annual Review of Anthropology 27:63-

82.

2001 Race and the Archaeology of Identity in the Modern World. In Race and the Archaeology of Identity, edited by Charles E. Orser Jr., pp. 1-13, University of Utah, Salt Lake City.

2007 The Archaeology of Race and Racialization in Historic America. University Press of Florida, Gainesville.

Otto, John Solomon

1984 Cannon's Point Plantation, 1794-1860: Living Conditions and Status Patterns in the Old South. Academic Press, New York.

Paynter, Robert

1988 Steps to an Archaeology of Capitalism: Material Change and Class Analysis. In The Recovery of Meaning: the Historical Archaeology of the Eastern United States, edited by Mark P. Leone and Parker B. Potter, Jr., pp. 407-433. Smithsonian Institution Press, Washington, D.C.

2001 The Cult of Whiteness in Western New England. In Race and the Archaeology of Identity, edited by Charles E. Orser Jr., pp. 125-142. University of Utah Press, Salt Lake City.

Prown, Jules David

1982 Mind in Matter: An Introduction to Material Culture Theory and Method. Winterthur Portfolio 17(1):1-19.

Samford, Patricia 
1999 "Strong is the Bond of Kinship": West African-Style Ancestor Shrines and Subfloor Pits on African-American Quarters. In Historical Archaeology, Identity Formation, and the Interpretation of Ethnicity, edited by Maria Franklin and Garrett Fesler, pp. 71-92. Colonial Williamsburg Research Publications, Williamsburg, Virginia.

2004 Engendering Enslaved Communities on Virginia's and North Carolina's

Eighteenth- and Nineteenth-Century Plantations. In Engendering African

American Archaeology, edited by Jillian E. Galle and Amy L. Young, pp. 151-175. University of Tennessee Press, Knoxville.

Schroeder, Walter A.

2002 Opening the Ozarks: A Historical Geography of Missouri's Ste. Genevieve District, 1760-1830. University of Missouri Press, Columbia.

Scott, Elizabeth M. 1991 A Feminist Approach to Historical Archaeology: Eighteenth-Century Fur Trade Society at Michilimackinac. Historical Archaeology 25(4):42-53. 2001a Food and Social Relations at Nina Plantation. American Anthropologist 103(3):671-691.

2001b An Indolent Slothfull Set of Vagabonds: Ethnicity and Race in a Colonial FurTrading Community. In Race and the Archaeology of Identity, edited by Charles E. Orser Jr., pp. 14-33. University of Utah Press, Salt Lake City.

Scott, Elizabeth M. and Donald P. Heldman

2010 A French Descendant Community after the Fall of New France: Archaeology in Nouvelle Ste. Genevieve, 1780-1880. Le Journal 26(1):1-13.

Singleton, Theresa A.

2001 Class, Race and Ethnicity among Free Blacks in the Antebellum South. In Race and the Archaeology of Identity, edited by Charles E. Orser Jr., pp. 196-208. University of Utah Press.

Starbuck, David R.

1994 The Identification of Gender at Northern Military Sites of the Late $18^{\text {th }}$ Century. In Those of Little Note: Gender, Race, and Class in Historical Archaeology, edited by Elizabeth M. Scott, pp. 116-128. The University of Arizona Press, Tucson.

Steen, Carl

1999 Stirring the Ethnic Stew in the South Carolina Backcountry: John de la Howe and Lethe Farm. In Historical Archaeology, Identity Formation, and the Interpretation of Ethnicity, edited by Maria Franklin and Garrett Fesler, pp. 93-120. Colonial Williamsburg Research Publications, Williamsburg.

Ste. Genevieve County Deeds 
1833 Division of François Janis Estate, Jan 21, 1833. Ste. Genevieve Deed Book D, pp. 366-375. Office of the Recorder of Deeds, Ste. Genevieve County Courthouse, Ste. Genevieve.

Stewart-Abernathy, Leslie

1986 Urban Farmsteads: Household Responsibilities in the City. Historical Archaeology 20(2):5-15.

2004 Separate Kitchens and Intimate Archaeology: Constructing Urban Slavery on the Antebellum Cotton Frontier in Washington, Arkansas. In Household Chores and Household Choices: Theorizing the Domestic Sphere in Historical Archaeology, edited by Kerri S. Barile and Jamie C. Brandon, pp. 51-74. University of Alabama Press, Tuscaloosa.

Stine, Linda France, Melanie A. Cabak, and Mark D. Groover 1996 Blue Beads as African-American Cultural Symbols. Historical Archaeology $30(3): 49-75$.

Trimble, Michael K., Teresita Majewski, Michael J. O'Brien, and Anna L. Price 1991 Frontier Colonization of the Saline Creek Valley. In French Colonial Archaeology: The Illinois Country and the Western Great Lakes, edited by John A. Walthall, pp. 163-188. University of Illinois Press, Urbana.

Twiss, Katheryn C.

2007 We are what we eat. In The Archaeology of Food and Identity, edited by Katheryn C. Twiss, pp. 1-15. Southern Illinois University, Carbondale.

US Bureau of Census

1850 Federal Census for City of Ste. Genevieve in the County of Ste. Genevieve, State of Missouri. August 1850.

1860 Federal Census for City of Ste. Genevieve in the County of Ste. Genevieve, State of Missouri. June 1860.

Venet, Julien

2008 Petitions from Peripheries of Empire: Louisiana and Québec. American Review of Canadian Studies 38(4):495-512.

Voss, Barbara L.

2006 Engendered Archaeology: Men, Women, and Others. In Historical Archaeology, edited by Martin Hall and Stephen W. Silliman, pp. 107-127. Blackwell Publishing, Malden, Massachusetts.

Wall, Diana diZerega 1994 The Archaeology of Gender: Separating the Spheres in Urban America. Plenum Press, New York. 
Walthall, John A.

1991 Faience in French Colonial Illinois. Historical Archaeology 25(1):80-105.

Walthall, John A. and Thomas E. Emerson

1991 French Colonial Archaeology. In French Colonial Archaeology: The Illinois

Country and the Western Great Lakes, edited by John A. Walthall, pp. 1-13.

University of Illinois Press, Urbana, Illinois.

Waselkov, Gregory A.

1997 The Archaeology of French Colonial North America. Society for Historical Archaeology Guides to Historical Archaeological Literature 4:2-41.

Weik, Terrance

2004 Archaeology of the African Diaspora in Latin America. Historical Archaeology 38(1):32-49.

Wesler, Kit W.

1999 Archaeological test excavations at the Delassus-Kern House, Ste. Genevieve, Missouri. Ohio Valley Historical Archaeology 14:67-88.

2004 Excavations at the Felix Vallé and Benjamin Shaw Houses, Ste. Genevieve,

Missouri, 1998-1999. Murray State University. Submitted to the Felix Vallé State

Historic Site. Copies available from the Felix Vallé State Historic Site, Ste.

Genevieve, Missouri.

2005 Exploring Assemblage Patterning in Ste. Genevieve, Missouri. Missouri

Archaeological Society Quarterly 22(1):10-21.

White, Carolyn L. and Mary C. Beaudry

2009 Artifacts and Personal Identity. In International Handbook of Historical

Archaeology, edited by Teresita Majewski and David Gaimster, pp. 209-225.

Springer Science and Business Media, LLC, New York.

White, Sophie

2012 Wild Frenchmen and Frenchified Indians: Material Culture and Race in Colonial Louisiana. University of Pennsylvania Press, Philadelphia.

Wilkie, Laurie A.

2000 Creating Freedom: Material Culture and African American Identity at Oakley

Plantation. Louisiana State University Press, Baton Rouge, Louisiana.

2001 Race, Identity, and Habermas's Lifeworld. In Race and the Archaeology of

Identity, edited by Charles Orser Jr., pp. 108-124. University of Utah Press.

Wolf, E. R.

1997 Europe and the People Without History. University of California Press, Berkeley. 
Wright, Rita P.

1996 Technology, Gender, and Class: Worlds of Difference in Ur III Mesopotamia. In Gender and Archaeology, edited by Rita P. Wright, pp. 79-110. University of Pennsylvania Press, Philadelphia.

Yentsch, Anne E.

1994 A Chesapeake Family and Their Slaves: A Study in Historical Archaeology. Cambridge University Press, Cambridge.

Young, Amy L.

1999 Archaeological Investigations of Slave Housing at Saragossa Plantation, Natchez, Mississippi. Southeastern Archaeology 18(1).

Zug, Charles G.

1986 Turners and Burners: The Folk Potters of North Carolina. University of North Carolina Press, Chapel Hill. 
APPENDIX

COMPREHENSIVE TABLES LISTING ARTIFACTS

A-1. Datable Artifacts from the Outbuilding during the Janis Occupation

\begin{tabular}{|c|c|c|c|c|c|c|c|}
\hline Material & $\begin{array}{l}\text { Artifact } \\
\text { Type }\end{array}$ & $\begin{array}{l}\text { Descriptio } \\
\mathrm{n}\end{array}$ & $\#$ & Unit & Level & Depth & $\begin{array}{l}\text { Range of } \\
\text { production }\end{array}$ \\
\hline Ceramic & $\begin{array}{l}\text { Creamwar } \\
\mathrm{e}\end{array}$ & Plain & & $\begin{array}{l}110 \mathrm{R} \\
0 \mathrm{Qu} . \\
1\end{array}$ & $\begin{array}{l}\text { Lv. } 7 \mathrm{~F} . \\
3\end{array}$ & $\begin{array}{l}1.05^{\prime}- \\
1.25^{\prime}\end{array}$ & $1762-1820$ \\
\hline Ceramic & $\begin{array}{l}\text { Refined } \\
\text { White } \\
\text { Earthenwa } \\
\text { re }\end{array}$ & $\begin{array}{l}\text { Shell- } \\
\text { edged }\end{array}$ & 1 & $\begin{array}{l}110 \mathrm{R} \\
0 \mathrm{Qu} . \\
1\end{array}$ & $\begin{array}{l}\text { Lv. } 7 \mathrm{~F} . \\
3\end{array}$ & $\begin{array}{l}1.05^{\prime}- \\
1.25^{\prime}\end{array}$ & $\begin{array}{l}1800- \\
1860+\end{array}$ \\
\hline Ceramic & $\begin{array}{l}\text { Refined } \\
\text { White } \\
\text { Earthenwa } \\
\text { re }\end{array}$ & $\begin{array}{l}\text { Plain, } \\
\text { burned }\end{array}$ & & $\begin{array}{l}110 \mathrm{R} \\
0 \mathrm{Qu} . \\
1\end{array}$ & $\begin{array}{l}\text { Lv. } 7 \mathrm{~F} . \\
3\end{array}$ & $1.05-1.25^{\prime}$ & $1780-1980$ \\
\hline Ceramic & $\begin{array}{l}\text { Refined } \\
\text { White } \\
\text { Earthenwa } \\
\text { re }\end{array}$ & $\begin{array}{l}\text { Clear } \\
\text { Brown } \\
\text { Glaze }\end{array}$ & & $\begin{array}{l}110 \mathrm{R} \\
0 \mathrm{Qu} . \\
1\end{array}$ & $\begin{array}{l}\text { Lv. } 7 \mathrm{~F} . \\
3\end{array}$ & $\begin{array}{l}1.05^{\prime}- \\
1.25^{\prime}\end{array}$ & $\begin{array}{l}1785- \\
1870+\end{array}$ \\
\hline Glass & $\begin{array}{l}\text { Vessel } \\
\text { Indetermin } \\
\text { ate }\end{array}$ & $\begin{array}{l}\text { Clear } \\
\text { Glass, } \\
\text { appears } \\
\text { "frosted" }\end{array}$ & & $\begin{array}{l}110 \mathrm{R} \\
0 \mathrm{Qu} . \\
1\end{array}$ & $\begin{array}{l}\text { Lv. } 7 \text { F. } \\
3\end{array}$ & $\begin{array}{l}1.05^{\prime}- \\
1.25^{\prime}\end{array}$ & $1875-1980$ \\
\hline Ceramic & $\begin{array}{l}\text { Refined } \\
\text { White } \\
\text { Earthenwa } \\
\text { re }\end{array}$ & Plain & & $\begin{array}{l}110 \mathrm{R} \\
0 \mathrm{Qu} . \\
1\end{array}$ & $\begin{array}{l}\text { LV. } 8 \mathrm{~F} . \\
3\end{array}$ & $\begin{array}{l}1.25^{\prime}- \\
1.45^{\prime}\end{array}$ & $1780-1980$ \\
\hline
\end{tabular}




\begin{tabular}{|c|c|c|c|c|c|c|}
\hline Glass & Vessel & $\begin{array}{l}\text { Olive } \\
\text { Green } \\
\text { Glass; } \\
\text { indetermi } \\
\text { nate form }\end{array}$ & $1 \begin{array}{l}110 \mathrm{R} \\
0 \mathrm{Qu} . \\
1\end{array}$ & $\begin{array}{l}\text { LV. } 8 \mathrm{~F} . \\
3\end{array}$ & $\begin{array}{l}1.25^{\prime}- \\
1.45^{\prime}\end{array}$ & $1792-1885$ \\
\hline Glass & Vessel & $\begin{array}{l}\text { Clear } \\
\text { Glass; } \\
\text { indetermi } \\
\text { nate form }\end{array}$ & $1 \begin{array}{l}\text { 110R } \\
0 \text { Qu. } \\
1\end{array}$ & $\begin{array}{l}\text { Lv. } 8 \mathrm{~F} . \\
3\end{array}$ & $\begin{array}{l}1.25^{\prime}- \\
1.45^{\prime}\end{array}$ & $1875-1980$ \\
\hline
\end{tabular}

(Source for Range of Production: Groover 2003)

A-2. Datable Artifacts from the Outbuilding during the Ziegler Occupation

\begin{tabular}{|c|c|c|c|c|c|c|c|}
\hline Material & $\begin{array}{l}\text { Artifact } \\
\text { Type }\end{array}$ & $\begin{array}{l}\text { Descripti } \\
\text { on }\end{array}$ & $\#$ & Unit & Level & Depth & $\begin{array}{l}\text { Range of } \\
\text { production }\end{array}$ \\
\hline Ceramic & $\begin{array}{l}\text { Whitewar } \\
\text { e }\end{array}$ & Plain & 1 & $\begin{array}{l}\text { 110R0 } \\
\text { Qu. } 1\end{array}$ & Lv. 5 F. 3 & $0.65^{\prime}-0.85^{\prime}$ & $1820-1980$ \\
\hline Ceramic & $\begin{array}{l}\text { Whitewar } \\
\text { e }\end{array}$ & $\begin{array}{l}\text { Plain; } \\
\text { Molded } \\
\text { Ridge } \\
\text { present }\end{array}$ & 1 & $\begin{array}{l}\text { 110R0 } \\
\text { Qu. } 1\end{array}$ & Lv. 5 F. 3 & $0.65^{\prime}-0.85^{\prime}$ & $\begin{array}{l}1830- \\
1860+\end{array}$ \\
\hline Ceramic & Pearlware & $\begin{array}{l}\text { Mocha: } \\
\text { Dark } \\
\text { Brown } \\
\text { Dendritic } \\
\text { Fern on a } \\
\text { Tan } \\
\text { Backgrou } \\
\text { nd }\end{array}$ & 1 & $\begin{array}{l}\text { 110R0 } \\
\text { Qu. } 1\end{array}$ & Lv. 5 F. 3 & $0.65^{\prime}-0.85^{\prime}$ & $1785-1890$ \\
\hline Ceramic & Pearlware & Plain & 1 & $\begin{array}{l}\text { 110R0 } \\
\text { Qu. } 1\end{array}$ & Lv. 5 F. 3 & $0.65^{\prime}-0.85^{\prime}$ & $1780-1830$ \\
\hline Ceramic & Pearlware & $\begin{array}{l}\text { Black } \\
\text { transfer } \\
\text { print or } \\
\text { maker's } \\
\text { mark }\end{array}$ & 1 & $\begin{array}{l}\text { 110R0 } \\
\text { Qu. } 1\end{array}$ & Lv. 5 F. 3 & $0.65^{\prime}-0.85^{\prime}$ & $1795-1820$ \\
\hline Ceramic & Pearlware & $\begin{array}{l}\text { Hand- } \\
\text { painted; } \\
\text { Floral } \\
\text { Design } \\
\text { (Green, }\end{array}$ & 1 & $\begin{array}{l}\text { 110R0 } \\
\text { Qu. } 1\end{array}$ & LV. 5 F. 3 & $0.65^{\prime}-0.85^{\prime}$ & $1780-1820$ \\
\hline
\end{tabular}




\begin{tabular}{|c|c|c|c|c|c|c|c|}
\hline Ceramic & Pearlware & $\begin{array}{l}\text { Annular } \\
\text { and Hand- } \\
\text { painted; } \\
\text { Interior } \\
\text { only } \\
\text { (yellow } \\
\text { and } \\
\text { brown } \\
\text { bands, } \\
\text { blue, } \\
\text { black/bro } \\
\text { wn and } \\
\text { green } \\
\text { floral } \\
\text { design }\end{array}$ & 1 & $\begin{array}{l}\text { 110R0 } \\
\text { Qu. } 1\end{array}$ & $\begin{array}{l}\text { Feature } \\
7\end{array}$ & $1.54^{\prime}-2.50^{\prime}$ & $1790-1820$ \\
\hline Ceramic & $\begin{array}{l}\text { Refined } \\
\text { White } \\
\text { Earthenw } \\
\text { are }\end{array}$ & $\begin{array}{l}\text { Burned; } \\
\text { possible } \\
\text { blue } \\
\text { decoratio } \\
\mathrm{n}\end{array}$ & 1 & $\begin{array}{l}\text { 110R0 } \\
\text { Qu. } 1\end{array}$ & $\begin{array}{l}\text { Feature } \\
7\end{array}$ & $1.54^{\prime}-2.50^{\prime}$ & $1795-1900$ \\
\hline Ceramic & $\begin{array}{l}\text { Creamwar } \\
\text { e }\end{array}$ & $\begin{array}{l}\text { Plain Salt } \\
\text { Glazed }\end{array}$ & 1 & $\begin{array}{l}\text { 110L1 } \\
0 \mathrm{Qu} . \\
2\end{array}$ & Lv. 9 & $1.05^{\prime}-1.15^{\prime}$ & $1762-1820$ \\
\hline Ceramic & $\begin{array}{l}\text { Creamwar } \\
\text { e }\end{array}$ & $\begin{array}{l}\text { Plain; Salt } \\
\text { Glazed } \\
\text { interior }\end{array}$ & 1 & $\begin{array}{l}\text { 110L1 } \\
0 \mathrm{Qu.} \\
2\end{array}$ & Lv. 9 & $1.05^{\prime}-1.15^{\prime}$ & $1762-1820$ \\
\hline Ceramic & $\begin{array}{l}\text { Creamwar } \\
\text { e }\end{array}$ & $\begin{array}{l}\text { Plain; Salt } \\
\text { Glazed } \\
\text { exterior }\end{array}$ & 1 & $\begin{array}{l}\text { 110L1 } \\
0 \mathrm{Qu.} \\
2\end{array}$ & Lv. 9 & $1.05^{\prime}-1.15^{\prime}$ & $1762-1820$ \\
\hline Ceramic & Pearlware & $\begin{array}{l}\text { Hand- } \\
\text { painted; } \\
\text { possible } \\
\text { annular } \\
\text { band and } \\
\text { floral } \\
\text { motif: } \\
\text { Dark } \\
\text { Brown, } \\
\text { light } \\
\text { Brown } \\
\text { and Green }\end{array}$ & 1 & $\begin{array}{l}110 \mathrm{L1} \\
0 \mathrm{Qu} . \\
2\end{array}$ & 更 & 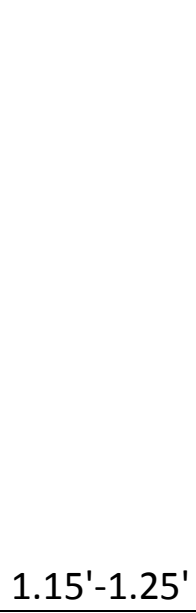 & $1790-1820$ \\
\hline Ceramic & Pearlware & Plain; thin & 1 & $\begin{array}{l}\text { 110L1 } \\
0 \mathrm{Qu.} . \\
2\end{array}$ & LV. 10 & $1.15^{\prime}-1.25^{\prime}$ & $1780-1830$ \\
\hline
\end{tabular}




\begin{tabular}{|c|c|c|c|c|c|c|c|}
\hline Ceramic & Pearlware & $\begin{array}{l}\text { Plain; thin } \\
\text { (thinner } \\
\text { than } \\
\text { above) }\end{array}$ & 1 & $\begin{array}{l}\text { 110L1 } \\
0 \mathrm{Qu} . \\
2\end{array}$ & Lv. 10 & $1.15^{\prime}-1.25^{\prime}$ & $1780-1830$ \\
\hline Glass & Bottle & $\begin{array}{l}\text { Aqua } \\
\text { Glass }\end{array}$ & 1 & \begin{tabular}{|l}
$110 \mathrm{~L} 1$ \\
$0 \mathrm{Qu}$. \\
2 \\
\end{tabular} & Lv. 11 & $1.25^{\prime}-1.35^{\prime}$ & $1800-1910$ \\
\hline Ceramic & $\begin{array}{l}\text { Refined } \\
\text { White } \\
\text { Earthenw } \\
\text { are }\end{array}$ & Plain & 1 & $\begin{array}{l}\text { 110L1 } \\
0 \mathrm{Qu} . \\
2\end{array}$ & Lv. $12 \mathrm{~A}$ & $1.35^{\prime}-1.40^{\prime}$ & $1780-1980$ \\
\hline Ceramic & Pearlware & $\begin{array}{l}\text { Annular } \\
\text { and Hand- } \\
\text { painted } \\
\text { (interior } \\
\text { only: } \\
\text { yellow } \\
\text { and } \\
\text { brown } \\
\text { bands; } \\
\text { blue, } \\
\text { black/bro } \\
\text { wn, yellow } \\
\text { and green } \\
\text { floral } \\
\text { design) }\end{array}$ & 3 & $\begin{array}{l}\text { 110L1 } \\
0 \mathrm{Qu} . \\
2\end{array}$ & $\begin{array}{l}\text { Feature } \\
7\end{array}$ & $\begin{array}{l}1 . .45^{\prime}- \\
1.55^{\prime}\end{array}$ & $1790-1820$ \\
\hline Ceramic & Pearlware & $\begin{array}{l}\text { Annular } \\
\text { and Hand- } \\
\text { painted; } \\
\text { interior } \\
\text { only } \\
\text { (yellow } \\
\text { and } \\
\text { brown } \\
\text { bands) }\end{array}$ & 1 & $\begin{array}{l}\text { 110L1 } \\
0 \mathrm{Qu} . \\
2\end{array}$ & $\begin{array}{l}\text { Feature } \\
7\end{array}$ & $1.56^{\prime}-2.67^{\prime}$ & $1790-1820$ \\
\hline Ceramic & Pearlware & $\begin{array}{l}\text { Blue shell- } \\
\text { edged; } \\
\text { Molded } \\
\text { and } \\
\text { painted }\end{array}$ & 1 & $\begin{array}{l}\text { 110L1 } \\
0 \mathrm{Qu} . \\
2\end{array}$ & $\begin{array}{l}\text { Feature } \\
7\end{array}$ & $1.56^{\prime}-2.67^{\prime}$ & $1790-1820$ \\
\hline Ceramic & $\begin{array}{l}\text { Refined } \\
\text { White }\end{array}$ & Plain & 1 & $\begin{array}{l}\text { 110L1 } \\
0 \mathrm{Qu} . \\
2\end{array}$ & $\begin{array}{l}\text { Feature } \\
7\end{array}$ & $1.56^{\prime}-2.67^{\prime}$ & $1780-1980$ \\
\hline
\end{tabular}




\begin{tabular}{|c|c|c|c|c|c|c|c|}
\hline & $\begin{array}{l}\text { Earthenw } \\
\text { are }\end{array}$ & & & & & & \\
\hline & & $\begin{array}{l}\text { Brown, } \\
\text { Blue, } \\
\text { Yellow) }\end{array}$ & & & & & \\
\hline Ceramic & $\begin{array}{l}\text { Refined } \\
\text { White } \\
\text { Earthenwa } \\
\text { re }\end{array}$ & $\begin{array}{l}\text { Hand- } \\
\text { painted } \\
\text { lines; } \\
\text { burned; } \\
\text { Some } \\
\text { Crazing; } \\
\text { Cut } \\
\text { Marks; } \\
\text { Black } \\
\text { lines } \\
\end{array}$ & 1 & $\begin{array}{l}\text { 110R0 } \\
\text { Qu. } 1\end{array}$ & Lv. 5 F. 3 & $0.65^{\prime}-0.85^{\prime}$ & $1795-1900$ \\
\hline Glass & $\begin{array}{l}\text { Pharmace } \\
\text { utical } \\
\text { Bottle }\end{array}$ & $\begin{array}{l}\text { Aqua } \\
\text { colored } \\
\text { glass }\end{array}$ & 1 & $\begin{array}{l}\text { 110R0 } \\
\text { Qu. } 1\end{array}$ & Lv. 5 F. 3 & $0.65^{\prime}-0.85^{\prime}$ & $1800-1910$ \\
\hline Glass & $\begin{array}{l}\text { Vessel } \\
\text { Indetermi } \\
\text { nate }\end{array}$ & $\begin{array}{l}\text { Olive } \\
\text { Green } \\
\text { Glass } \\
\end{array}$ & 1 & $\begin{array}{l}\text { 110R0 } \\
\text { Qu. } 1\end{array}$ & Lv. 5 F. 3 & $0.65^{\prime}-0.85^{\prime}$ & $1792-1885$ \\
\hline Ceramic & Pearlware & $\begin{array}{l}\text { Green } \\
\text { shell- } \\
\text { edged } \\
\text { scalloped } \\
\text { rim }\end{array}$ & 1 & $\begin{array}{l}\text { 110R0 } \\
\text { Qu. } 1\end{array}$ & Lv. 6 F. 3 & $0.85^{\prime}-1.05^{\prime}$ & $1800-1820$ \\
\hline Ceramic & $\begin{array}{l}\text { Refined } \\
\text { White } \\
\text { Earthenwa } \\
\text { re }\end{array}$ & $\begin{array}{l}\text { Glaze } \\
\text { seemed } \\
\text { to have } \\
\text { some } \\
\text { blue in it; } \\
\text { burned }\end{array}$ & 1 & $\begin{array}{l}\text { 110R0 } \\
\text { Qu. } 1\end{array}$ & Lv. 6 F. 3 & $0.85^{\prime}-1.05^{\prime}$ & $1795-1900$ \\
\hline Ceramic & $\begin{array}{l}\text { Whitewar } \\
\text { e }\end{array}$ & Plain & 1 & $\begin{array}{l}\text { 110R0 } \\
\text { Qu. } 3\end{array}$ & Lv. 6 F. 5 & $0.85^{\prime}-1.05^{\prime}$ & $1820-1980$ \\
\hline Ceramic & Pearlware & Plain & 1 & $\begin{array}{l}\text { 110R0 } \\
\text { Qu. } 3\end{array}$ & LV. 6 F. 3 & $0.85^{\prime}-1.05^{\prime}$ & $1780-1830$ \\
\hline Ceramic & $\begin{array}{l}\text { Yellowwar } \\
\text { e }\end{array}$ & Plain & 1 & $\begin{array}{l}\text { 110L1 } \\
0 \mathrm{Qu} . \\
2\end{array}$ & Lv. 5 & $0.65^{\prime}-0.75^{\prime}$ & $1830-1930$ \\
\hline Ceramic & $\begin{array}{l}\text { Whitewar } \\
\text { e }\end{array}$ & Flow-Blue & 1 & $\begin{array}{l}\text { 110L1 } \\
0 \mathrm{Qu} . \\
2\end{array}$ & Lv. 5 & $0.65^{\prime}-0.75^{\prime}$ & $1840-1900$ \\
\hline
\end{tabular}




\begin{tabular}{|c|c|c|c|c|c|c|c|}
\hline Ceramic & $\begin{array}{l}\text { Whitewar } \\
\text { e }\end{array}$ & $\begin{array}{l}\text { Hand- } \\
\text { painted; } \\
\text { Partial } \\
\text { Blue } \\
\text { Design } \\
\end{array}$ & 1 & $\begin{array}{l}\text { 110L1 } \\
0 \mathrm{Qu} . \\
2\end{array}$ & Lv. 5 & $0.65^{\prime}-0.75^{\prime}$ & $1830-1900$ \\
\hline Ceramic & $\begin{array}{l}\text { Whitewar } \\
\text { e }\end{array}$ & $\begin{array}{l}\text { Camel- } \\
\text { colored } \\
\text { glaze; } \\
\text { Possibly } \\
\text { Mocha }\end{array}$ & 1 & $\begin{array}{l}110 \mathrm{~L} 1 \\
0 \mathrm{Qu} . \\
2\end{array}$ & Lv. 5 & $0.65^{\prime}-0.75^{\prime}$ & $\begin{array}{l}1830- \\
1870+\end{array}$ \\
\hline Ceramic & $\begin{array}{l}\text { Creamwar } \\
\mathrm{e}\end{array}$ & Plain & 1 & $\begin{array}{l}\text { 110L1 } \\
0 \mathrm{Qu} . \\
2\end{array}$ & Lv. 5 & $0.65^{\prime}-0.75^{\prime}$ & $1762-1820$ \\
\hline Ceramic & $\begin{array}{l}\text { Creamwar } \\
\text { e }\end{array}$ & Plain & 2 & $\begin{array}{l}\text { 110L1 } \\
0 \mathrm{Qu} . \\
2\end{array}$ & Lv. 5 & $0.65^{\prime}-0.75^{\prime}$ & $1762-1820$ \\
\hline Ceramic & $\begin{array}{l}\text { Whitewar } \\
\text { e }\end{array}$ & Plain & 2 & $\begin{array}{l}\text { 110L1 } \\
0 \text { Qu. } \\
2\end{array}$ & Lv. 5 & $0.65^{\prime}-0.75^{\prime}$ & $1820-1980$ \\
\hline Ceramic & $\begin{array}{l}\text { Refined } \\
\text { White } \\
\text { Earthenwa } \\
\text { re }\end{array}$ & $\begin{array}{l}\text { Glaze } \\
\text { missing } \\
\text { or } \\
\text { exfoliated }\end{array}$ & 3 & $\begin{array}{l}\text { 110L1 } \\
0 \mathrm{Qu} . \\
2\end{array}$ & Lv. 5 & $0.65^{\prime}-0.75^{\prime}$ & $1780-1980$ \\
\hline Glass & $\begin{array}{l}\text { Pharmace } \\
\text { utical } \\
\text { Bottle }\end{array}$ & $\begin{array}{l}\text { Clear } \\
\text { Glass, } \\
\text { Appears } \\
\text { "frosted" } \\
\end{array}$ & 1 & $\begin{array}{l}\text { 110L1 } \\
0 \mathrm{Qu} . \\
2\end{array}$ & Lv. 5 & $0.65^{\prime}-0.75^{\prime}$ & $1875-1980$ \\
\hline Glass & $\begin{array}{l}\text { Small } \\
\text { Bottle }\end{array}$ & $\begin{array}{l}\text { Aqua } \\
\text { colored } \\
\text { glass } \\
\end{array}$ & 1 & \begin{tabular}{|l}
$110 \mathrm{~L} 1$ \\
$0 \mathrm{Qu}$. \\
2
\end{tabular} & Lv. 5 & $0.65^{\prime}-0.75^{\prime}$ & $1800-1910$ \\
\hline Glass & $\begin{array}{l}\text { Vessel } \\
\text { Indetermi } \\
\text { nate }\end{array}$ & $\begin{array}{l}\text { Clear } \\
\text { Glass }\end{array}$ & 1 & $\begin{array}{l}110 \mathrm{~L} 1 \\
0 \mathrm{Qu} . \\
2\end{array}$ & Lv. 5 & $0.65^{\prime}-0.75^{\prime}$ & $1875-1980$ \\
\hline Ceramic & $\begin{array}{l}\text { Whitewar } \\
\text { e }\end{array}$ & $\begin{array}{l}\text { Plain; } \\
\text { Dark } \\
\text { Staining }\end{array}$ & 1 & $\begin{array}{l}\text { 110L1 } \\
0 \mathrm{Qu} . \\
2\end{array}$ & Lv. 6 & $0.75^{\prime}-0.85^{\prime}$ & $1820-1980$ \\
\hline Ceramic & $\begin{array}{l}\text { Whitewar } \\
\text { e/Ironston } \\
\text { e }\end{array}$ & Plain & 5 & $\begin{array}{l}110 \mathrm{~L} 1 \\
0 \mathrm{Qu} . \\
2\end{array}$ & Lv. 6 & $0.75^{\prime}-0.85^{\prime}$ & $1820-1980$ \\
\hline Ceramic & $\begin{array}{l}\text { Yellowwar } \\
\text { e }\end{array}$ & Plain & 1 & $\begin{array}{l}\text { 110L1 } \\
0 \mathrm{Qu} . \\
2\end{array}$ & LV. 6 & $0.75^{\prime}-0.85^{\prime}$ & $1830-1930$ \\
\hline
\end{tabular}




\begin{tabular}{|c|c|c|c|c|c|c|c|}
\hline Ceramic & Pearlware & \begin{tabular}{|l} 
Hand- \\
painted \\
(Yellow, \\
Brown, \\
Blue) \\
\end{tabular} & 1 & $\begin{array}{l}\text { 110L1 } \\
0 \text { Qu. } \\
2\end{array}$ & Lv. 6 & $0.75^{\prime}-0.85^{\prime}$ & $1780-1820$ \\
\hline Ceramic & Pearlware & $\begin{array}{l}\text { Hand- } \\
\text { painted; } \\
\text { Floral } \\
\text { Design } \\
\text { (Green } \\
\text { and } \\
\text { Brown) } \\
\end{array}$ & 1 & $\begin{array}{l}\text { 110L1 } \\
0 \text { Qu. } \\
2\end{array}$ & Lv. 6 & $0.75^{\prime}-0.85^{\prime}$ & $1780-1820$ \\
\hline Ceramic & Pearlware & \begin{tabular}{|l} 
Green \\
Shell- \\
edge
\end{tabular} & 1 & \begin{tabular}{|l}
$110 \mathrm{~L} 1$ \\
$0 \mathrm{Qu}$. \\
2
\end{tabular} & Lv. 6 & $0.75^{\prime}-0.85^{\prime}$ & $1800-1820$ \\
\hline Ceramic & Pearlware & $\begin{array}{l}\text { Annular } \\
\text { design; } \\
\text { Thin } \\
\text { annular } \\
\text { band } \\
\text { (Light } \\
\text { Brown) }\end{array}$ & 1 & $\begin{array}{l}\text { 110L1 } \\
0 \text { Qu. } \\
2\end{array}$ & Lv. 6 & $0.75^{\prime}-0.85^{\prime}$ & $1790-1820$ \\
\hline Ceramic & $\begin{array}{l}\text { Creamwar } \\
\mathrm{e}\end{array}$ & Plain & 1 & $\begin{array}{l}\text { 110L1 } \\
0 \text { Qu. } \\
2\end{array}$ & Lv. 6 & $0.75^{\prime}-0.85^{\prime}$ & $1762-1820$ \\
\hline Ceramic & $\begin{array}{l}\text { Creamwar } \\
\mathrm{e}\end{array}$ & Plain & 7 & $\begin{array}{l}110 \mathrm{~L} 1 \\
0 \mathrm{Qu} . \\
2\end{array}$ & Lv. 6 & $0.75^{\prime}-0.85^{\prime}$ & $1762-1820$ \\
\hline Ceramic & $\begin{array}{l}\text { Creamwar } \\
\mathrm{e}\end{array}$ & $\begin{array}{l}\text { Plain; } \\
\text { glaze } \\
\text { chips }\end{array}$ & 2 & $\begin{array}{l}\text { 110L1 } \\
0 \mathrm{Qu} . \\
2\end{array}$ & Lv. 6 & $0.75^{\prime}-0.85^{\prime}$ & $1762-1820$ \\
\hline Ceramic & $\begin{array}{l}\text { Refined } \\
\text { White } \\
\text { Earthenwa } \\
\text { re }\end{array}$ & $\begin{array}{l}\text { Molded } \\
\text { Blue } \\
\text { shell- } \\
\text { edge }\end{array}$ & 1 & $\begin{array}{l}\text { 110L1 } \\
0 \mathrm{Qu} . \\
2\end{array}$ & Lv. 6 & $0.75^{\prime}-0.85^{\prime}$ & $\begin{array}{l}1800- \\
1860+\end{array}$ \\
\hline Ceramic & $\begin{array}{l}\text { Refined } \\
\text { White } \\
\text { Earthenwa } \\
\text { re }\end{array}$ & \begin{tabular}{|l} 
Hand- \\
painted \\
(Red/Pink \\
) \\
\end{tabular} & 1 & $\begin{array}{l}\text { 110L1 } \\
0 \text { Qu. } \\
2\end{array}$ & Lv. 6 & $0.75^{\prime}-0.85^{\prime}$ & $1780-1900$ \\
\hline Ceramic & $\begin{array}{l}\text { Refined } \\
\text { White } \\
\text { Earthenwa } \\
\text { re }\end{array}$ & Plain & 6 & $\begin{array}{l}\text { 110L1 } \\
0 \text { Qu. } \\
2\end{array}$ & Lv. 6 & $0.75^{\prime}-0.85^{\prime}$ & $1780-1980$ \\
\hline
\end{tabular}




\begin{tabular}{|c|c|c|c|c|c|c|c|}
\hline Glass & $\begin{array}{l}\text { Vessel } \\
\text { Indetermi } \\
\text { nate }\end{array}$ & $\begin{array}{l}\text { Olive } \\
\text { Green } \\
\text { Glass }\end{array}$ & 1 & $\begin{array}{l}\text { 110L1 } \\
0 \mathrm{Qu} . \\
2\end{array}$ & Lv. 6 & $0.75^{\prime}-0.85^{\prime}$ & $1792-1885$ \\
\hline Glass & $\begin{array}{l}\text { Vessel } \\
\text { Indetermi } \\
\text { nate }\end{array}$ & \begin{tabular}{|l} 
Aqua \\
colored \\
glass; \\
indetermi \\
nate; \\
Possibly \\
Pharmace \\
utical \\
bottle, \\
appears \\
"frosted" \\
\end{tabular} & 1 & $\begin{array}{l}\text { 110L1 } \\
0 \mathrm{Qu} . \\
2\end{array}$ & Lv. 6 & $0.75^{\prime}-0.85^{\prime}$ & $1800-1910$ \\
\hline Glass & Vessel & $\begin{array}{l}\text { Clear } \\
\text { Glass; } \\
\text { indetermi } \\
\text { nate } \\
\end{array}$ & 1 & $\begin{array}{l}\text { 110L1 } \\
0 \mathrm{Qu} . \\
2\end{array}$ & Lv. 6 & $0.75^{\prime}-0.85^{\prime}$ & $1875-1980$ \\
\hline Ceramic & $\begin{array}{l}\text { Whitewar } \\
\text { e }\end{array}$ & $\begin{array}{l}\text { Embosse } \\
d \text {, color- } \\
\text { less shell- } \\
\text { edged }\end{array}$ & 1 & $\begin{array}{l}\text { 110L1 } \\
0 \mathrm{Qu} . \\
2 \\
\end{array}$ & Lv. 7 & $0.85^{\prime}-0.95^{\prime}$ & $\begin{array}{l}1830- \\
1860+ \\
\end{array}$ \\
\hline Ceramic & $\begin{array}{l}\text { Whitewar } \\
\text { e }\end{array}$ & $\begin{array}{l}\text { Transfer } \\
\text { print } \\
\text { (red) }\end{array}$ & 1 & $\begin{array}{l}110 \mathrm{~L} 1 \\
0 \mathrm{Qu} . \\
2\end{array}$ & Lv. 7 & $0.85^{\prime}-0.95^{\prime}$ & $1828-1850$ \\
\hline Ceramic & $\begin{array}{l}\text { Whitewar } \\
\text { e }\end{array}$ & $\begin{array}{l}\text { Green } \\
\text { Shell- } \\
\text { edged; } \\
\text { burned }\end{array}$ & 1 & $\begin{array}{l}\text { 110L1 } \\
0 \mathrm{Qu} . \\
2\end{array}$ & Lv. 7 & $0.85^{\prime}-0.95^{\prime}$ & $\begin{array}{l}1830- \\
1860+ \\
\end{array}$ \\
\hline Ceramic & $\begin{array}{l}\text { Refined } \\
\text { White } \\
\text { Earthenwa } \\
\text { re }\end{array}$ & Plain & 3 & $\begin{array}{l}\text { 110L1 } \\
0 \mathrm{Qu} . \\
2\end{array}$ & Lv. 7 & $0.85^{\prime}-0.95^{\prime}$ & $1780-1980$ \\
\hline Ceramic & $\begin{array}{l}\text { Whitewar } \\
\text { e }\end{array}$ & \begin{tabular}{|l|} 
Transfer \\
print; \\
Floral \\
(Dark \\
Purple) \\
\end{tabular} & 1 & $\begin{array}{l}\text { 110L1 } \\
0 \mathrm{Qu} . \\
2\end{array}$ & Lv. 8 & $0.95^{\prime}-1.05^{\prime}$ & $1865-1915$ \\
\hline Ceramic & $\begin{array}{l}\text { Whitewar } \\
\text { e }\end{array}$ & Plain & 1 & $\begin{array}{l}\text { 110L1 } \\
0 \mathrm{Qu} . \\
2\end{array}$ & Lv. 8 & $0.95^{\prime}-1.05^{\prime}$ & $1820-1980$ \\
\hline
\end{tabular}




\begin{tabular}{|c|c|c|c|c|c|c|c|}
\hline Ceramic & $\begin{array}{l}\text { Whitewar } \\
\text { e }\end{array}$ & Plain & 1 & $\begin{array}{l}\text { 110L1 } \\
0 \mathrm{Qu} . \\
2\end{array}$ & Lv. 8 & $0.95^{\prime}-1.05^{\prime}$ & $1820-1980$ \\
\hline Ceramic & $\begin{array}{l}\text { Creamwar } \\
\text { e }\end{array}$ & Plain & 1 & $\begin{array}{l}\text { 110L1 } \\
0 \mathrm{Qu} . \\
2\end{array}$ & Lv. 8 & $0.95^{\prime}-1.05^{\prime}$ & $1762-1820$ \\
\hline Glass & $\begin{array}{l}\text { Panel } \\
\text { Bottle }\end{array}$ & $\begin{array}{l}\text { Aqua } \\
\text { colored } \\
\text { glass }\end{array}$ & 1 & $\begin{array}{l}\text { 110L1 } \\
0 \text { Qu. } \\
2\end{array}$ & LV. 8 & $0.95^{\prime}-1.05^{\prime}$ & $1800-1910$ \\
\hline
\end{tabular}

(Source for Range of Production: Groover 2003)

A-3. Functional List for the Outbuilding during the Janis Occupation

\begin{tabular}{|c|c|c|c|c|c|c|}
\hline Type & Artifact & $\begin{array}{l}\text { Functional } \\
\text { Categories }\end{array}$ & MNV & $\#$ & $\begin{array}{l}\text { Total per } \\
\text { category }\end{array}$ & $\%$ of whole \\
\hline Creamware & $\begin{array}{l}\text { Medium- } \\
\text { Large Bowl }\end{array}$ & $\begin{array}{l}\text { Food Serving } \\
\text { and } \\
\text { Consumption }\end{array}$ & 1 & 3 & & \\
\hline Creamware & Plate/Bowl & $\begin{array}{l}\text { Food Serving } \\
\text { and } \\
\text { Consumption }\end{array}$ & 1 & 1 & & \\
\hline $\begin{array}{l}\text { Refined } \\
\text { White } \\
\text { Earthenware }\end{array}$ & $\begin{array}{l}\text { Plate/Shallo } \\
\text { w Bowl }\end{array}$ & $\begin{array}{l}\text { Food Serving } \\
\text { and } \\
\text { Consumption }\end{array}$ & 1 & 1 & & \\
\hline $\begin{array}{l}\text { Refined } \\
\text { White } \\
\text { Earthenware }\end{array}$ & $\begin{array}{l}\text { Plate/Platte } \\
r\end{array}$ & $\begin{array}{l}\text { Food Serving } \\
\text { and } \\
\text { Consumption }\end{array}$ & 1 & 1 & & \\
\hline Pearlware & $\begin{array}{l}\text { Medium } \\
\text { Bowl }\end{array}$ & $\begin{array}{l}\text { Food Serving } \\
\text { and } \\
\text { Consumption }\end{array}$ & 1 & 1 & 7 & $0.8 \%$ \\
\hline $\begin{array}{l}\text { Coarse Red } \\
\text { Earthenware }\end{array}$ & Large Bowl & $\begin{array}{l}\text { Food } \\
\text { Preparation }\end{array}$ & 1 & 1 & 1 & $0.1 \%$ \\
\hline Glass & Vessel Glass & Food Storage & & 4 & 4 & $0.5 \%$ \\
\hline Metal & $\begin{array}{l}\text { Curtain } \\
\text { Hook }\end{array}$ & $\begin{array}{l}\text { Interior } \\
\text { Design and } \\
\text { Decoration }\end{array}$ & & 1 & 1 & $0.1 \%$ \\
\hline Metal & Straight Pin & Sewing & & 1 & 1 & $0.1 \%$ \\
\hline Architectural & Brick & $\begin{array}{l}\text { Construction } \\
\text { and } \\
\text { Maintenance }\end{array}$ & & 107 & & \\
\hline
\end{tabular}




\begin{tabular}{|c|c|c|c|c|c|}
\hline Architectural & $\begin{array}{l}\text { Lime } \\
\text { Mortar/Plas } \\
\text { ter }\end{array}$ & $\begin{array}{l}\text { Construction } \\
\text { and } \\
\text { Maintenance }\end{array}$ & 237 & & \\
\hline Architectural & $\begin{array}{l}\text { Window } \\
\text { Glass }\end{array}$ & $\begin{array}{l}\text { Construction } \\
\text { and } \\
\text { Maintenance }\end{array}$ & 4 & & \\
\hline Architectural & Cut Nail & $\begin{array}{l}\text { Construction } \\
\text { and } \\
\text { Maintenance }\end{array}$ & 11 & & \\
\hline Architectural & Bousillage & $\begin{array}{l}\text { Construction } \\
\text { and } \\
\text { Maintenance }\end{array}$ & 5 & 364 & $41.4 \%$ \\
\hline Bone & Bone & Food Remains & 117 & & \\
\hline Shell & Shell & Food Remains & 65 & & \\
\hline Eggshell & Eggshell & Food Remains & 131 & & \\
\hline $\begin{array}{l}\text { Plant } \\
\text { Remains }\end{array}$ & Plant & Food Remains & 82 & & \\
\hline $\begin{array}{l}\text { Unidentified } \\
\text { Food }\end{array}$ & Unidentified & Food Remains & 3 & 398 & $45.3 \%$ \\
\hline Gun Parts & Gun flint & $\begin{array}{l}\text { Hunting/Wea } \\
\text { ponry }\end{array}$ & 1 & 1 & $0.1 \%$ \\
\hline Gun Parts & Lead Trailer & $\begin{array}{l}\text { Lead Shot } \\
\text { Production }\end{array}$ & 1 & 1 & $0.1 \%$ \\
\hline Gastrolith & Gastrolith & $\begin{array}{l}\text { Domestic } \\
\text { Fowl } \\
\text { Production }\end{array}$ & 4 & 4 & $0.5 \%$ \\
\hline Stone & Catlinite & Trade & 1 & 1 & $0.1 \%$ \\
\hline Whetstone & Whetstone & Tool & 1 & & \\
\hline Metal & Wire & Tool & 1 & 2 & $0.2 \%$ \\
\hline Sheet Metal & Unidentified & Unidentified & 2 & & \\
\hline Metal & Unidentified & Unidentified & 86 & & \\
\hline Pearlware & Unidentified & Unidentified & 1 & & \\
\hline Pearlware & Unidentified & Unidentified & 1 & & \\
\hline
\end{tabular}




\begin{tabular}{|c|c|c|c|c|c|}
\hline $\begin{array}{l}\text { Refined } \\
\text { White } \\
\text { Earthenware }\end{array}$ & Unidentified & Unidentified & 1 & & \\
\hline $\begin{array}{l}\text { Coarse Red } \\
\text { Earthenware }\end{array}$ & Unidentified & Unidentified & 1 & & \\
\hline $\begin{array}{l}\text { Coarse Red } \\
\text { Earthenware }\end{array}$ & Unidentified & Unidentified & 1 & & \\
\hline $\begin{array}{l}\text { Coarse Red } \\
\text { Earthenware }\end{array}$ & Unidentified & Unidentified & 1 & 94 & $10.7 \%$ \\
\hline Total(s) & & & 879 & 879 & $100.0 \%$ \\
\hline
\end{tabular}

A-4. Functional List for the Outbuilding during the Ziegler Occupation

\begin{tabular}{|c|c|c|c|c|c|c|}
\hline Type & Artifact & $\begin{array}{l}\text { Functional } \\
\text { Categories }\end{array}$ & MNV & \# & $\begin{array}{l}\text { Total per } \\
\text { category }\end{array}$ & $\%$ of whole \\
\hline Pearlware & $\begin{array}{l}\text { Small- } \\
\text { Medium } \\
\text { Straight } \\
\text { Sided Bowl }\end{array}$ & $\begin{array}{l}\text { Food Serving } \\
\text { and } \\
\text { Consumption }\end{array}$ & 1 & 1 & & \\
\hline Creamware & $\begin{array}{l}\text { Plate/Platt } \\
\text { er } \\
\text { (possibly) }\end{array}$ & $\begin{array}{l}\text { Food Serving } \\
\text { and } \\
\text { Consumption }\end{array}$ & 1 & 1 & & \\
\hline Pearlware & $\begin{array}{l}\text { Small Bowl } \\
\text { (possibly) }\end{array}$ & $\begin{array}{l}\text { Food Serving } \\
\text { and } \\
\text { Consumption } \\
\end{array}$ & 1 & 1 & & \\
\hline Whiteware & $\begin{array}{l}\text { Plate/Sauc } \\
\text { er }\end{array}$ & $\begin{array}{l}\text { Food Serving } \\
\text { and } \\
\text { Consumption }\end{array}$ & 1 & 2 & & \\
\hline Whiteware & Plate & $\begin{array}{l}\text { Food Serving } \\
\text { and } \\
\text { Consumption }\end{array}$ & 1 & 1 & & \\
\hline Whiteware & $\begin{array}{l}\text { Plate/Sauc } \\
\text { er }\end{array}$ & $\begin{array}{l}\text { Food Serving } \\
\text { and } \\
\text { Consumption }\end{array}$ & 1 & 1 & & \\
\hline Pearlware & $\begin{array}{l}\text { Medium } \\
\text { Bowl }\end{array}$ & $\begin{array}{l}\text { Food Serving } \\
\text { and } \\
\text { Consumption }\end{array}$ & 1 & 2 & & \\
\hline Whiteware & $\begin{array}{l}\text { Medium } \\
\text { Hollowwar } \\
\text { e }\end{array}$ & $\begin{array}{l}\text { Food Serving } \\
\text { and } \\
\text { Consumption }\end{array}$ & 1 & 1 & & \\
\hline
\end{tabular}




\begin{tabular}{|c|c|c|c|c|c|c|}
\hline Whiteware & $\begin{array}{l}\text { Medium- } \\
\text { Large Bowl }\end{array}$ & $\begin{array}{l}\text { Food Serving } \\
\text { and } \\
\text { Consumption }\end{array}$ & 1 & 1 & & \\
\hline Whiteware & $\begin{array}{l}\text { Medium- } \\
\text { Large Bowl }\end{array}$ & $\begin{array}{l}\text { Food Serving } \\
\text { and } \\
\text { Consumption }\end{array}$ & 1 & 1 & & \\
\hline $\begin{array}{l}\text { Coarse Red } \\
\text { Earthenware }\end{array}$ & $\begin{array}{l}\text { Medium } \\
\text { Vessel }\end{array}$ & $\begin{array}{l}\text { Food Serving } \\
\text { and } \\
\text { Consumption }\end{array}$ & 1 & 1 & & \\
\hline $\begin{array}{l}\text { Whiteware/Ir } \\
\text { onstone }\end{array}$ & Plate & $\begin{array}{l}\text { Food Serving } \\
\text { and } \\
\text { Consumption }\end{array}$ & 1 & 5 & & \\
\hline Creamware & $\begin{array}{l}\text { Large } \\
\text { Bowl/Plate }\end{array}$ & $\begin{array}{l}\text { Food Serving } \\
\text { and } \\
\text { Consumption }\end{array}$ & 1 & 7 & & \\
\hline $\begin{array}{l}\text { Coarse Red } \\
\text { Earthenware }\end{array}$ & $\begin{array}{l}\text { Medium } \\
\text { Vessel }\end{array}$ & $\begin{array}{l}\text { Food Serving } \\
\text { and } \\
\text { Consumption }\end{array}$ & 1 & 2 & & \\
\hline $\begin{array}{l}\text { Coarse Red } \\
\text { Earthenware }\end{array}$ & $\begin{array}{l}\text { Medium- } \\
\text { Large } \\
\text { Vessel }\end{array}$ & $\begin{array}{l}\text { Food Serving } \\
\text { and } \\
\text { Consumption }\end{array}$ & 1 & 1 & & \\
\hline Pearlware & $\begin{array}{l}\text { Cup or } \\
\text { Small Bowl }\end{array}$ & $\begin{array}{l}\text { Food Serving } \\
\text { and } \\
\text { Consumption }\end{array}$ & 1 & 1 & & \\
\hline Stoneware & $\begin{array}{l}\text { Hollowwar } \\
\text { e }\end{array}$ & $\begin{array}{l}\text { Food Serving } \\
\text { and } \\
\text { Consumption }\end{array}$ & 1 & 1 & & \\
\hline Whiteware & Bowl & $\begin{array}{l}\text { Food Serving } \\
\text { and } \\
\text { Consumption }\end{array}$ & 1 & 1 & 31 & $2.9 \%$ \\
\hline $\begin{array}{l}\text { Coarse Red } \\
\text { Earthenware }\end{array}$ & $\begin{array}{l}\text { Large } \\
\text { Ovoid } \\
\text { Crock or } \\
\text { Butter Jar }\end{array}$ & Food Storage & 1 & 1 & & \\
\hline $\begin{array}{l}\text { Coarse Red } \\
\text { Earthenware }\end{array}$ & $\begin{array}{l}\text { Large } \\
\text { Hollowwar } \\
\text { e }\end{array}$ & Food Storage & 1 & 2 & & \\
\hline Metal & Barrel Band & Food Storage & & 3 & & \\
\hline Glass & \begin{tabular}{|l|} 
Vessel \\
Glass \\
\end{tabular} & Food Storage & & 11 & 17 & $1.6 \%$ \\
\hline Yellowware & $\begin{array}{l}\text { Large } \\
\text { Bowl/Cham } \\
\text { ber pot }\end{array}$ & $\begin{array}{l}\text { Health/Sanitat } \\
\text { ion }\end{array}$ & 1 & 2 & & \\
\hline
\end{tabular}




\begin{tabular}{|c|c|c|c|c|c|c|}
\hline Glass & $\begin{array}{l}\text { Pharmaceu } \\
\text { tical Bottle }\end{array}$ & $\begin{array}{l}\text { Health/Sanitat } \\
\text { ion }\end{array}$ & 3 & 3 & 5 & $0.5 \%$ \\
\hline Metal & Screw & $\begin{array}{l}\text { Interior } \\
\text { Design and } \\
\text { Decoration }\end{array}$ & & 1 & 1 & $0.1 \%$ \\
\hline Metal & $\begin{array}{l}\text { Brass Shoe } \\
\text { Eyelet }\end{array}$ & $\begin{array}{l}\text { Worn, } \\
\text { repaired or } \\
\text { lost clothing } \\
\text { articles } \\
\end{array}$ & & 1 & & \\
\hline Metal & $\begin{array}{l}\text { Hook (hook } \\
\text { and eye) }\end{array}$ & $\begin{array}{l}\text { Worn, } \\
\text { repaired or } \\
\text { lost clothing } \\
\text { articles } \\
\end{array}$ & & 1 & & \\
\hline Metal & $\begin{array}{l}\text { Brass } \\
\text { Button }\end{array}$ & $\begin{array}{l}\text { Worn, } \\
\text { repaired or } \\
\text { lost clothing } \\
\text { articles } \\
\end{array}$ & & 1 & & \\
\hline Metal & Snap & $\begin{array}{l}\text { Worn, } \\
\text { repaired or } \\
\text { lost clothing } \\
\text { articles } \\
\end{array}$ & & 2 & 5 & $0.5 \%$ \\
\hline Metal & Knife & Tool & & 3 & & \\
\hline Metal & Wire & Tool & & 1 & 4 & $0.4 \%$ \\
\hline Metal & $\begin{array}{l}\text { L-Shaped } \\
\text { Nail }\end{array}$ & $\begin{array}{l}\text { Animal } \\
\text { Shoeing }\end{array}$ & & 1 & 1 & $0.1 \%$ \\
\hline Construction & Brick & $\begin{array}{l}\text { Construction } \\
\text { and } \\
\text { Maintenance }\end{array}$ & & 143 & & \\
\hline Construction & $\begin{array}{l}\text { Lime } \\
\text { Mortar/Pla } \\
\text { ster }\end{array}$ & $\begin{array}{l}\text { Construction } \\
\text { and } \\
\text { Maintenance }\end{array}$ & & 125 & & \\
\hline Construction & Slate & $\begin{array}{l}\text { Construction } \\
\text { and } \\
\text { Maintenance }\end{array}$ & & 3 & & \\
\hline Metal & Cut Nail & $\begin{array}{l}\text { Construction } \\
\text { and } \\
\text { Maintenance } \\
\end{array}$ & & 85 & & \\
\hline Flat Glass & $\begin{array}{l}\text { Window } \\
\text { Glass }\end{array}$ & $\begin{array}{l}\text { Construction } \\
\text { and } \\
\text { Maintenance } \\
\end{array}$ & & 11 & & \\
\hline Construction & $\begin{array}{l}\text { Wire Nail } \\
\text { (possibly) }\end{array}$ & $\begin{array}{l}\text { Construction } \\
\text { and } \\
\text { Maintenance } \\
\end{array}$ & & 4 & & \\
\hline
\end{tabular}




\begin{tabular}{|c|c|c|c|c|c|c|}
\hline Construction & Staple & $\begin{array}{l}\text { Construction } \\
\text { and } \\
\text { Maintenance }\end{array}$ & & 1 & & \\
\hline Construction & Bousillage & $\begin{array}{l}\text { Construction } \\
\text { and } \\
\text { Maintenance }\end{array}$ & & 1 & 373 & $35.3 \%$ \\
\hline Bone & Bone & Food Remains & & 174 & & \\
\hline Shell & Shell & Food Remains & & 75 & & \\
\hline Eggshell & Eggshell & Food Remains & & 216 & & \\
\hline Plant Remains & Plants & Food Remains & & 35 & 500 & $47.3 \%$ \\
\hline Gun Parts & Gun Flint & $\begin{array}{l}\text { Hunting/Wea } \\
\text { ponry }\end{array}$ & & 4 & & \\
\hline Gun Parts & Lead Shot & $\begin{array}{l}\text { Hunting/Wea } \\
\text { ponry }\end{array}$ & & 1 & 5 & $0.5 \%$ \\
\hline Metal & Straight Pin & Sewing & & 1 & 1 & $0.1 \%$ \\
\hline Gastrolith & Gastrolith & $\begin{array}{l}\text { Domestic } \\
\text { Fowl } \\
\text { Production }\end{array}$ & & 10 & 10 & $0.9 \%$ \\
\hline $\begin{array}{l}\text { Refined White } \\
\text { Earthenware }\end{array}$ & $\begin{array}{l}\text { Unidentifie } \\
\text { d }\end{array}$ & Unidentified & 1 & 1 & & \\
\hline $\begin{array}{l}\text { Coarse Red } \\
\text { Earthenware }\end{array}$ & $\begin{array}{l}\text { Unidentifie } \\
\mathrm{d}\end{array}$ & Unidentified & 1 & 1 & & \\
\hline $\begin{array}{l}\text { Coarse Red } \\
\text { Earthenware }\end{array}$ & $\begin{array}{l}\text { Unidentifie } \\
\mathrm{d}\end{array}$ & Unidentified & 1 & 1 & & \\
\hline Pearlware & $\begin{array}{l}\text { Unidentifie } \\
\text { d }\end{array}$ & Unidentified & 1 & 1 & & \\
\hline Pearlware & $\begin{array}{l}\text { Unidentifie } \\
\text { d }\end{array}$ & Unidentified & 1 & 1 & & \\
\hline Pearlware & $\begin{array}{l}\text { Unidentifie } \\
\mathrm{d}\end{array}$ & Unidentified & 1 & 1 & & \\
\hline Whiteware & $\begin{array}{l}\text { Unidentifie } \\
\mathrm{d}\end{array}$ & Unidentified & 1 & 1 & & \\
\hline Metal & Sheet & Unidentified & & 6 & & \\
\hline Metal & $\begin{array}{l}\text { Metal } \\
\text { Fragments }\end{array}$ & Unidentified & & 91 & 104 & $9.8 \%$ \\
\hline Total(s) & & & 31 & $\begin{array}{l}105 \\
7 \\
\end{array}$ & 1057 & $100.0 \%$ \\
\hline
\end{tabular}

A-5. Functional Categories associated with Gender for both the Main House and Outbuilding 


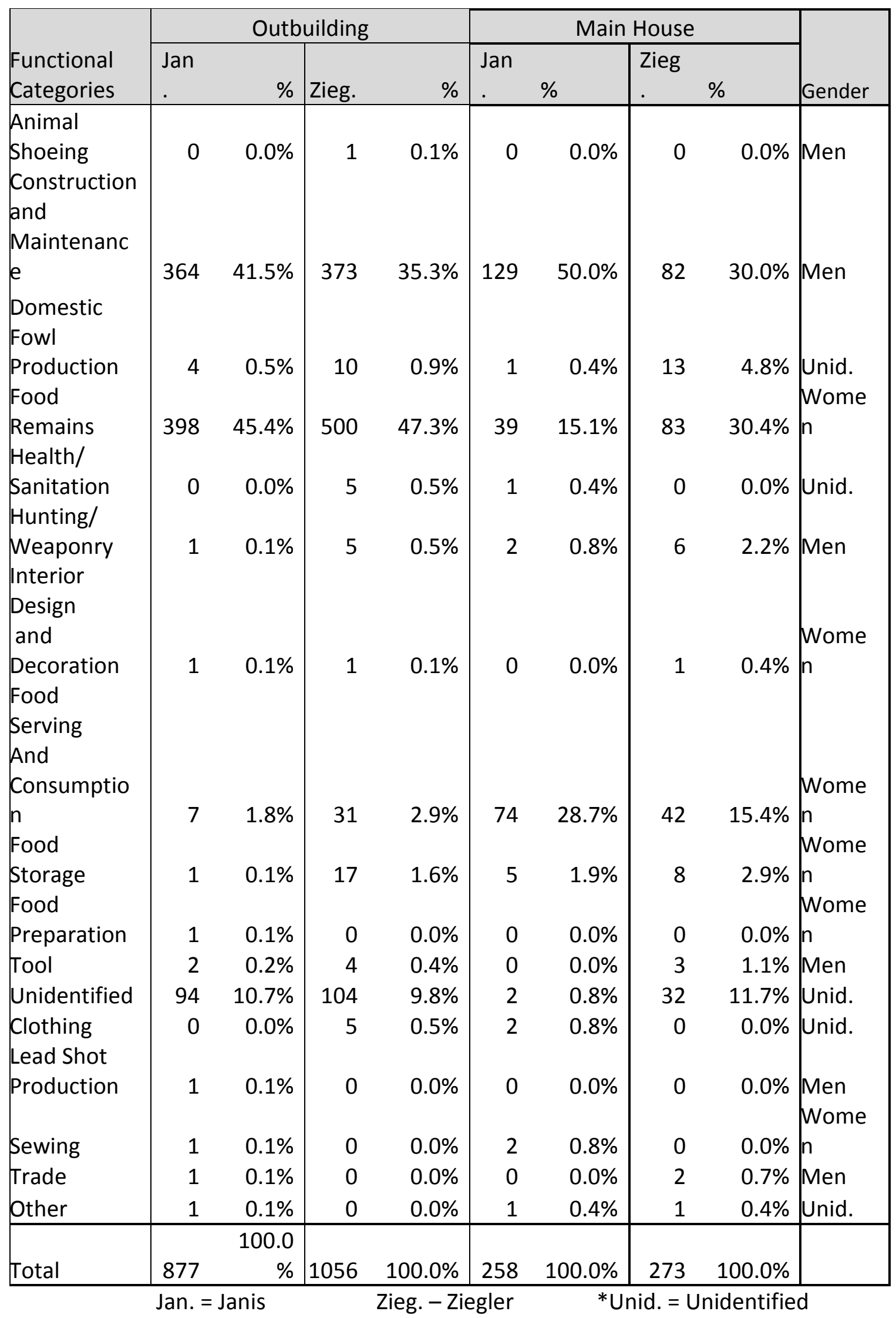


A-6. Food Remains for the Janis and Ziegler Occupations in the Outbuilding

\begin{tabular}{|l|r|r|r|r|}
\hline & Janis & Janis \% & Ziegler & Ziegler \% \\
\hline Bone & 117 & $37.0 \%$ & 174 & $37.4 \%$ \\
\hline Shell & 65 & $20.6 \%$ & 75 & $16.1 \%$ \\
\hline Eggshell & 131 & $41.5 \%$ & 216 & $46.5 \%$ \\
\hline Unidentified Food (probably bone) & 3 & $0.9 \%$ & 0 & $0.0 \%$ \\
\hline Total* & 316 & $100.0 \%$ & 500 & $100.0 \%$ \\
\hline
\end{tabular}

*Total percentage of the food related portions of the assemblage from the outbuilding

A-7. Contingency Table illustrating artifact counts for both occupations in the Outbuilding

\begin{tabular}{|c|c|c|c|}
\hline \multirow{2}{*}{ Artifact type } & Janis & Ziegler & \multirow{2}{*}{ Total } \\
\hline & \# & \# & \\
\hline Ceramic & 18 & 73 & 91 \\
\hline Glass & 5 & 10 & 15 \\
\hline Metal & 86 & 113 & 199 \\
\hline Architectural & 357 & 370 & 727 \\
\hline Plant Remains & 9 & 35 & 44 \\
\hline Animal Remains & 308 & 465 & 773 \\
\hline Gun parts & 2 & 5 & 7 \\
\hline Gastrolith & 5 & 10 & 15 \\
\hline Total & 790 & 1081 & 1871 \\
\hline
\end{tabular}

*Ceramic represented by sherd count

A-8. Contingency Table illustrating artifact percentages for both occupations in the Outbuilding 


\begin{tabular}{|l|r|r|}
\hline \multirow{2}{*}{ Artifact type } & \multicolumn{1}{|l|}{ Janis } & \multicolumn{1}{l|}{ Ziegler } \\
\cline { 2 - 3 } & $\%$ & $\%$ \\
\hline Ceramic & $2.3 \%$ & $6.8 \%$ \\
Glass & $0.6 \%$ & $0.9 \%$ \\
Metal & $10.9 \%$ & $10.5 \%$ \\
Architectural & $45.2 \%$ & $34.2 \%$ \\
Plant Remains & $1.1 \%$ & $3.2 \%$ \\
Animal Remains & $39.0 \%$ & $43.0 \%$ \\
Gun parts & $0.3 \%$ & $0.5 \%$ \\
Gastrolith & $0.6 \%$ & $0.9 \%$ \\
\hline Total & $100.0 \%$ & $100.0 \%$ \\
\hline
\end{tabular}

